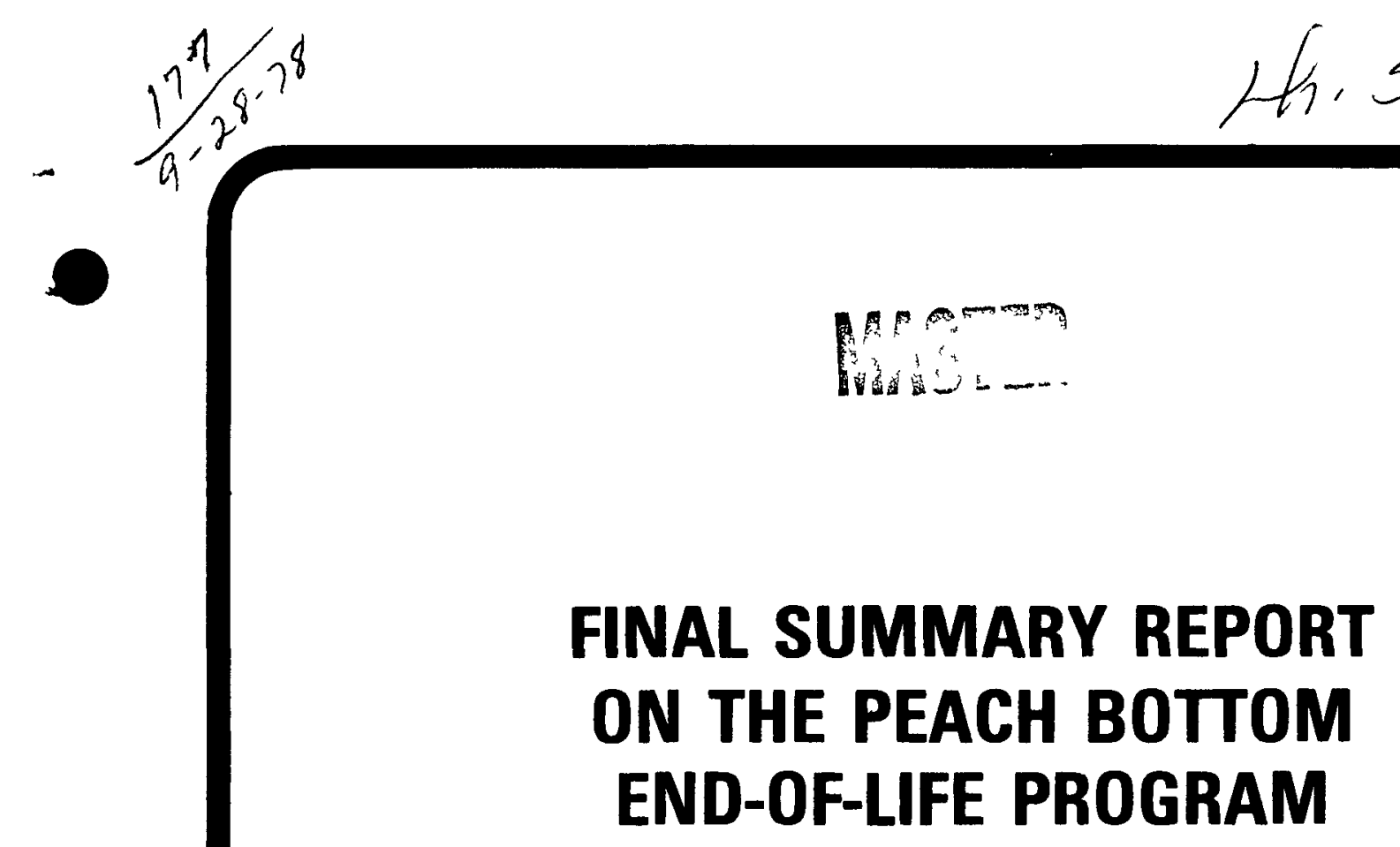

GA-A14404

UC-77

\title{
FINAL SUMMARY REPORT ON THE PEACH BOTTOM END-OF-LIFE PROGRAM
}

\author{
by \\ K. P. STEWARD
}

Prepared under

Contract EY-76-C-03-0167

Project Agreement No. 56

for the San Francisco Operations Office

Department of Energy

DATE PUBLISHED: JULY 1978 


\title{
NOTICE
}

This report was prepared as an account of work sponsored by the United States Government Neither the United States nor the Department of Energy, nor any of their employees, nor any of their contractors, subcontractors, or their employees, makes any warranty, express or implied, or assumes any legal liability or responsibility for the accuracy, completeness or usefulness of any information, apparatus, product or process disclosed, or represents that its use would not infringe privately owned rights

\author{
Printed in the United States of America \\ Available from \\ National Technical Information Service \\ U.S. Department of Commerce \\ 5285 Port Royal Road \\ Springfield, Virginia 22161 \\ Price: Printed Copy $\$ 6.00$; Microfiche $\$ 3.00$
}




\section{DISCLAIMER}

Portions of this document may be illegible in electronic image products. Images are produced from the best available original document. 


\section{DISCLAIMER}

This report was prepared as an account of work sponsored by an agency of the United States Government. Neither the United States Government nor any agency Thereof, nor any of their employees, makes any warranty, express or implied, or assumes any legal liability or responsibility for the accuracy, completeness, or usefulness of any information, apparatus, product, or process disclosed, or represents that its use would not infringe privately owned rights. Reference herein to any specific commercial product, process, or service by trade name, trademark, manufacturer, or otherwise does not necessarily constitute or imply its endorsement, recommendation, or favoring by the United States Government or any agency thereof. The views and opinions of authors expressed herein do not necessarily state or reflect those of the United States Government or any agency thereof. 
GA-A14404

UC-77

\title{
FINAL SUMMARY REPORT ON THE PEACH BOTTOM END-OF-LIFE PROGRAM
}

\author{
by \\ K. P. STEWARD \\ This report was prepared as an account of work
sponsored by the United States Government Netther the
United States nor the United States Department of
Energ, nor any of their employees, nor any of their
contractors, subcontractors, or their employees, makes
any warranty, express or implited, or assumes any legal
lability or responsibutty for the accuracy, completeness
or usefulness of any information, apparatus, product or
process disclosed, or represents that its use would not
infrunge privately owned nghts \\ Prepared under \\ Contract EY-76-C-03-0167 \\ Project Agreement No. 56 \\ for the San Francisco Operations Office \\ Department of Energy
}

\section{GENERAL ATOMIC COMPANY}


$\leftarrow$

a

- 
ABSTRACT

HTGR design methods verifications have been performed under the Peach Bottom End-of-Life Program by comparison of actual with predicted physics, thermal, fission product, and materials behavior in Peach Bottom. These design methods verifications have utilized the data determined from nondestructive fuel and circuit gamma scanning on-site, from laboratory examinations of samples removed from the primary circuit, and from a complementary program of Peach Bottom fuel element postirradiation examinations at Oak Ridge National Laboratory.

Fifty-five driver fuel elements were axially gamma scanned to determine fission product distributions for use in burnup calculations, power profile determinations, and fission product release and redistribution studies. The cesium plateout distribution in the primary circuit was subsequently mapped by gamma scanning the ducting at 12 locations, axially traversing 79 steam generator tubes with $\mathrm{Cd}$ Te detectors from the water side, and internally scanning two vertical runs of ducting.

Component removal involved trepanning of the primary circuit ducting, obtaining access to the steam generator internals, and removing over 100 superheater, evaporator, and economizer tubing samples. During this phase, macroscopic examinations of the steam generator and ducting internals were performed. Subsequent laboratory examinations of removed samples included radiochemical tests to substantiate in-situ gamma scans and to determine Sr-90 distributions; metallurgical tests to evaluate surface films, microstructural changes, and residual mechanical properties; and tritium permeation tests to provide data for improving HTGR tritium release predictions.

The condition and metallurgical integrity of all components examined were found to be excellent, with minimal coolant/substrate interaction and entirely acceptable residual mechanical properties. The suitability of the 
materials used in the construction of the Peach Bottom HTGR was thereby confirmed, verifying the materials design methods used.

Good agreement was found between determined and calculated axial and radial core power distributions, thorium absorption rate profiles, and core average burnup values. The thermal predictive accuracy of $\pm 87^{\circ} \mathrm{C}$ correlated directly with the determined nuclear predictive accuracy of $\pm 10 \%$. Also, both nuclear and thermal predictive accuracies were determined to be well within the limits stated for other nuclear reactor systems.

Very good agreement was found between predicted and measured Core 2 fission gas release and fission product plateout distributions. Large HTGR fission product design methodology in these areas was thereby confirmed. Fission metal release and migration, however, were not well predicted, indicating the need for better physical modeling of Peach Bottom fuel elements and more accurate materials properties data.

In summary, with the exception of fission metal release modeling, where additional work is recommended, very good agreement between predicted and observed behavior in Peach Bottom has been demonstrated, verifying the HTGR design methods used. 


\section{ACKNOWLEDGMENTS}

The technical work under the Peach Bottom End-of-Life Program was performed by the following key contributors at General Atomic:
K. E. Asmussen
W. J. Scheffel
N. L. Baldwin
R. F. Stetson
D. L. Hanson
D. E. Strong
J. F. Holzgraf
C. F. Wallroth
D. I. Roberts
L. Yang
J. J. Saurwein

The assistance and participation in the program of the following additional persons is also gratefully acknowledged:

W. E. Birely (Philadelphia Electric Company)

M. J. Clark (Harwell NRRP, England)

J. V. Iacono (Catalytic, Inc.)

E. J. Kohler (Philadelphia Electric Company)

F. N. Mazandarany (General Electric Company)

R. E. Norman (Oak Ridge National Laboratory)

W. E. Selph (Intelcom Rad Tech Corporation)

R. P. Wichner (Oak Ridge National Laboratory)

This summary report was compiled by the program manager who drew extensively on the detailed technical reports prepared by the above contributors. 
$$
\text { . }
$$ 
CONTENTS

ABSTRACT . . . . . . . . . . . . . . . . . . . . . iii

ACKNOWLEDGMENTS . . . . . . . . . . . . . . . . . . v v

1. INTRODUCTION . . . . . . . . . . . . . . . . . . 1-1

2. PLANT DESCRIPTION AND OPERATIONAL HIGHLIGHTS . . . . . . . . 2-1

2.1. Overview . . . . . . . . . . . . . . . . . 2-1

2.2. P1ant Description . . . . . . . . . . . . . 2-2

2.3. Plant Operational Highlights . . . . . . . . . 2-7

3. NONDESTRUCTIVE TESTING . . . . . . . . . . . . . . 3-1

3.1. Fuel Element Gamma Scanning . . . . . . . . . . 3-1

3.2. Primary Circuit Gamma Scanning . . . . . . . . . 3-8

4. COMPONENT REMOVAL ACTIVITIES ................ . . 4-1

4.1. Component Removal Highlights . . . . . . . . . . . 4-2

5. LABORATORY EXAMINATIONS . . . . . . . . . . . . . . . . 5-1

5.1. Radiochemical Examinations . . . . . . . . . . . 5-1

5.2. Metallurgical Examinations .. . . . . . . . 5-6

5.2.1. Macroscopic Examinations In-Situ ...... . 5-8

5.2.2. Laboratory Examinations of Removed Samples . . 5-9

5.3. Tritium Permeation Tests . . . . . . . . . . 5-17

6. DESIGN METHODS VERIFICATION ............... 6-1

6.1. Nuclear and Thermal Design Methods Verification . . . 6-1

6.1.1. Nuclear Performance Correlations . . . . . . 6-1

6.1.2. Thermal Performance Correlations . . . . . . 6-2

6.2. Fission Product Design Methods Verification . . . . . 6-6

6.2.1. Fission Gas Release Correlations . . . . . . 6-6

6.2.2. Fission Metal Release and Transport Correlations 6-10

6.2.3. Fission Product Plateout Distribution

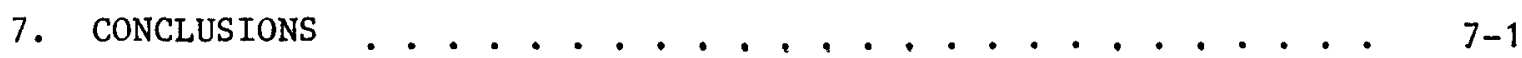

8. REFERENCES . . . . . . . . . . . . . . . 8-1 
FIGURES

1-1. Peach Bottom End-Of-Life Program schedule . . . . . . . . 1-3

2-1. Peach Bottom Atomic Power Station Unit No. 1 . . . . . . 2-3

2-2. Isometric view of reactor as installed in reactor cavity . 2-5

2-3. Peach Bottom fuel element . . . . . . . . . . . . . 2-6

2-4. Simplified process flow diagram for the main coolant system 2-8

3-1. Peach Bottom elements scanned during Phases I and II . . . 3-2

3-2. Test arrangement for gamma scanning Peach Bottom test and driver fuel elements .. . . . . . . . . . . 3-4

3-3. Cs-137 inventory versus axial core position for F03-01 . . 3-6

3-4. Normalized protactinium CPM ratios for E14-01 . . . . . . . 3-7

3-5. Position of detector relative to standard helium duct . . . 3-10

3-6. Peach Bottom HTGR primary coolant system showing gamma scan and trepan sample removal locations . . . . . . . . . . . 3-11

3-7. Cd Te detector positioning apparatus . . . . . . . . . 3-12

3-8. Steam generator tube $\gamma$-scan locations . . . . . . . . . 3-13

3-9. Axial Cs-137 plateout distribution . . . . . . . . . 3-15

3-10. Cs-137 plateout distribution in steam generator superheater 3-16

4-1. Steam generator cross section showing regions of tube sample removal . . . . . . . . . . . . . . . . 4-3

4-2. End-of life component removal schedules . . . . . . . . 4 4-4

4-3. Steam generator tube bundle mockup showing practice tube removal in progress . . . . . . . . . . . . . . 4-6

4-4. Trepan cutting tool mounted on ducting mockup . . . . . . 4-7

4-5. Radiation levels at various locations in the steam

5-1. Diagram of equipment and geometry for gamma scanning of tube samples ... . . . . . . . . . . . . 5 5

5-2. Cesium plateout distribution in Peach Bottom primary circuit .. . . . . . . . . . . . . . 5-5

5-3. Photomicrographs of compact 12 from F03-01 showing the extent of hydrolysis of failed fuel particles . . . . . . . 5-7

5-4. Superheater tubes visible through hole cut through steam generator shell and shroud .. . . . . . . . . . 5-10

5-5. Typical thick multilayered scale present on helium-exposed surfaces of superheater outlet tubes . . . . . . . . 
FIGURES (Continued)

5-6. Superheater bundle . . . . . . . . . . . . . 5-12

5-7. Surface conditions on superheater outlet tube No. 20 . . . 5-13

5-8. Comparison of tensile strength data from superheater tubing with trend bands for solution-annealed Alloy 800 . 5-15

5-9. Comparison of tensile elongation of superheater tubing (archive, inlet, and outlet) with trend bands for solutionannealed Alloy 800 . . . . . . . . . . . . . . 5-16

5-10. Experimental arrangements for the study of tritium permeation through Peach Bottom steam generator tubes . . . . . . . 5-19

5-11. Effect of surface films on tritium permeation rates of Peach Bottom economizer sample EC-0-76 . . . . . . . . 5-20

5-12. Effect of tritium concentration on tritium permeation rate of as-received Peach Bottom superheater sample SU-0-6 . . . 5-21

6-1. Comparison of measured and predicted unrodded axial power profiles for Peach Bottom Core 2. . . . . . . . . . 6-3

6-2. Normalized radial isotope distribution for Peach Bottom Core 2... . . . . . . . . . . . . . . . 6 6-4

6-3. Comparison of calculated and measured temperatures for Peach Bottom driver fuel elements B02-02 and E01-01 . . . . 6-7

6-4. Comparison of measured and calculated fission gas release from Peach Bottom Core 2................ 6-9

6-5. Axial Cs-137 distribution in Peach Bottom E01-01 . . . . . 6-12

6-6. Cs-137 in Peach Bottom compact 28, E01-01 ........ . 6-13

6-7. Sensitivity study on cesium in Peach Bottom E01-01 . . . . 6-14

6-8. Plateout distribution of $\mathrm{Cs}-137$ and $\mathrm{Cs}-134$ in Peach Bottom HTGR . . . . . . . . . . . . . . . . . . 6-17

6-9. Cesium deposition profiles in cold duct . . . . . . . . 6-18

6-10. Cesium profiles determined by internal duct scans . . . . 6-19

TABLES

1-1. Major work items under the Peach Bottom End-of-Life Program 1-2

1-2. Open literature publications under the Peach Bottom End-ofLife Program . . . . . . . . . . . . . . . . . 1-5

2-1. Peach Bottom Unit No. 1 major milestone dates . . . . . . . 2-4

4-1. Peach Bottom HTGR primary coolant system samples shipped to General Atomic . . . . . . . . . . . . . . 4-11 
TABLES (Continued)

5-1. Determination of failed particle fractions in Peach Bottom fuel compacts . . . . . . . . . . . . . . 5-6

5-2. Calculated Peach Bottom tritium release rate . . . . . . 5-22 


\section{INTRODUCTION}

Shutdown of the Peach Bottom Unit No. 1 HTGR in October 1974 provided a unique opportunity for validation of HTGR design methods and codes in a representative HTGR environment over significant operating times. During 1974, a program of end-of-1ife surveillance, testing, and design verification was therefore scoped by General Atomic (GA) and proposed to the USAEC (now DOE) and the Electric Power Research Institute (EPRI). In March 1975, the Peach Bottom End-of-Life (PBEOL) Program was initiated as a $\$ 1.65$ million contract jointly funded by ERDA (DOE) and EPRI.

The prime objective of the PBEOL Program was to verify generic design codes and assumptions by comparison of actual and predicted physics, thermal, fission product, and materials behavior in Peach Bottom. Secondary objectives were (1) to complement previous Peach Bottom surveillance programs and expand the knowledge of operating HTGR behavior, and (2) to improve HTGR licensability by demonstrating conservatisms in HTGR plant and fuel designs.

The design methods verifications utilized the data determined during three consecutive phases of the program together with data determined in a complementary program of Peach Bottom driver fuel element postirradiation Examinations (PIEs) at Oak Ridge National Laboratory (ORNL). The three phases were (1) nondestructive fuel and circuit gamma scanning on-site, (2) on-site inspection and removal of steam generator and primary circuit component samples, and (3) laboratory examinations of removed components. The major work items in each of these phases and the schedules associated with each are shown in Table 1-1 and Fig. 1-1, respectively.

The program included major subcontracts to Intelcom Rad Tech (IRT) Corporation for gamma scanning and to Catalytic, Incorporated for component 
TABLE 1-1

MAJOR WORK ITEMS UNDER THE PEACH BOTTOM END-OF-LIFE PROGRAM

Nondestructive testing (on-site)

Fuel gamma scanning - Phase $2^{(a)}$

Circuit gamma scanning - Phase 1

Circuit gamma scanning - Phase 2

Macroexamination of steam generator and ducting internals

Component removal

Ducting sample removal

Steam generator sample removal

Laboratory examinations

Radiochemical examinations

Metallurgical examinations

Tritium permeation tests

Design methods verifications (DMV)

Nuclear physics DMV

Therma1 DMV

Fission products DMV

Materials performance

Documentation

Data compilation and final reports

Peach Bottom operating history report

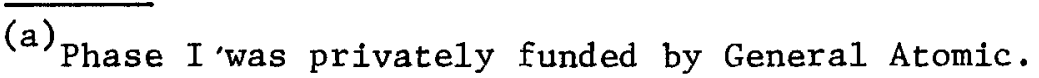




\begin{tabular}{|l|l|l|l|l|}
\hline & 1975 & 1976 & 1977 \\
\hline A. NONDESTRUCTIVE TESTING \\
1. FUEL GAMMA SCANNING - PHASE 2 \\
2. PRIMARY CIRCUIT GAMMA SCANNING \\
$\begin{array}{l}\text { PHASES 1 AND 2 } \\
\text { 3. MACROEXAMINATIONS (ON-SITE) }\end{array}$ \\
B. COMPONENT REMOVAL \\
C. EXAMINATIONS OF REMOVED SAMPLES \\
1. RADIOCHEMICAL EXAMINATIONS \\
2. METALLURGICAL EXAMINATIONS \\
3. TRITIUM PERMEATION TESTS \\
D. DESIGN METHODS VERIFICATIONS (DMV)** \\
1. NUCLEAR AND THERMAL DMV \\
2. FISSION PRODUCT DMV \\
E. DOCUMENTATION
\end{tabular}

*-_- PLANNING, TEST SPECIFICATION PREPARATION, ETC.

ON-SITE OR LABORATORY WORK

-. D. DATA ANALYSIS AND REPORTING

** NOTE: VERIFICATION OF MATERIALS SUITABILITY AND PERFORMANCE IS INCLUDED UNDER C.2

*** CONTRACT END DATE 6/30/78.

Fig. 1-1. Peach Bottom End-Of-Life Program schedule 
sample removal. On-site services were provided by Philadelphia Electric Company, and on-site work was closely coordinated with Peach Bottom decommissioning activities. The program work scope included preparation of a detailed operating history report for the Peach Bottom HTGR (Ref. 1). Also, Harwel1 Atomic Energy Research Establishment performed fission product studies on removed samples at no cost to the program.

On-site activities commenced with fuel gamma scanning for long-lived isotopes in May 1975. Phase I circuit gamma scanning was performed on-site between July and September 1975; Phase 2 was performed in January 1976 during component removal (October 1975 through February 1976). Subsequent laboratory testing continued through May 1977. Design methods verifications were ongoing from the time of initial on-site data acquisition until May 1978.

All work under the program has now been documented in detail as indicated in Table 1-2. This final report therefore serves to summarize the work scopes, activities, and results for each work area; to present an overview of the program; and to include by reference all detailed documentation related to the PBEOL Program.

To provide appropriate orientation for the reader, a brief description of the Peach Bottom HTGR, the core and fuel element design, and the highlights of the plant operation are included in Section 2. Work under each of the major phases of the program is covered in Sections 3 through 6 . 
TABLE 1-2

OPEN LITERATURE PUBLICATIONS UNDER THE PEACH BOTTOM END-OF-LIFE PROGRAM

\begin{tabular}{|c|c|c|c|}
\hline Title & Author (s) & Identity & Date Pub1ished \\
\hline $\begin{array}{l}\text { Operating History Report for the Peach Bottom } \\
\text { HTGR, Vols. I and II }\end{array}$ & $\begin{array}{l}\text { W. J. Scheffel } \\
\text { N. L. Baldwin } \\
\text { R. W. Tomlin }\end{array}$ & GA-A 13907 & August 1976 \\
\hline $\begin{array}{l}\text { Measurement of Fission Product Activity in } \\
\text { the Peach Bottom Reactor Primary Coolant Loop }\end{array}$ & $\begin{array}{l}\text { Intelcom Rad } \\
\text { Tech Corp. }\end{array}$ & GA-A 14059 & August 1976 \\
\hline Peach Bottom End-of-Life Study & J. F. Kendall (EPRI) & EPRI Journal & October 1976 \\
\hline $\begin{array}{l}\text { Gamma Scanning the Primary Circuit of the } \\
\text { Peach Bottom HTGR }\end{array}$ & $\begin{array}{l}\text { D. L. Hanson } \\
\text { N. L. Baldwin } \\
\text { W. E. Selph }\end{array}$ & $\begin{array}{l}\text { GA-A } 14161 \text { and } \\
\text { ANS Transactions }\end{array}$ & $\begin{array}{l}\text { October } 1976 \\
\text { November } 1976\end{array}$ \\
\hline $\begin{array}{l}\text { Removal of Primary Circuit Components from } \\
\text { the Peach Bottom HTGR }\end{array}$ & Catalytic, Inc. & GA-A14369 & April 1977 \\
\hline $\begin{array}{l}\text { Study of Tritium Permeation Tests on Peach } \\
\text { Bottom Steam Generator Tubes }\end{array}$ & $\begin{array}{l}\text { L. Yang } \\
\text { W. A. Baugh } \\
\text { N. L. Baldwin }\end{array}$ & GA-A 14376 & June 1977 \\
\hline $\begin{array}{l}\text { Peach Bottom Decommissioning and Component } \\
\text { Removal }\end{array}$ & $\begin{array}{l}\text { E. J. Kohler (PE) } \\
\text { K. P. Steward } \\
\text { J. V. Iacono (Catalytic) }\end{array}$ & $\begin{array}{l}\text { GA-A } 14297 \text { and } \\
\text { ANS Transactions }\end{array}$ & $\begin{array}{l}\text { August } 1977 \\
\text { August } 1977\end{array}$ \\
\hline $\begin{array}{l}\text { Metallurgical Examination of Primary Circuit } \\
\text { Components from the Peach Bottom HTGR }\end{array}$ & D. I. Roberts et al. & GA-A14506 & February 1978 \\
\hline $\begin{array}{l}\text { Gamma Spectroscopic Examination of Peach } \\
\text { Bottom HTGR Core Components }\end{array}$ & $\begin{array}{l}\text { J. F. Holzgraf } \\
\text { F. McCord } \\
\text { C. F. Wallroth }\end{array}$ & GA-A13453 & April 1978 \\
\hline $\begin{array}{l}\text { Gamma Spectroscopic Examination of the Peach } \\
\text { Bottom HTGR Core }\end{array}$ & $\begin{array}{l}\text { C. F. Wallroth } \\
\text { J. F. Holzgraf }\end{array}$ & $\begin{array}{l}\text { GA-A } 14855 \text { and } \\
\text { ANS Transactions }\end{array}$ & $\begin{array}{l}\text { April } 1978 \\
\text { June } 1978\end{array}$ \\
\hline
\end{tabular}


TABLE 1-2 (Continued)

\begin{tabular}{|c|c|c|c|}
\hline Title & Author (s) & Identity & Date Published \\
\hline $\begin{array}{l}\text { Nuclear and Thermal Design Verification for the } \\
\text { Peach Bottom High-Temperature Gas-Cooled } \\
\text { Reactor }\end{array}$ & $\begin{array}{l}\text { J. J. Saurwein } \\
\text { C. F. Wallroth }\end{array}$ & GA-A14726 & July 1978 \\
\hline $\begin{array}{l}\text { HTGR Nuclear and Thermal Design Verification } \\
\text { in Peach Bottom }\end{array}$ & $\begin{array}{l}\text { C. F. Wallroth } \\
\text { J. J. Saurwein }\end{array}$ & $\begin{array}{l}\text { GA-A } 14725 \text { and } \\
\text { ANS Transactions }\end{array}$ & $\begin{array}{l}\text { April } 1978 \\
\text { June } 1978\end{array}$ \\
\hline $\begin{array}{l}\text { Fission Gas Release from Core } 2 \text { of the Peach } \\
\text { Bottom HTGR }\end{array}$ & $\begin{array}{l}\text { D. L. Hanson } \\
\text { N. L. Baldwin }\end{array}$ & ANS Transactions & June 1978 \\
\hline $\begin{array}{l}\text { Radiochemical Examination of Peach Bottom } \\
\text { HTGR Components }\end{array}$ & $\begin{array}{l}\text { N. L. Baldwin } \\
\text { B. L. Norman } \\
\text { W. E. Bell }\end{array}$ & GA-A14495 & July 1978 \\
\hline $\begin{array}{l}\text { Final Report on HTGR Design Verification } \\
\text { under the Peach Bottom End-of-Life Program }\end{array}$ & K. P. Steward & GA-A14404 & July 1978 \\
\hline $\begin{array}{l}\text { Fission Product Design Verification in } \\
\text { the Peach Bottom HTGR }\end{array}$ & $\begin{array}{l}\text { D. L. Hanson } \\
\text { D. E. Strong }\end{array}$ & $\mathrm{GA}-\mathrm{A} 15022$ & To be published \\
\hline $\begin{array}{l}\text { The Desorption of Cesium from Peach Bottom } \\
\text { HTGR Steam Generator Materials }\end{array}$ & M. J. Clarke & $\begin{array}{l}\text { Harwel1 AERE- } \\
\text { R-8949 }\end{array}$ & To be published \\
\hline
\end{tabular}

Fina1 Report on HTGR Design Verification

Fission Product Design Verification in the Peach Bottom HTGR

D. E. Strong

Harwel1 AERE$\mathrm{R}-8949$ 
2. PLANT DESCRIPTION AND OPERATIONAL HIGHLIGHTS

\subsection{OVERVIEW}

The Peach Bottom Atomic Power Station Unit No. 1 was the first installation of an HTGR in the United States. Power operation began in January 1967 and commercial operation on June 1, 1967. The plant was operated successfully through October 31, 1974 when it was shut down for decommissioning. The Peach Bottom nuclear steam supply (NSS) system, designed and supplied by GA, generated more than 3.72 million $M W(t)-h r$ and 1.38 million gross MW(e)-hr for an average gross plant thermal efficiency of $37.2 \%$. The Peach Bottom NSS produced $538^{\circ} \mathrm{C}$ superheated steam at a pressure of $10 \mathrm{MPa}$ (1450 psi) with an overall lifetime availability of $88 \%$. The plant produced over 1.2 million MW(e)-hr for the Philadelphia Electric Company grid over a lifetime of 1349 equivalent full power days (EFPDs), with a gross plant capacity factor of $74 \%$.

In addition to producing commercial power, Peach Bottom was a prototype nuclear power station. This status required that power changes, including shutdowns, be performed to accommodate testing of plant systems and components under the USAEC (now DOE) sponsored postconstruction research and development program. Such surveillance programs to monitor core component performance, fission product release and plateout, circulating activity, coolant chemistry, and other important features of reactor operation were continued throughout reactor 1 ifetime by GA and ORNL. In addition, during the operation of Core 2, 33 fuel test elements were installed and irradiated as part of a fuel testing program for advanced HTGRs.

A brief description of the Peach Bottom HTGR, some further details of operating experience, and the reasons for decommissioning the reactor are presented below. 


\subsection{PLANT DESCRIPTION}

Peach Bottom Atomic Power Station Unit No. 1, owned and operated by the Philadelphia Electric Company, was a 40-MW(e) HTGR demonstration plant situated 80 miles southwest of Philadelphia on the Susquehanna River (Fig. 2-1). The NSS system was designed, developed, and supplied by GA and the engineer-constructor was the Bechtel Corporation. Financing was provided by the High-Temperature Reactor Development Associates, a nonprofit organization composed of 53 investor-owned utilities from throughout the United States and by the USAEC (nOw DOE) as part of the power reactor demonstration program. The significant milestone dates for the Peach Bottom HTGR are shown in Table 2-1.

The heart of the Peach Bottom NSS system was a helium-cooled, graphitemoderated, 115-MW(t) reactor core operating at high temperature on a thorium-uranium fuel cycle (Fig. 2-2). The reactor core consisted of 804 graphitic fuel elements oriented vertically in a closely packed circular pattern within the reactor vessel. Each fuel element contained 30 annular fuel compacts (Fig. 2-3) comprised of fuel particles in a graphite matrix material. The kernels in the fuel particles were mixed thorium - highly enriched uranium carbide. Core 1 fuel particles were coated with a single layer of pyrolytic carbon solely to prevent hydrolysis during manufacture. The improved BISO coatings on the Core 2 fuel particles were designed also to retain fission products during the life of Core 2 .

Radloactivity in the main coolant system was controlled by drawing a purge stream of main coolant helium over the fuel compacts inside the lowpermeability graphite sleeves to the external fission product trapping system. This system consisted of a series of low-temperature delay beds and fission product traps to remove and permit decay of fission products. A dehydrator, an oxidizer, and a liquid-nitrogen-cooled charcoal trap removed moisture, chemical impurities, and the long-1ived $\mathrm{Kr}-85$ from the main coolant system. 


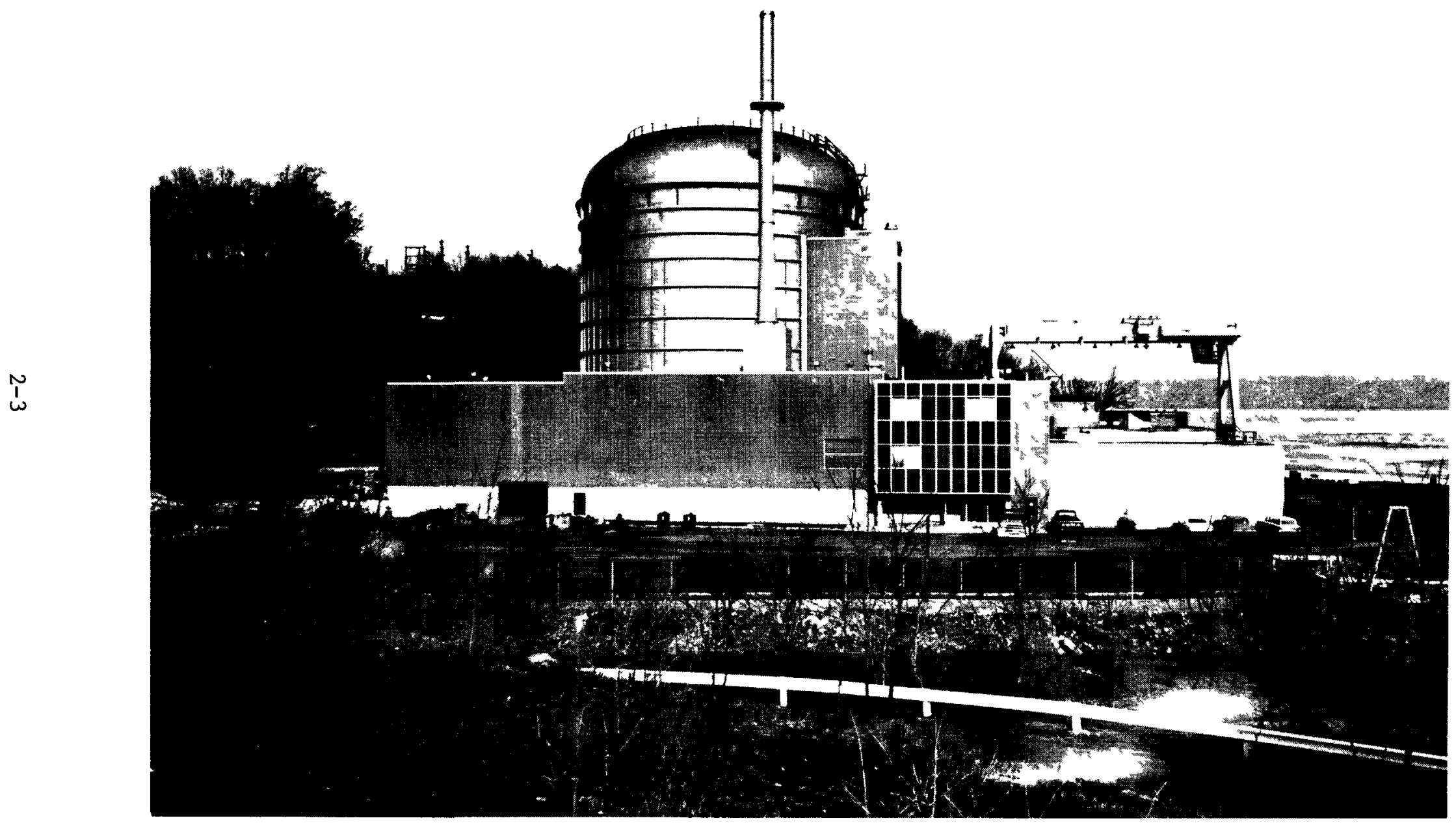

HT33349

Fig. 2-1. Peach Bottom Atomic Power Station Unit No. 1 
TABLE 2-1

PEACH BOTTOM UNIT NO. 1 MAJOR MILESTONE DATES

$\begin{array}{ll}\text { August 1959 } & \begin{array}{l}\text { Contracts signed - USAEC, Philadelphia } \\ \text { Electric, General Atomic }\end{array} \\ \text { February 1962 } & \text { Construction permit issued } \\ \text { January 1964 } & \text { Vessel shipment to site } \\ \text { January 1965 } & \text { Fuel shipment to site } \\ \text { January 1966 } & \text { License for 1-MW(t) operation received } \\ \text { February 1966 } & \text { Start of fuel loading } \\ \text { March 1966 } & \text { Initial criticality } \\ \text { April 1966 } & \text { Core 1 1oading completed } \\ \text { May 1966 } & \text { Low-power testing completed } \\ \text { January 1967 } & \text { Full-power 11cense 1ssued } \\ \text { May 1967 } & \text { Full power reached } \\ \text { June 1967 } & \text { Start of commercial operation for Core } 1 \\ \text { October 1969 } & \text { Shutdown for refueling } \\ \text { July 1970 } & \text { Start of commercial operation for Core } 2 \\ \text { October 1974 } & \begin{array}{l}\text { Core 2 end-of-life, plant shutdown for } \\ \text { decommissioning }\end{array}\end{array}$




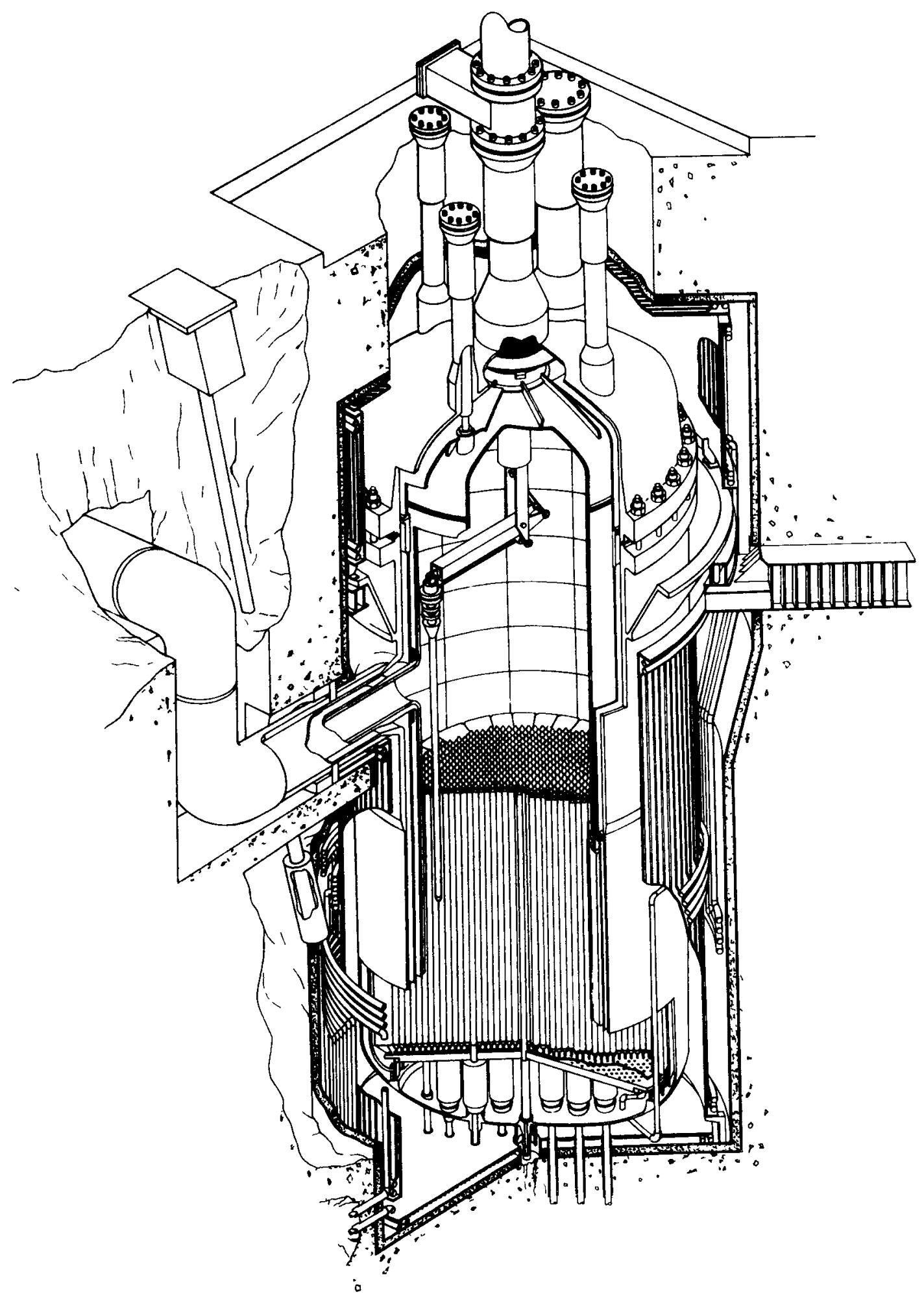

Fig. 2-2. Isometric view of reactor as installed in reactor cavity 


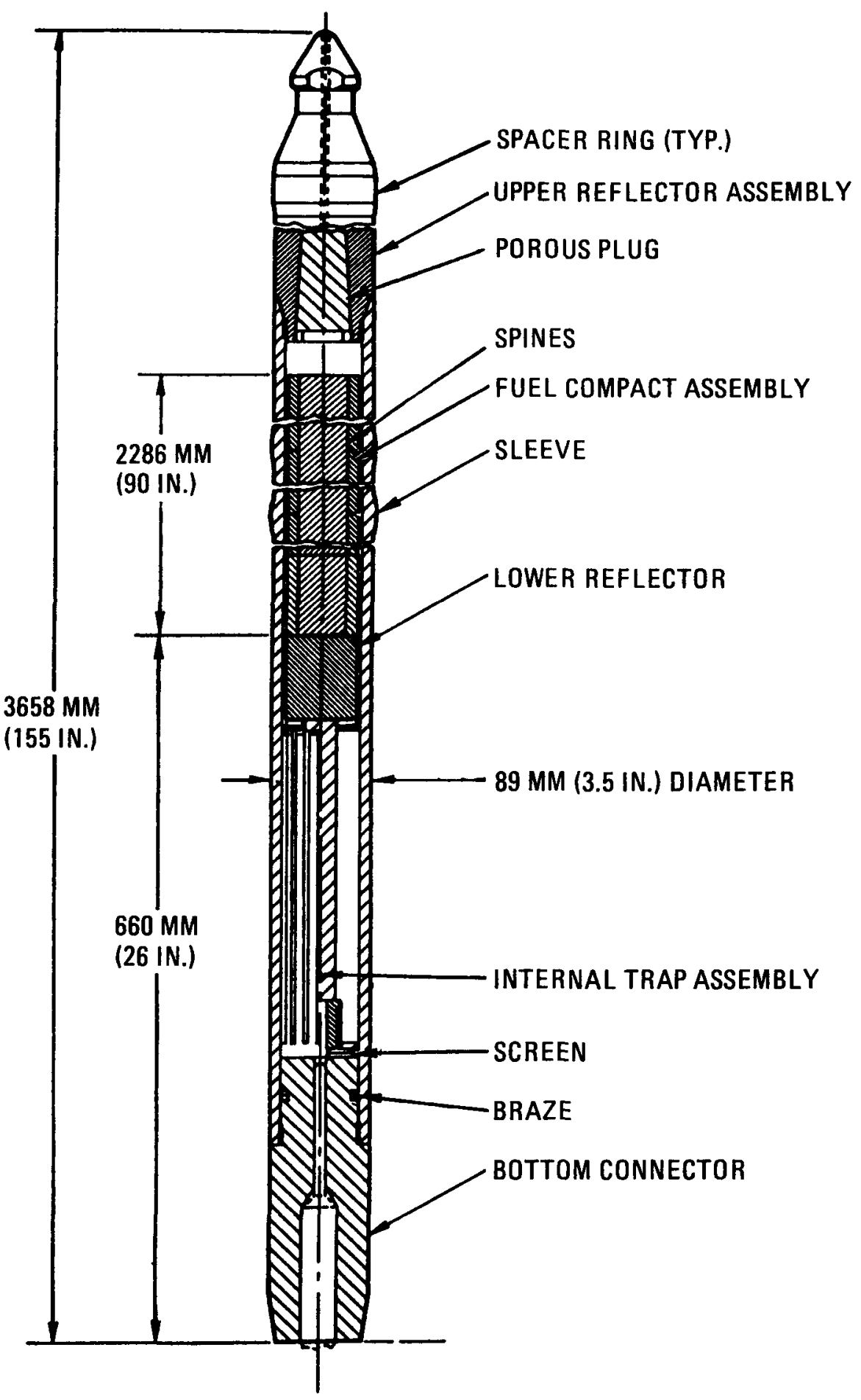

Fig. 2-3. Peach Bottom fuel element 
Upon exit from the upper core plenum, the coolant flow was split between two parallel loops as shown in Fig. 2-4. Centrifugal compressors forced the reactor outlet gas at approximately $700^{\circ} \mathrm{C}$ through the steam generators, where it was cooled to about $330^{\circ} \mathrm{C}$ before it entered the circulators for return to the core. The steam generators were forcedrecirculation drum-type boilers having pendant U-tube superheater, evaporator, and economizer sections. The superheater tubes were made of Incoloy 800 and the other sections were carbon steel. The primary pressure boundary was also fabricated of carbon steel. The hot gas was contained inside concentric ducting or shrouds insulated with metallic thermal barrier to keep the steel temperatures within acceptable limits.

The plant was designed to produce $40 \mathrm{MW}(\mathrm{e})$ net maximum and could follow load automatically down to $30 \%$ at rates in excess of $3 \% / \mathrm{min}$. Thermal efficiency at the design operating conditions was approximately $39 \%$ which represented the highest efficiency achieved by any nuclear power plant operated in the United States at that time.

\subsection{PLANT OPERATIONAL HIGHLIGHTS}

The Peach Bottom fuel cycle concept was based on continuous operation with a core of 804 fuel elements until the end-of-life (approximately 900 ful1-power days), at which time the entire core would be replaced with a new core. Peach Bottom operated with Core 1 until October 1969 accumulating 452 EFPDs, at which time the plant was shut down for installation of a second core of 804 fuel elements. This premature installation of a second core was necessitated by the development of cracks in the graphite sleeves surrounding the fuel compacts of 90 of the fuel elements. The cracked sleeves were caused by swelling of the fuel compacts as a result of irradiation-induced dimensional changes in the monolayer coatings on the fuel particles.

The existence of cracked elements was detected by an increase in circulating primary coolant activity, which eventually reached a level of 


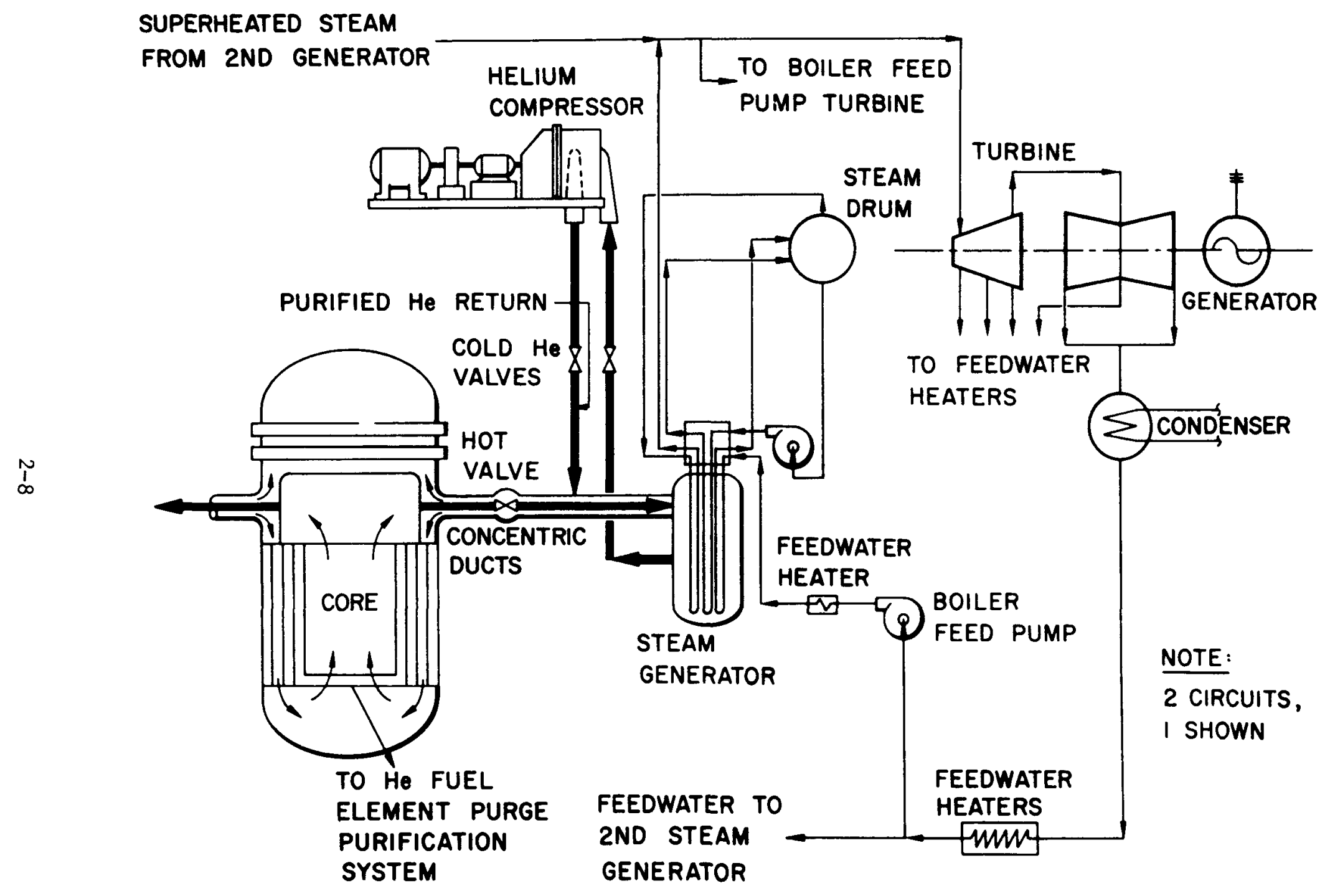

Fig. 2-4. Simplified process flow diagram for the main coolant system 
$270 \mathrm{Ci}$. Although this activity level was well below design activity of $4225 \mathrm{Ci}$, it was considered prudent to replace the core in view of the accelerating rate of fuel element cracking. It is important to note, however, that the increase in primary system activity did not result in significant increase in radiation levels within the plant, nor in an increase of gaseous and liquid radioactive waste activity released to the environment.

Core 2, containing improved BISO coated fuel particles, was inserted into the reactor in early 1970. The design of this new coated fuel particle was characterized by (1) a greater retention of fission products, and (2) excellent irradiation stability of the fuel coating thus preventing fuel compact expansion. The new fuel particle was coated with a double layer of pyrolytic carbon (BISO) consisting of an inner low-density carbon coating and an outer high-density carbon coating. The primary circuit activity never exceeded $1 \mathrm{Ci}$ during the entire Core 2 lifetime of 900 EFPDs, and the low fission gas release into the purge stream demonstrated the improved fission product retention characteristics of the Core 2 fuel particles.

Other major accomplishments at Peach Bottom Unit 1 included the following:

1. Excellent agreement was found between predicted and actual core physics characteristics throughout reactor operation, thus verifying the methods used.

2. The reactor control system functioned exceptionally well and received commendation from Philadelphia Electric operators.

3. The steam generators operated throughout plant lifetime without tube leaking or plugging. 
4. The performance of almost all reactor systems was without major problems, verifying the design philosophy of many areas used in Fort St. Vrain and larger HTGRs.

5. Philadelphia Electric operated the plant in a load-following manner during the majority of its 7-year lifetime, demonstrating the ability of the HTGR to function in this manner.

6. The station availability, excluding planned shutdowns for R\&D programs during the reactor lifetime, was $88 \%$. This compares very favorably with the best performances of fossil-fired and nuclear plants.

The decision to shut down and decommission the Peach Bottom HTGR was based upon several factors. First, the major objective of the plant to demonstrate the technical feasibility and commercial operation of an HTGR had been successfully achieved. Second, the evolution of the HTGR was to be continued in the Fort St. Vrain plant, which is currently in the startup phase. Third, the size of the plant made it uneconomical to operate relative to Peach Bottom Units 2 and 3 [1060 MW(e)]. Finally, major retrofitting of the plant would have been required to meet revised safety criteria for continued operation. A minimum decommissioning was therefore decided upon and implemented as discussed in Refs. 2 and 3.

The following sections present an overview of on-site gamma scanning and component removal work, subsequent laboratory examinations of removed samples, and the design methods verifications performed under the PBEOL Program. 


\section{NONDESTRUCTIVE TESTING}

The initial activities under the PBEOL Program involved nondestructive fuel element and primary circuit gamma scanning at the Peach Bottom site. Data acquisition was performed by IRT Corporation under subcontract to GA, and on-site services were provided by Philadelphia Electric Company.

\subsection{FUEL ELEMENT GAMMA SCANNING}

Gamma scanning of 55 driver fuel elements, 21 fuel test elements, 3 reflector elements, and a control rod and sleeve was performed on-site in two phases. The first scanning operation took place shortly after reactor shutdown to measure short-half-lived isotopes; the second phase took place in June 1975 to detect long-lived isotopes. Phase I was privately funded by GA and Phase 2 was performed under the PBEOL Program. Core locations of elements scanned in the two phases are shown in Fig. 3-1.

The objective of the fuel element gamma scanning was to provide basic information for comparison with design predictions. Specific objectives were:

1. To provide axial and radial distributions of fission products in the core for subsequent nuclear design verifications.

2. To determine $\mathrm{Cs}-137$ inventories as input to relative and absolute fuel burnup calculations.

3. To evaluate fission product distributions in fuel elements. 


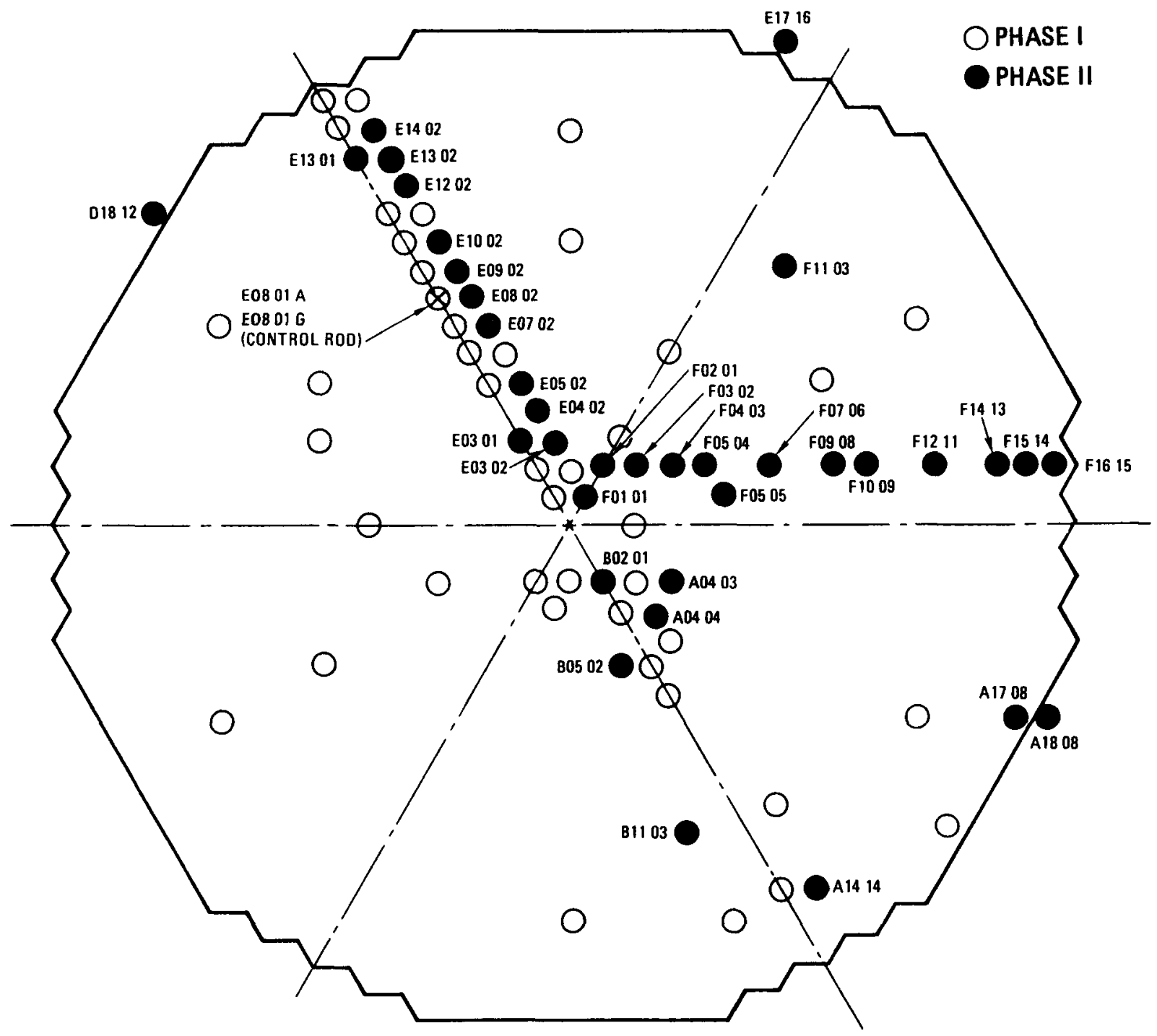

Fig. 3-1. Peach Bottom elements scanned during Phases I and II 
4. To assess axial and radial thorium absorption rates near end-oflife (EOL) by monitoring Pa-233 distribution.

5. To determine fuel column length changes during irradiation.

The general arrangement of the gamma scanning equipment at Peach Bottom is outlined in Fig. 3-2. The major components were a collimator, a charge machine, a Ge(Li) gamma spectrometer, and associated electronic data acquisition equipment. The charge machine driver mechanism was modified to slow movement of the element past the collimator slit (Fig. 3-2) and gamma rays passing through the slit were monitored using a lead-encased high-resolution $\mathrm{Ge}(\mathrm{Li})$ detector. The signal from the detector was transmitted to a pulse height multichannel analyzer (MCA) and a series of single-channel analyzers. The MCA-accumulated gamma ray spectra were stored on magnetic tape for subsequent computer analysis and data processing at $\mathrm{GA}$.

Ten different isotopes were monitored to establish the types of information indicated below:

\begin{tabular}{ll}
\multicolumn{1}{c}{ Isotope } & \multicolumn{1}{c}{ Application } \\
Cs-137 (absolute inventory) & Composite FIMA* and Cs-137 loss \\
$\begin{array}{l}\text { La-140 (relative) } \\
\text { Zr-95 (relative) }\end{array}$ & $\begin{array}{l}\text { Normalized power distribution for 1ast } \\
50 \text { to } 200 \text { days of reactor operation }\end{array}$ \\
Cs-137 (relative) & $\begin{array}{l}\text { Normalized time-averaged power } \\
\text { distribution }\end{array}$ \\
Cs-137/Cs-134 (relative) & $\begin{array}{l}\text { Normalized time-averaged thermal } \\
\text { fluence distribution }\end{array}$ \\
Pa-233 (relative) & $\begin{array}{l}\text { Normalized Th-232 absorption rates } \\
\text { Cs-137/Zr-95 (ratio)** }\end{array}$ \\
& $\begin{array}{l}\text { Fission product release and redistri- } \\
\text { bution within the element }\end{array}$
\end{tabular}

*Fissions per initial metal atom.

$* * \mathrm{Ce}-141, \mathrm{Ce}-144, \mathrm{I}-131$, and $\mathrm{Ru}-103$ were also monitored in a similar manner. 


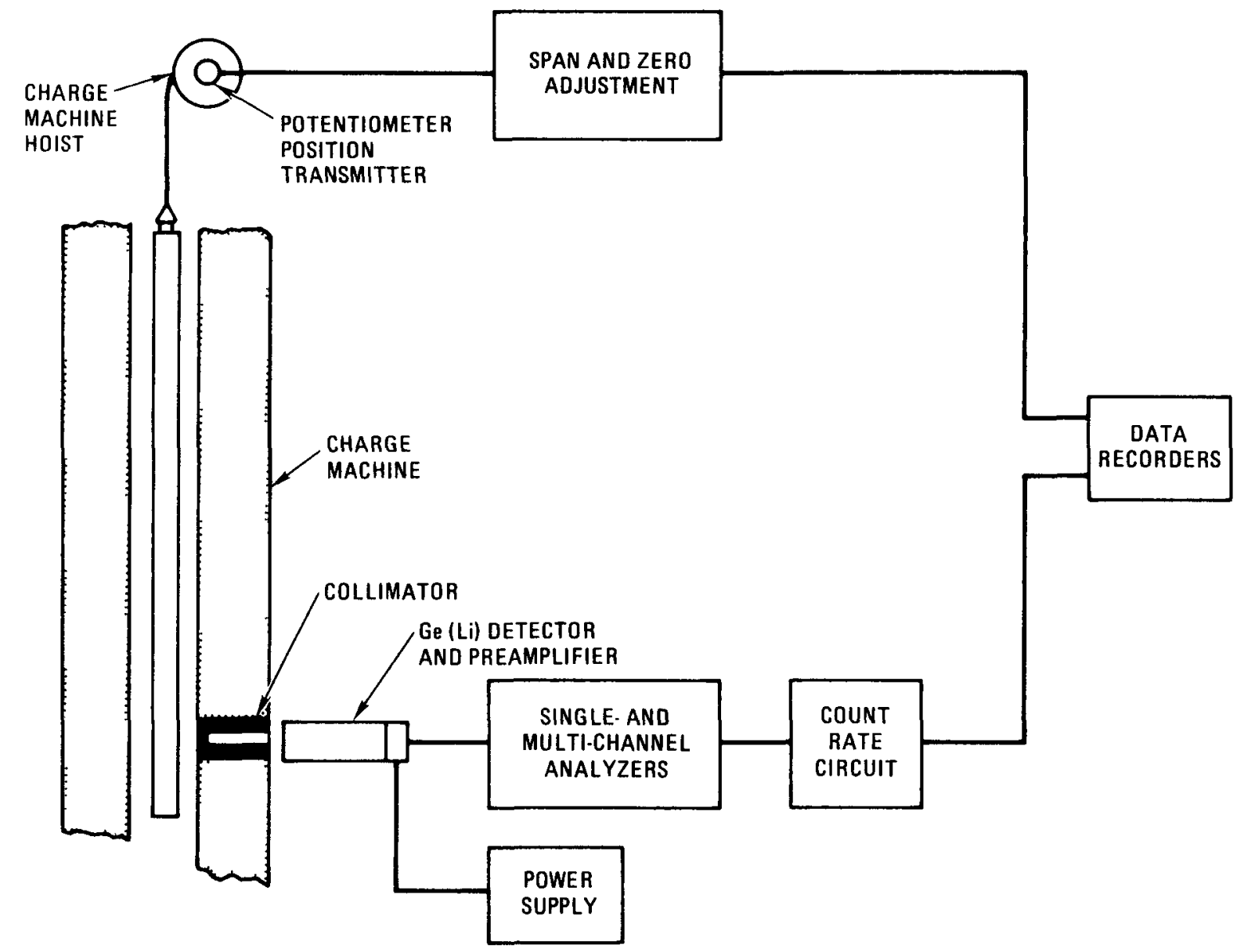

Fig. 3-2. Test arrangement for gamma scanning Peach Bottom test and driver fuel elements 
Selected results illustrating Cs redistribution in hotter elements and the comparison between predicted thorium absorption rates and measured normalized $\mathrm{Pa}-233$ distributions are shown in Figs. 3-3 and 3-4, respectively. Comparisons between measured and predicted axial and radial power profiles are shown and discussed under nuclear physics design verification in Section 6.1.

The major results and conclusions from the fuel element gamma scans were as follows:

1. Normalized axial and radial Cs-137, La-140, and $\mathrm{Zr}-95$ profiles in the core were successfully determined from Phase 1 and 2 gamma scans. The Cs-137 profiles were subsequently shown to be in good agreement with predicted axial and radial time-averaged power distributions. Also, La-140 and Zr-95 profiles predicted corresponding power profiles at EOL reasonably well (see Section $6.1)$.

2. Of the isotopes analyzed, only Cs-137 and Cs-134 were found to migrate and redistribute within the hotter elements (Fig. 3-3). There was no detectable release from the fuel elements scanned within the measurement uncertainties.

3. Cesium inventory measurements resulted in agreement with predictions within $\pm 0.4 \%(1 \sigma)$ on a core average basis and within $\pm 6.6 \%$ on an element-to-element basis. Good agreement was found between GA and ORNL inventory measurements for selected elements.

4. Core average burnup calculated from Cs-137 inventory measurements agreed within $\pm 0.7 \%(1 \sigma)$ with GAUGE code predictions; similar comparisons were within $\pm 6.8 \%$ on an element-to-element basis.

5. The Pa-233 normalized activity profile was found to follow the predicted GAUGE/FEVER thorium absorption profiles (Fig. 3-4). 


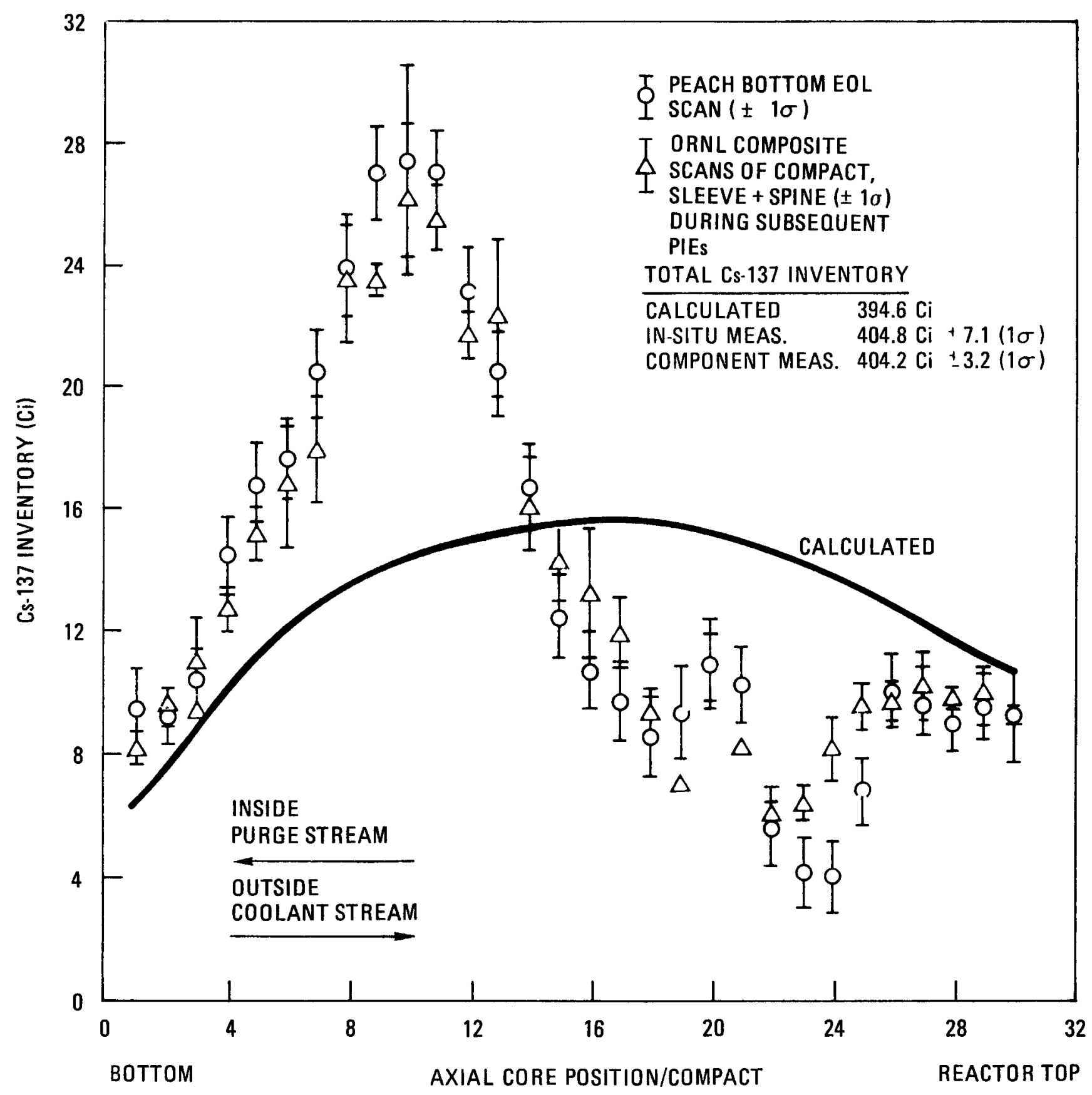

Fig. 3-3. Cs-137 inventory versus axial core position for F03-01 


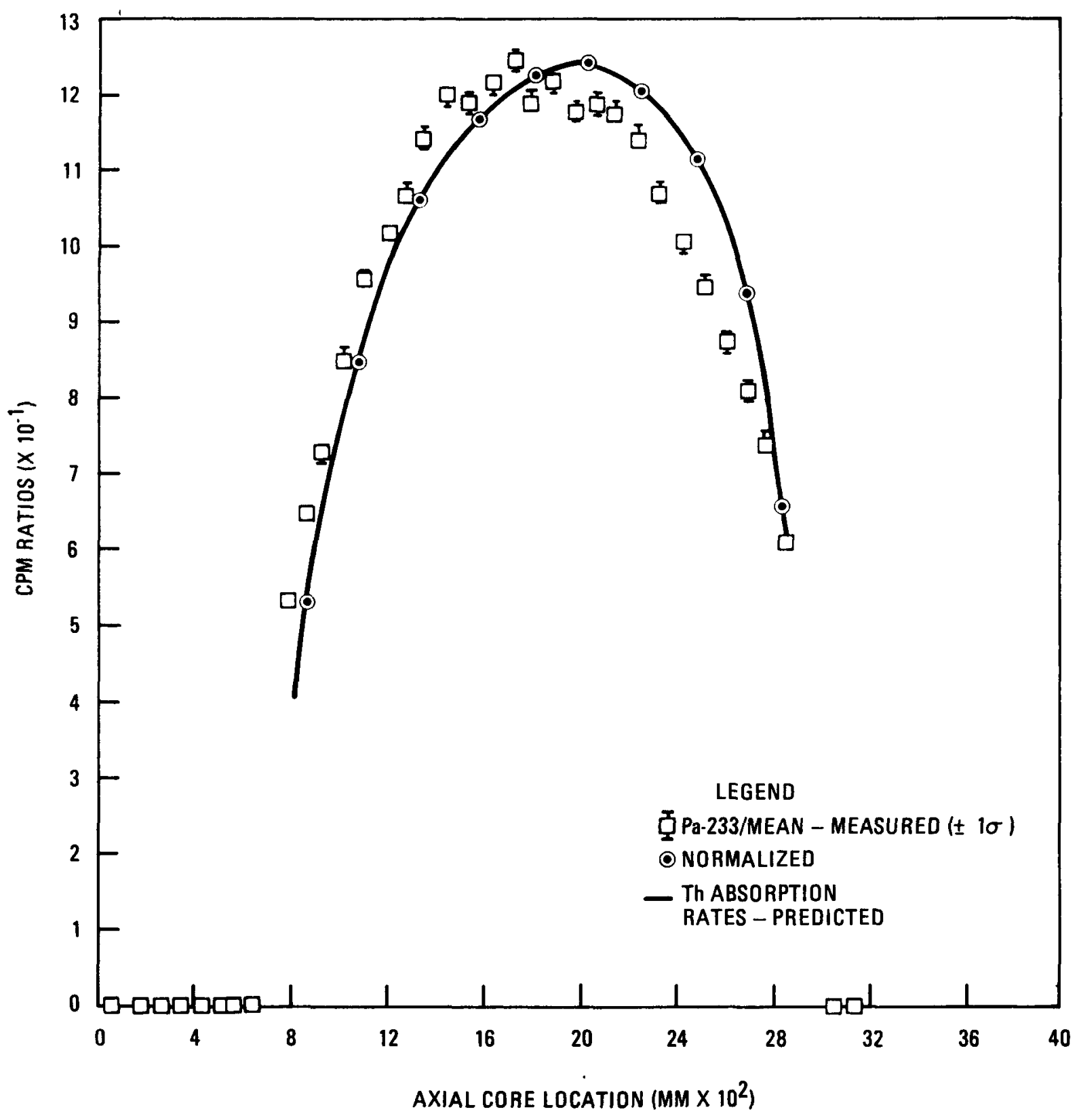

Fig. 3-4. Normalized protactinium CPM ratios for E14-01 
Measured radial core $\mathrm{Pa}-233$ profiles were found to be flatter than the calculated EOL thorium absorption rates.

6. Fuel stack dimensions of the driver fuel elements increased an average of $0.7 \%$, which was within the design limit of the elements. This stack expansion tended to increase with both higher temperatures and higher fast fluences.

Further details of the fuel gamma scanning and associated analyses performed are given in Ref. 4.

\subsection{PRIMARY CIRCUIT GAMMA SCANNING}

The plateout distribution and the total circuit inventory of gammaemitting radionuclides in the Peach Bottom primary cixcuit were determined by a two-phase program of gamma scanning. Phase I consisted of survey measurements of accessible ducting and of mapping the steam generator by axially traversing selected tubes from the water side with traveling detectors. Phase II, performed during component removal, completed the mapping of the primary circuit by gamma scanning portions of the ducting internally using traveling detectors inserted through openings in the ducting.

The purpose of the circuit gamma scanning was to measure the amount and distribution of plateout activity in order to: (1) test the validity of plateout models and predictions, (2) test the validity of total core release predictions (by integration of the plateout distribution), and (3) complement and complete on-going surveillance programs which monitored plateout levels throughout Core 2 operation. Specific objectives were:

1. To perform external gamma scans of loop 2 primary circuit ducting at 10 locations to complement previous loop 1 determinations by ORNL. 
2. To map the distribution of plateout activity in the loop 1 steam generator by traversing the length of approximately 80 tubes utilizing suitable ( $\mathrm{Cd} \mathrm{Te}$ ) detectors. This necessitated development of miniaturized detectors capable of gamma scanning within the tubes.

3. To perform a gross gamma scan of one helium circulator for indications of unusual plateout activity.

4. To determine specific activities of gamma emitters inside two vertical sections of ducting using specially designed gamma scanning apparatus.

5. To provide absolute plateout distributions by constructing laboratory mockups, performing suitable calibrations of on-site measurements, and reducing the data.

Gamma scanning was performed at various locations around loop 2 using a Ge(Li) detector and collimator as shown in Fig. 3-5. The loop 2 scanning locations, plus those checked in loop 1, are shown in Fig. 3-6.

Gamma scanning of the steam generator was performed from the water side, subsequent to removal of the channel head and baffles and blowing out the tubes. A miniaturized $\mathrm{Cd}$ Te detector was used as indicated in Fig. 3-7 to determine the axial plateout activity every $152 \mathrm{~mm}$ (6 in.) down the $6.1 \mathrm{~m}(20 \mathrm{ft})$ length of 79 tubes. Tubing locations scanned are shown in Fig. 3-8. The gamma spectra obtained in-situ during both ducting and steam generator scans were reduced to specific activities by calibration measurements on laboratory mockups using National Bureau of Standards (NBS) sources.

The Phase II internal scans were performed by lowering an intrinsic (non-1ithium-drifted) germanium detector through openings in the ducts at locations 4 and 10 in Fig. 3-6. The detector was kept central in the 


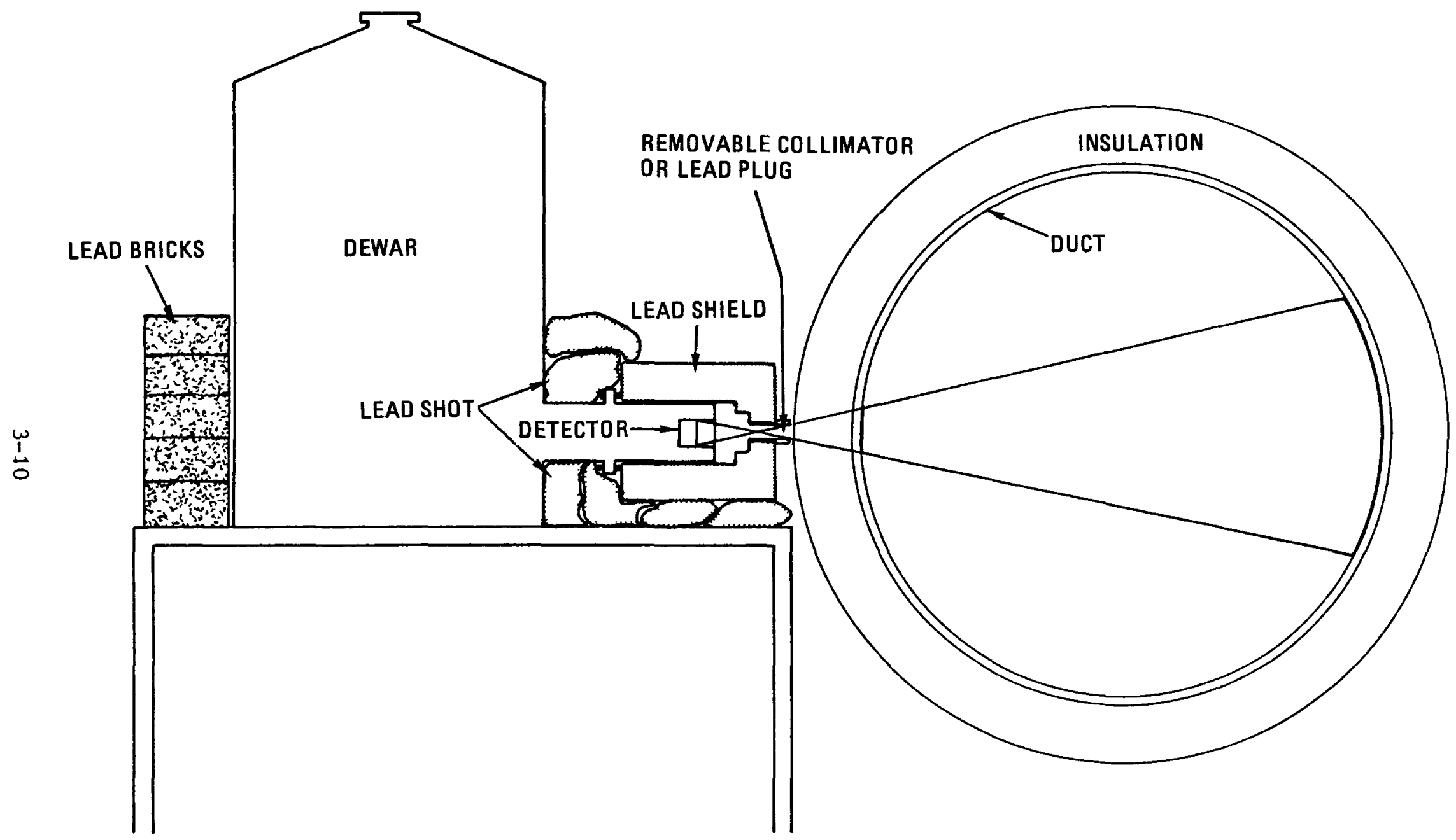

Fig. 3-5. Position of detector relative to standard helium duct 


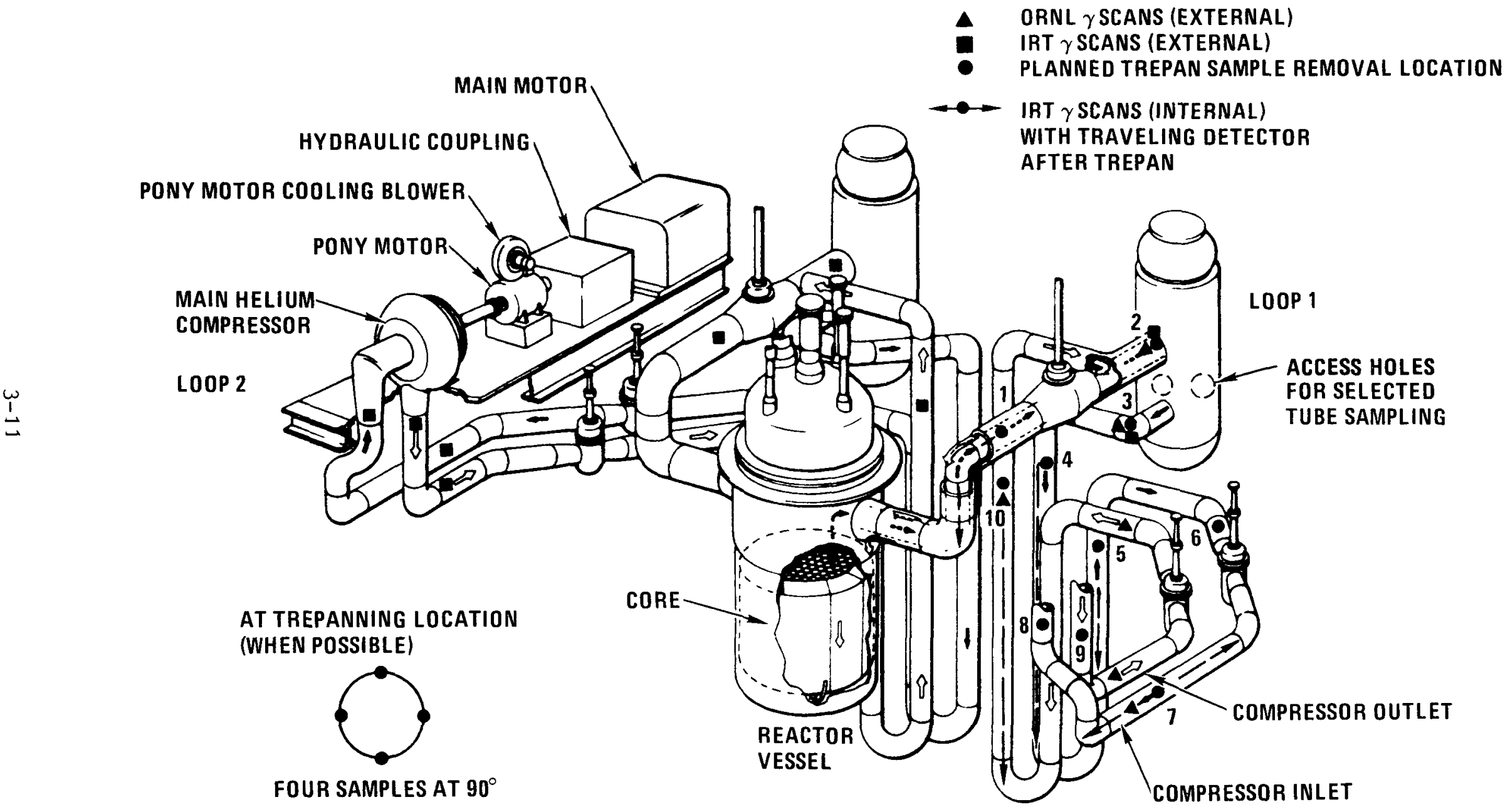

Fig. 3-6. Peach Bottom HTGR primary coolant system showing gamma scan and trepan sample removal locations 

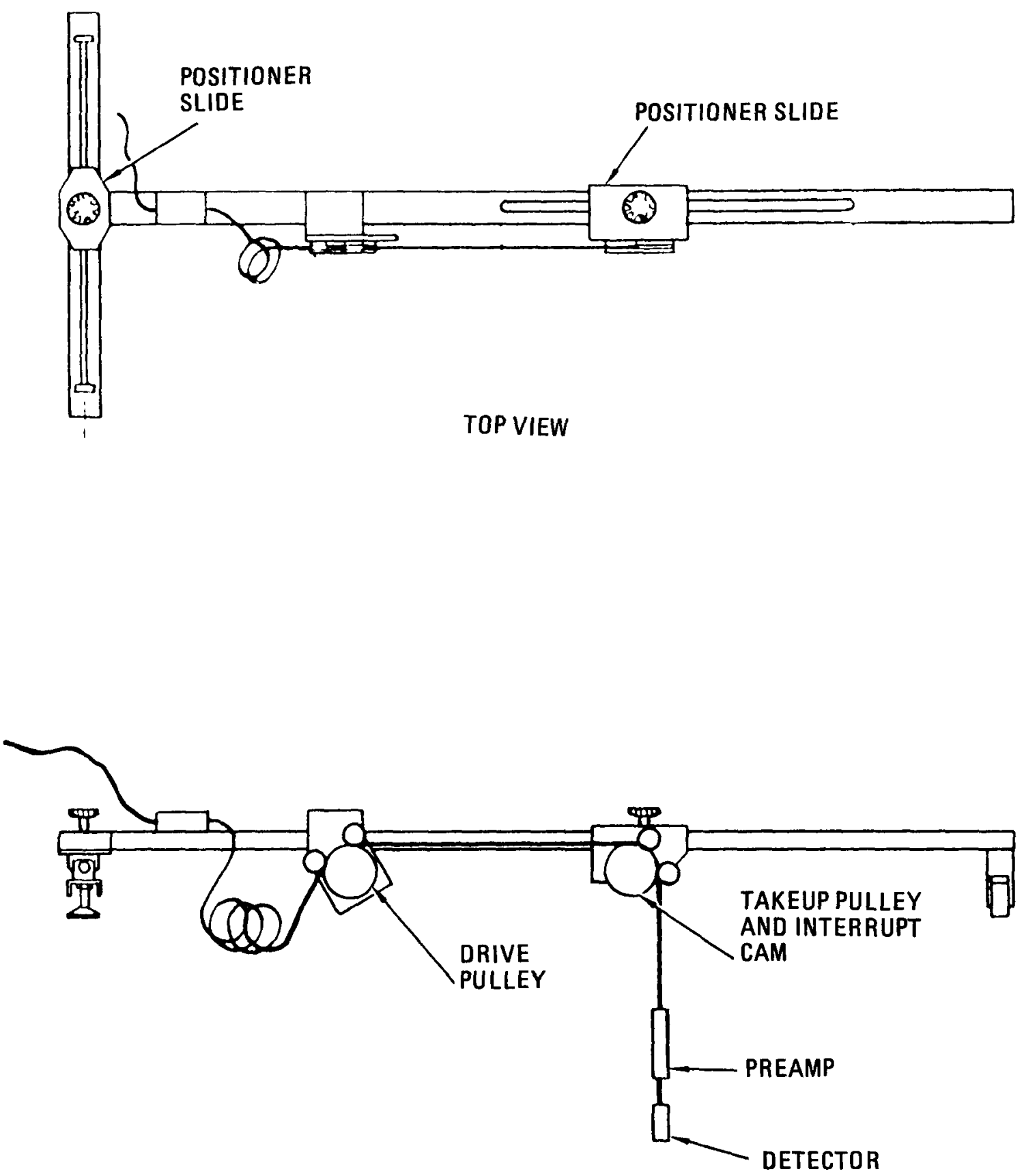

SIDE VIEW

Fig. 3-7. Cd Te detector positioning apparatus 


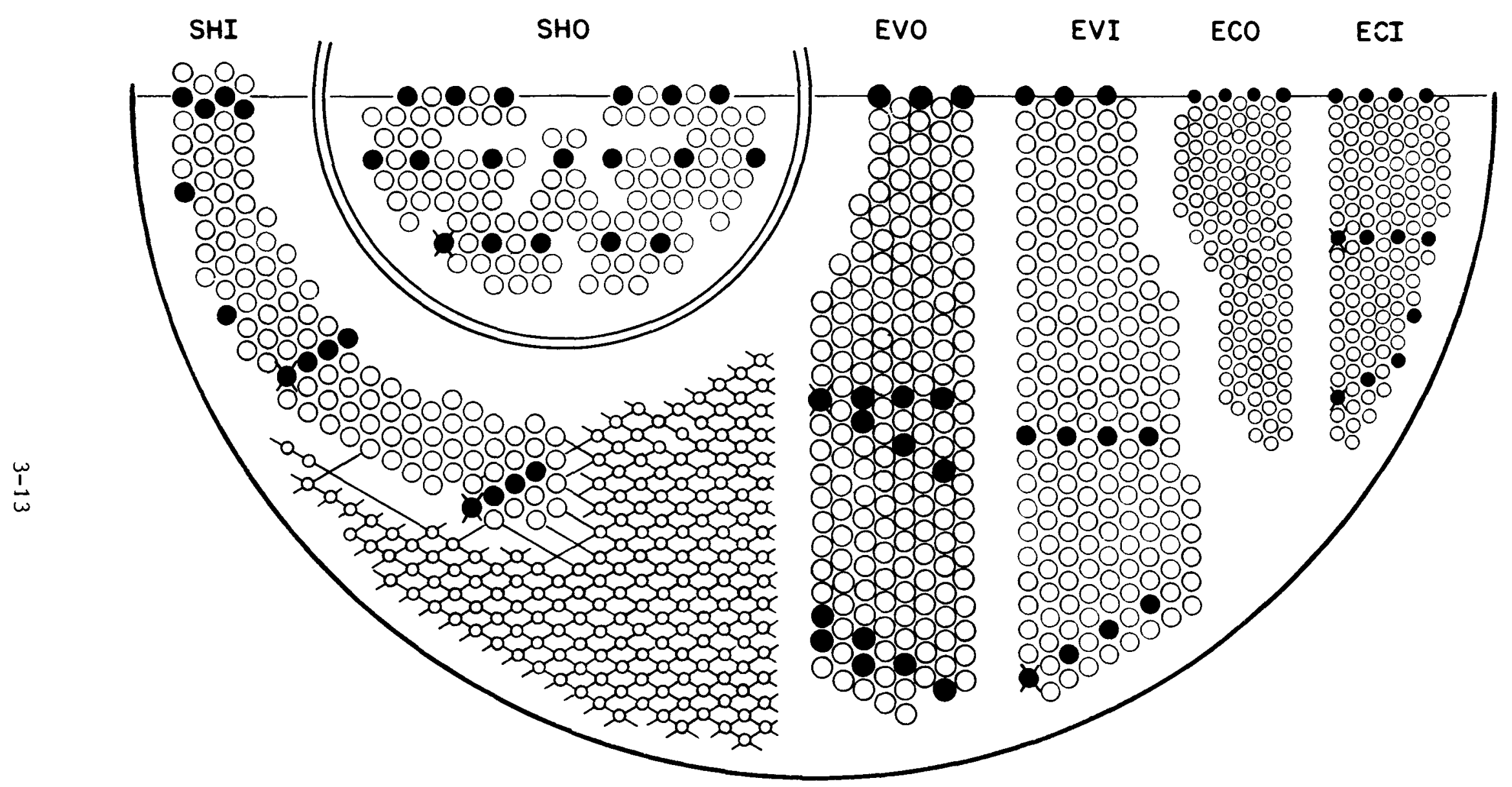

* also scan tube in other hemisphere

Fig. 3-8. Steam generator tube $\gamma$-scan locations 
ducts by a special locating mechanism, and counts were made every $152 \mathrm{~mm}$ (6 in.) throughout the traversed distance of approximately $6.1 \mathrm{~m}(20 \mathrm{ft})$. Again, the gamma spectra obtained in-situ were calibrated on a mockup at IRT.

The major conclusions from the circuit gamma scanning were as follows:

1. The only gamma emitting nuclides detected were Cs-134 and Cs -137 .

2. Cesium-134 plateout activities determined around the ducting varied from $3.1 \mathrm{Ci} / \mathrm{cm}^{2}$ at the steam generator outlet to approximately $1.0 \mathrm{Ci} / \mathrm{cm}^{2}$ at the concentric duct entrance to the reactor core. Cesium-137 values varied from 2.7 to $0.8 \mathrm{Ci} / \mathrm{cm}^{2}$ at the same locations.

3. A miniaturized $\mathrm{Cd}$ Te detector was developed and successfully used to provide detailed axial plateout distributions from the water side of 79 steam generator tubes. Its resolution was limited but proved adequate for this application.

4. Representative axial Cs-137 plateout distributions (Fig. 3-9) indicated an entrance effect in the region of the hot duct with the plateout distribution becoming more uniform as the coolant passed through the steam generator tube bundle.

5. Average specific activities (as illustrated for Cs-137 in the steam generator superheater section in Fig. 3-10) showed a significant gradient across the steam generator tube bundles.

6. Specific activities from internal duct scans indicated a decrease in activity in the direction of coolant flow (see Section 6.2).

7. A gross gamma scan of the loop 1 helium circulator indicated no unusual plateout activity or distribution. 


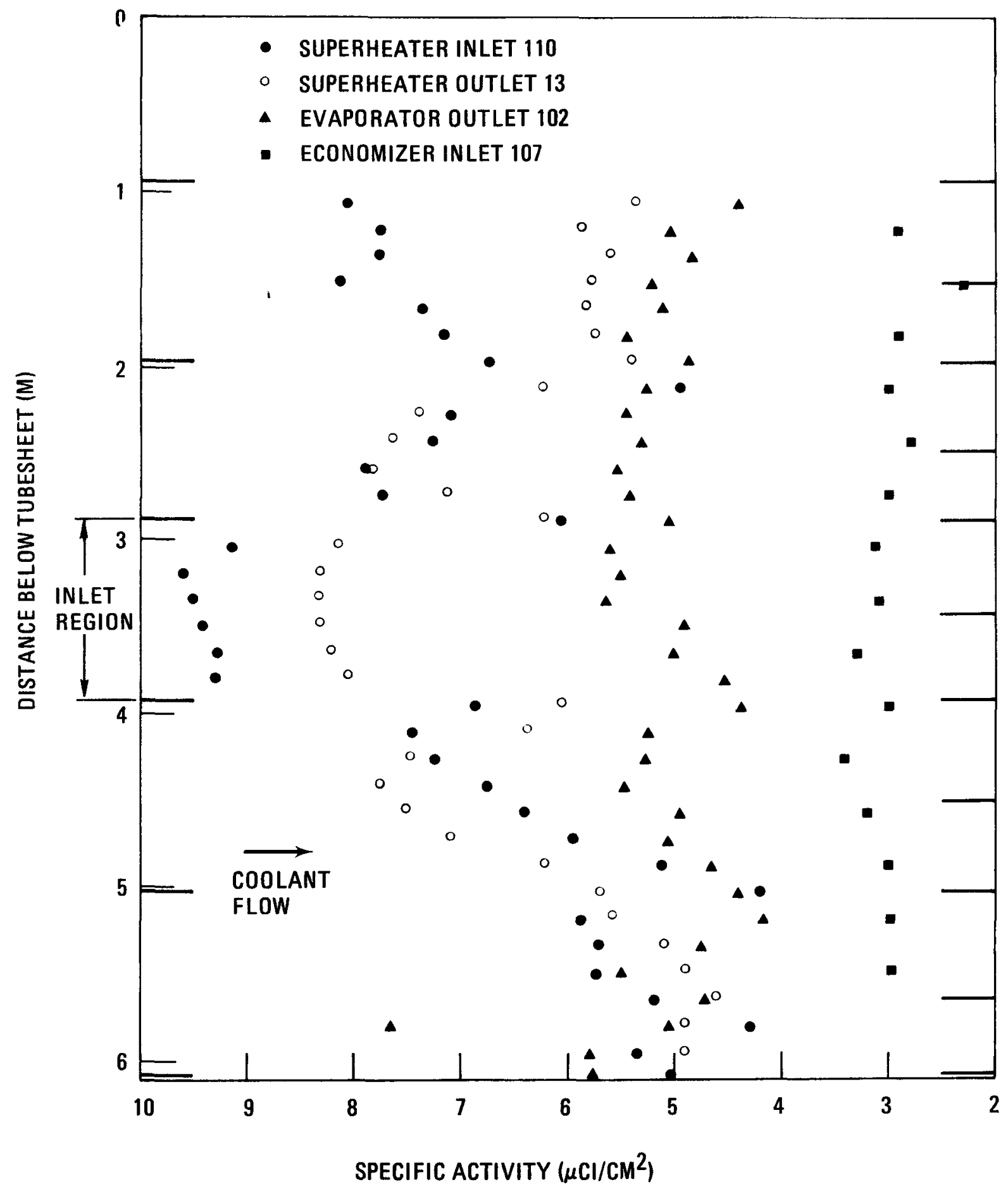

Fig. 3-9. Axial Cs-137 plateout distribution 


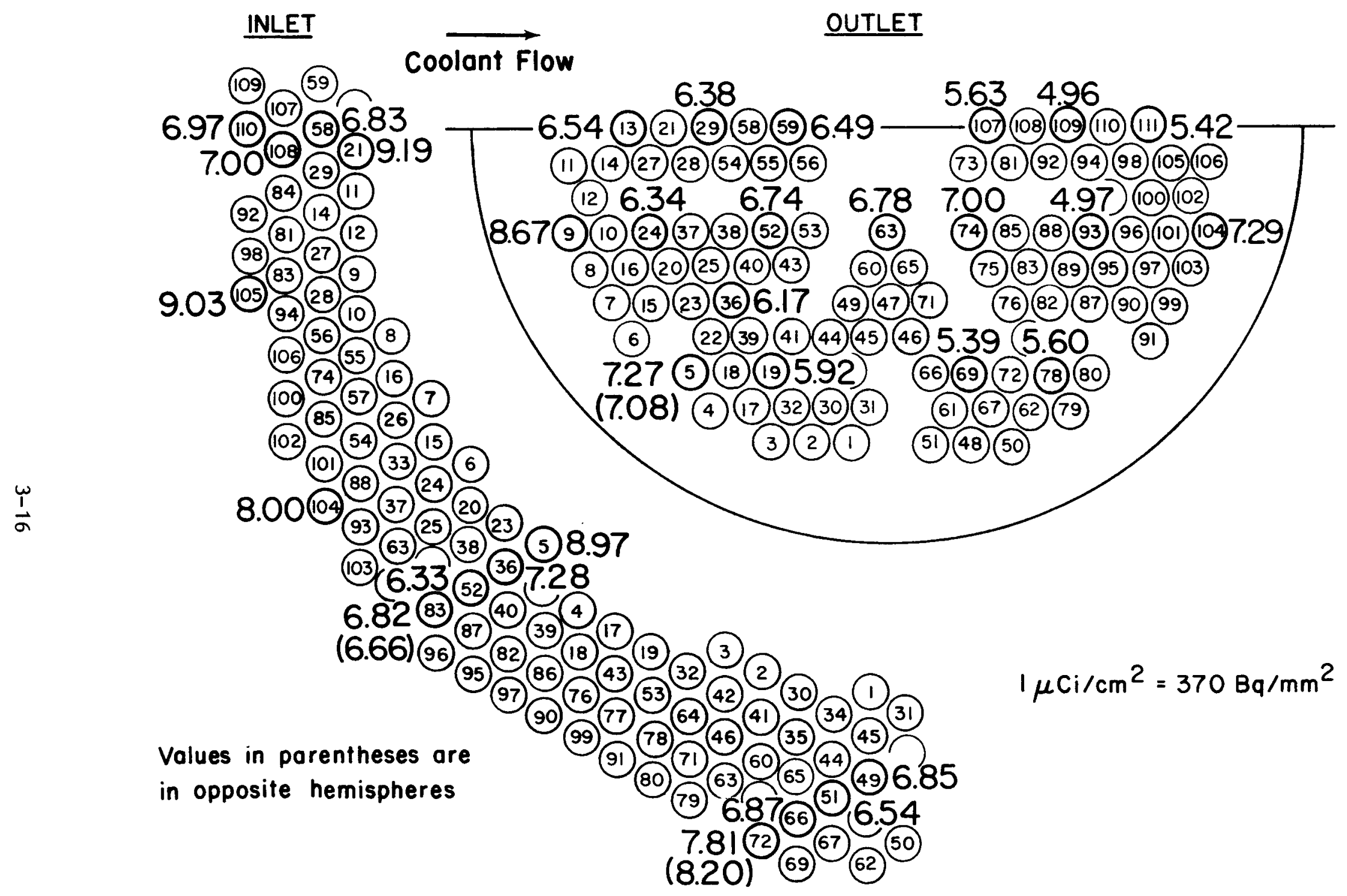

Fig. 3-10. Cs-137 plateout distribution in steam generator superheater, axial average specific activity $\left(\mu \mathrm{C} / \mathrm{cm}^{2}\right)$ 
Detailed comparisons of PAD code predictions with measured plateout values around the Peach Bottom circuit are given in Section 6.2 and Ref. 5 . Details of the circuit gamma scanning work and associated analyses performed appear in Ref. 6. 


\section{COMPONENT REMOVAL ACTIVITIES}

Selective removal of primary circuit components (samples) under the PBEOL Program was conducted on-site from October 1975 through February 1976. Catalytic, Inc., under subcontract to GA, performed the component remova1 activities utilizing local boilermaker labor with site support provided by Philadelphia Electric Company. The subcontract work scope included responsibility for planning, coordinating, and conducting the complete component removal program, including specialized tooling development in order to provide samples for subsequent radiochemical, metallurgical, and tritium permeation tests and analyses, and for absolute calibration of the in-situ gamma scans. Specific objectives were:

1. To remove four trepanned samples of primary circuit ducting at each of 10 locations around the circuit (including two hot duct locations).

2. To remove 26 superheater, 20 evaporator, and 20 economizer tube sections, 356 to $457 \mathrm{~mm}$ (14 to $18 \mathrm{in.)} \mathrm{long,} \mathrm{from} \mathrm{the} 100 \mathrm{p} 1$ steam generator.

3. To obtain six tube sections passing through a baffle plate.

4. To obtain two samples of the steam generator shroud - therma1 barrier assembly.

5. To provide access to the internals (both steam side and helium side) of the loop 1 steam generator for macroscopic examination by GA personnel. 
6. To provide access to the internals of the primary circuit ducting for internal gamma scanning by IRT Corporation and for limited macroscopic examination.

Trepan samples and locations were selected to provide absolute radiochemical calibration data to support previous primary circuit gamma scans (see Fig. 3-6). Steam generator tubing samples and locations (Fig. 4-1) were selected to represent all tubing bundles for subsequent laboratory analyses and also to support previous steam generator tubing gamma scans (Ref. 5). Location selection also considered proposed sampling techniques and access restrictions.

Component removal activities included planning and engineering, site preparation, mockup training and tooling development, duct trepanning operations, steam generator access, steam generator tube removal, and restoration and cleanup. The schedule of site activities is shown in Fig. 4-2, and details of the component removal activities are given in Refs. 7 and 8. General Atomic maintained a technical representative on-site throughout component removal. Highlights of the activities are presented below.

\subsection{COMPONENT REMOVAL HIGHLIGHTS}

Based on GA specifications, Catalytic Engineering initially developed specific methods for removal and packaging of the samples. This involved preparation of engineering specifications and control work packages; planning, scheduling and procurement; establishment of quality assurance, health physics and safety programs, and establishment of agreements with Philadelphia Electric Company, the Boilermakers Union, and General Atomic. Also included were the design and fabrication of special sample shipping containers; establishment of procedures for preserving sample identity, orientation, and traceability; and development of specialized tooling for component removal. 


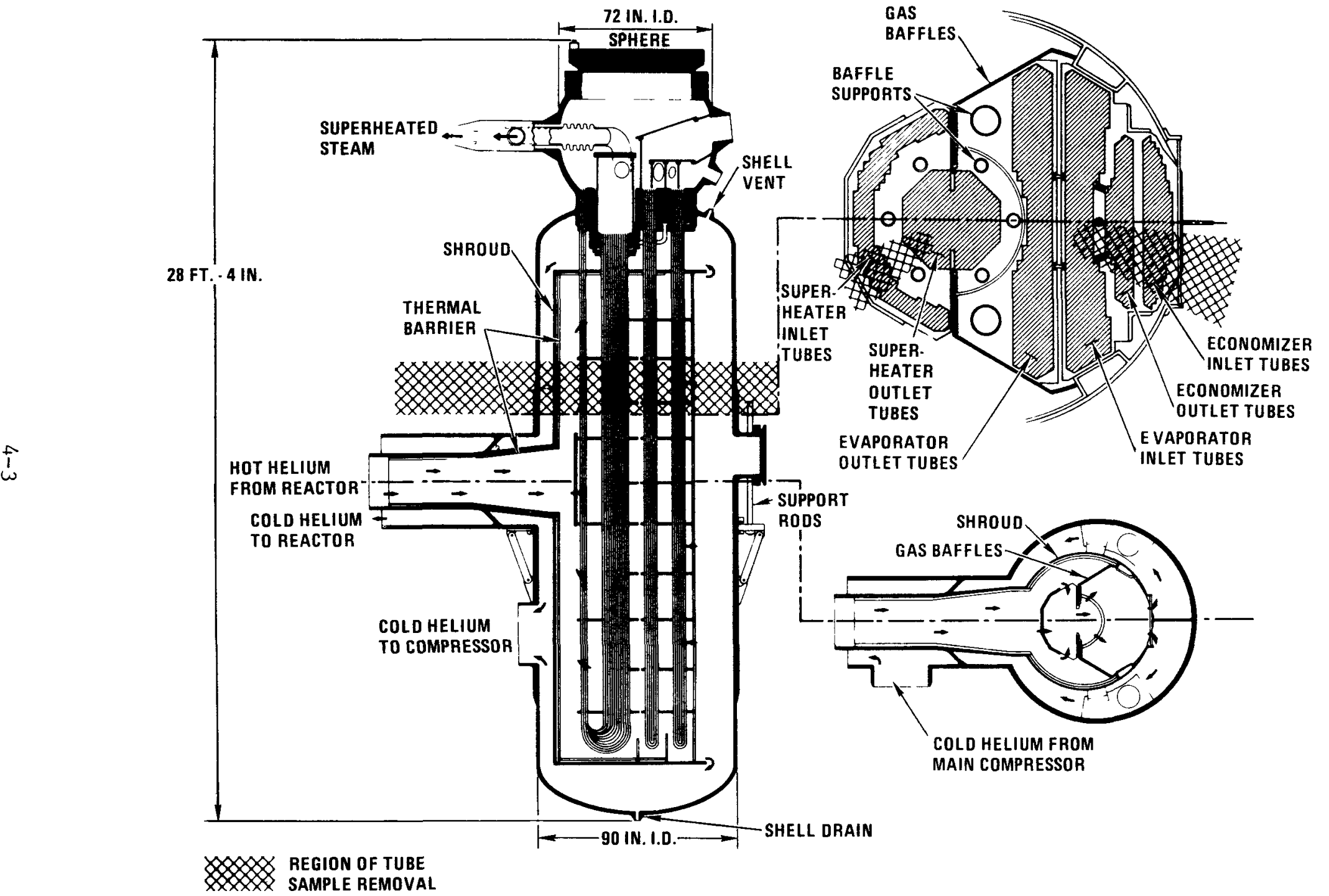

Fig. 4-1. Steam generator cross section showing regions of tube sample removal 


\begin{tabular}{|c|c|c|c|c|c|c|c|c|}
\hline \multirow{2}{*}{ KEY: } & \multirow{3}{*}{$\begin{array}{l}\text { ORIGINAL SCHEDULE } \\
\text { FINAL SCHEDULE }\end{array}$} & \multicolumn{4}{|c|}{1975} & \multicolumn{3}{|c|}{1976} \\
\hline & & OCTOBER & NOVEMBER & \multicolumn{2}{|c|}{ DECEMBER } & JANUARY & FEBRUARY & \multirow{2}{*}{\begin{tabular}{|c|} 
MARCH \\
7 \\
\end{tabular}} \\
\hline- & & $\begin{array}{ccc}7 & 14 & 21 \\
1 & 1 & 1 \\
\end{array}$ & $\begin{array}{rrr}7 & 14 & 21 \\
1 & 1 & 1 \\
\end{array}$ & $\begin{array}{lll}7 & 14 & 21 \\
1 & 1 & 1\end{array}$ & & $7 \quad 14 \quad 21$ & $\begin{array}{rrr}7 & 14 & 21 \\
1 & 1 & 1 \\
\end{array}$ & \\
\hline $\begin{array}{l}0 \\
\mathrm{~F}\end{array}$ & ERECTION OF CONTROL TENTS & & & & & & & \\
\hline $\begin{array}{l}\mathbf{0} \\
\mathrm{F} \\
\end{array}$ & ERECTION OF SCAFFOLDING & $=$ & & & & & & \\
\hline $\begin{array}{l}0 \\
F\end{array}$ & INSTALL ATMOSPHERIC CONTROL EQUIPMENT & & - & & & & & \\
\hline $\begin{array}{l}0 \\
\end{array}$ & INSTALL SHIELDING & & & & & & & \\
\hline $\begin{array}{l}0 \\
\mathrm{~F}\end{array}$ & REMOVE EXTERIOR INSULATION & & $\cdots$ & & & & & \\
\hline $\begin{array}{l} \\
\end{array}$ & TREPAN SAMPLE DUCTING & & $=$ & $=$ & 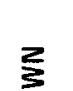 & & & \\
\hline $\begin{array}{l}0 \\
\mathrm{~F}\end{array}$ & PATCH WELD TREPAN OPENINGS & & & -- & 总 & & & \\
\hline $\begin{array}{l}\mathbf{0} \\
\mathrm{F}\end{array}$ & CUT STEAM GENERATOR SHELL & & $=$ & & 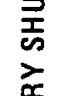 & & & \\
\hline $\begin{array}{l}0 \\
\mathrm{~F}\end{array}$ & CUT STEAM GENERATOR SHROUD & & & & $\begin{array}{l}\frac{\alpha}{\alpha} \\
\frac{\alpha}{\alpha}\end{array}$ & $=$ & & \\
\hline $\begin{array}{l}\mathbf{0} \\
\mathrm{F} \\
\end{array}$ & CUT STEAM GENERATOR TUBES & & & - & 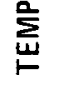 & & & \\
\hline $\begin{array}{l}\mathbf{0} \\
\mathrm{F} \\
\end{array}$ & $\begin{array}{l}\text { PATCH WELD STEAM GENERATOR HOLES } \\
\end{array}$ & & & $-\cdots$ & & & 二 & \\
\hline $\begin{array}{l}\mathbf{0} \\
\mathrm{F}\end{array}$ & CLEAN-UP (CAVITY) & & & $---\alpha$ & & & & \\
\hline $\begin{array}{l}0 \\
\mathrm{~F}\end{array}$ & CLEAN-UP (REFUEL FLOOR) & & & - & & & & \\
\hline $\begin{array}{l}\mathrm{O} \\
\mathrm{F} \\
\end{array}$ & PACKAGE COMPONENT SAMPLES & & & +- & & & & \\
\hline $\begin{array}{l}\mathbf{0} \\
\mathbf{F} \\
\end{array}$ & $\begin{array}{l}\text { PERSONNEL TRAINING (HEALTH PHYSICS, } \\
\text { MOCK-UP, AND SAFETY) }\end{array}$ & --⿱亠乂 & & - & & - & & \\
\hline
\end{tabular}

Fig. 4-2. End-of-life component removal schedules, original versus final 
The site preparation phase of the project included all work necessary prior to initiating actual component removal. This involved setup of the site office; health physics, safety, and mockup training of craftsmen; removal of the steam generator channel head; erection of scaffolding and controlled access tents; installation of electrical power supplies, atmosphere control systems, and shielding; and removal of ducting and steam generator insulation.

Only one control tent was erected around the steam generator due to space limitations. A second control tent was erected in the cavity around the concentric ducting and hot valve (locations 1 and 2 in Fig. 3-6) to control possible airborne activity upon removal of the outer duct. Both tents had conditioned atmospheric control as well as humidity control in order to maintain tolerable working conditions and humidity less than $30 \%$ as specified by GA. A cavity entrance control tent was also erected on the refueling floor, and a controlled area was established nearby for packaging and testing component samples.

Erection of mockups of the steam generator tube bundle and primary coolant ducting began immediately upon the initiation of site work. A control tent was built around the steam generator mockup to create rea1istic working conditions. When performing mockup training, craftsmen wore protective clothing and breathing apparatus to duplicate that required in the actual work area (Fig. 4-3). Mockup training ensured complete familiarity with machines and procedures and thereby minimized subsequent errors and personnel exposure. Mockup work was also valuable in development and modification of tooling, thereby minimizing lost manhours and total manrem exposures for the program.

The trepan cutting tool used on the ducting could be mounted with chains directly to the pipe where the trepan sample was to be taken (Fig. 4-4). The cutting mechanism consisted of a pilot drill bit and a hole saw attached to a modified drill press. The entire operation could be controlled remotely at distances up to $9.1 \mathrm{~m}$ (30 ft). 


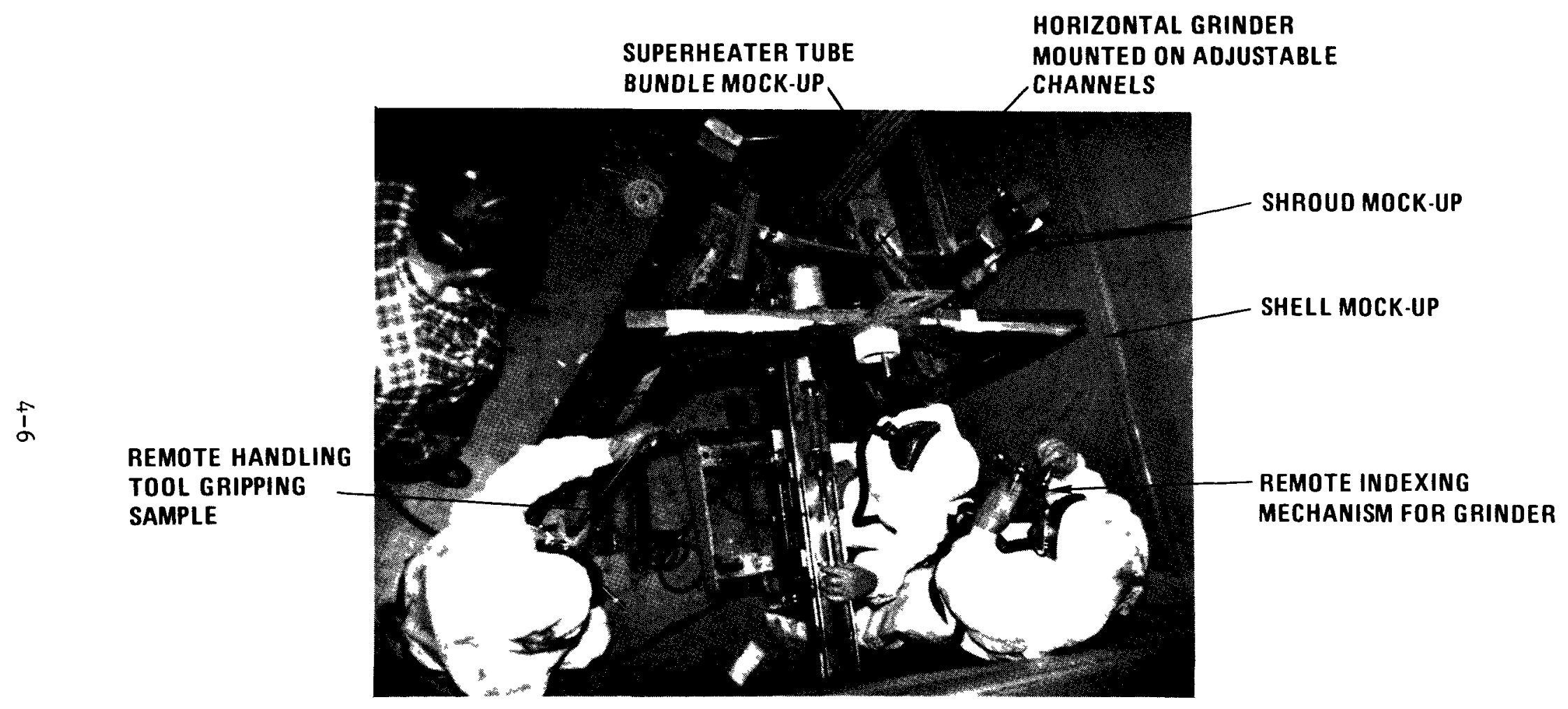

Fig. 4-3. Steam generator tube bundle mockup showing practice tube removal in progress 


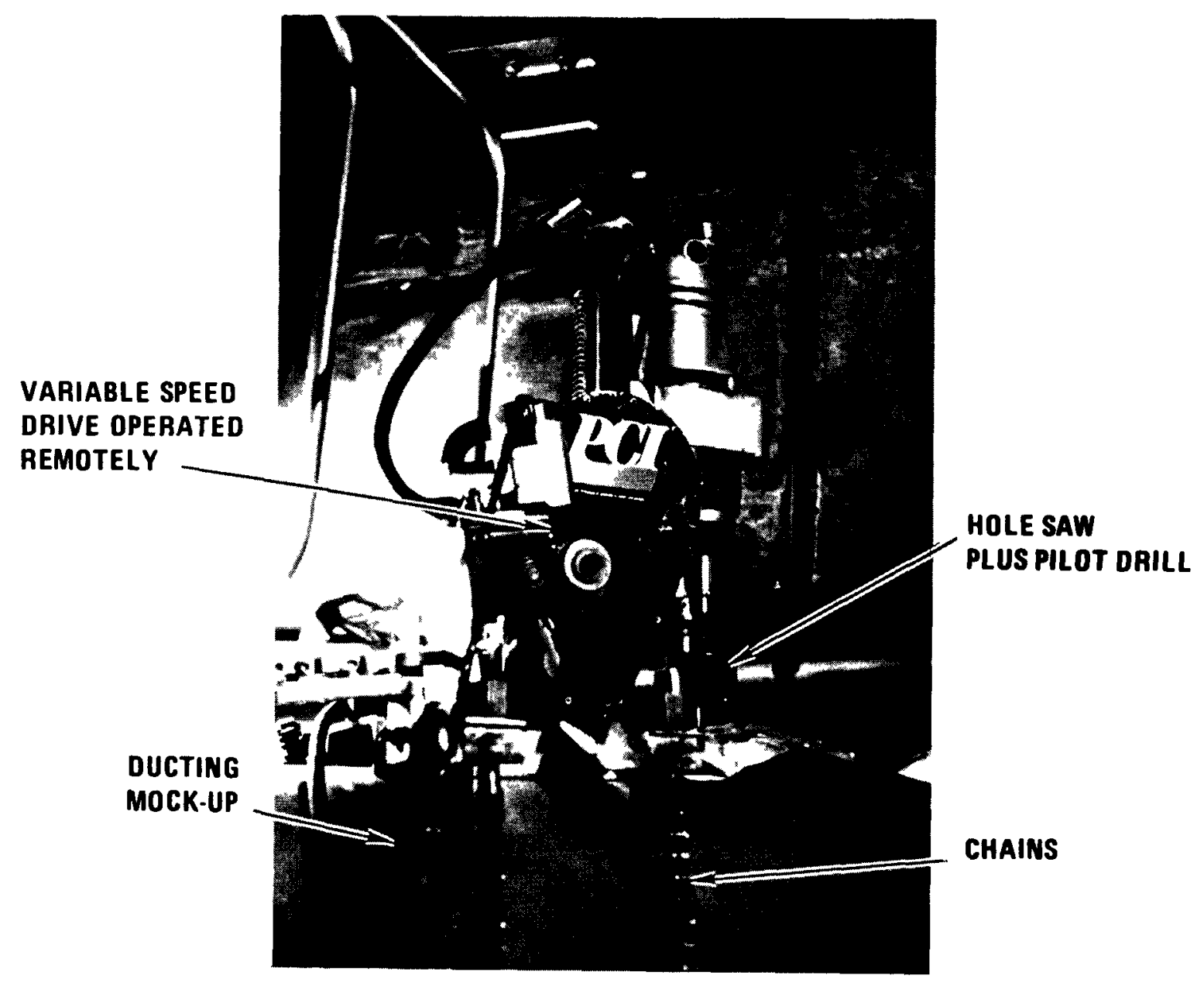

Fig. 4-4. Trepan cutting tool mounted on ducting mockup 
The external steam generator tubing cutter, which consisted of two side grinders that were driven through the tubes by a remotely controlled sliding channel, attached to a base that mounted to the superheater she11. External tube cutting was a three-man operation, one craftsman controlling the grinder switch, one craftsman grasping the tube being cut with a remote handling tool, and a third craftsman controlling the drive channel (see Fig. 4-3).

The trepanning operations were successfully completed on December 17, 1975. Subsequent to completion of trepanning, locations 4 and 10 (see Fig. 3-6) were further enlarged to provide access for internal gamma scanning of the ducts, as discussed in detail in Ref. 5.

Access to the steam generator was attained by a combination of arc gouging and grinding. After removing the access opening of the superheater shell, the shroud was exposed and a strip of the shroud and thermal barrier insulation was removed for subsequent examination. The activity levels measured in the steam generator tent which strongly affected subsequent tube removal operations are shown in Fig. 4-5.

Removal of Incoloy 800 superheater tubes proceeded as planned with the external grinding apparatus. All tube samples were identified and marked for in-place location and orientation. Each tube in a specific section was assigned a unique number and marked and labeled upon removal. A Quality Assurance representative was present at all times during tube removal to ensure proper identification and marking of the tubes.

Superheater tube cutting operations using the external grinding apparatus in Fig. 4-3 went extremely well, attesting to the value of the previously detailed mockup training. A total of 48 tubes and 3 tube stubs [102 mm (4 in.) length including the tube/baffle plate interaction regions] were cut from the superheater section over a period of 5 days. Supervisory personnel monitored the work in a nonradioactive environment through the use of a closed-circuit television and loudspeaker system. 


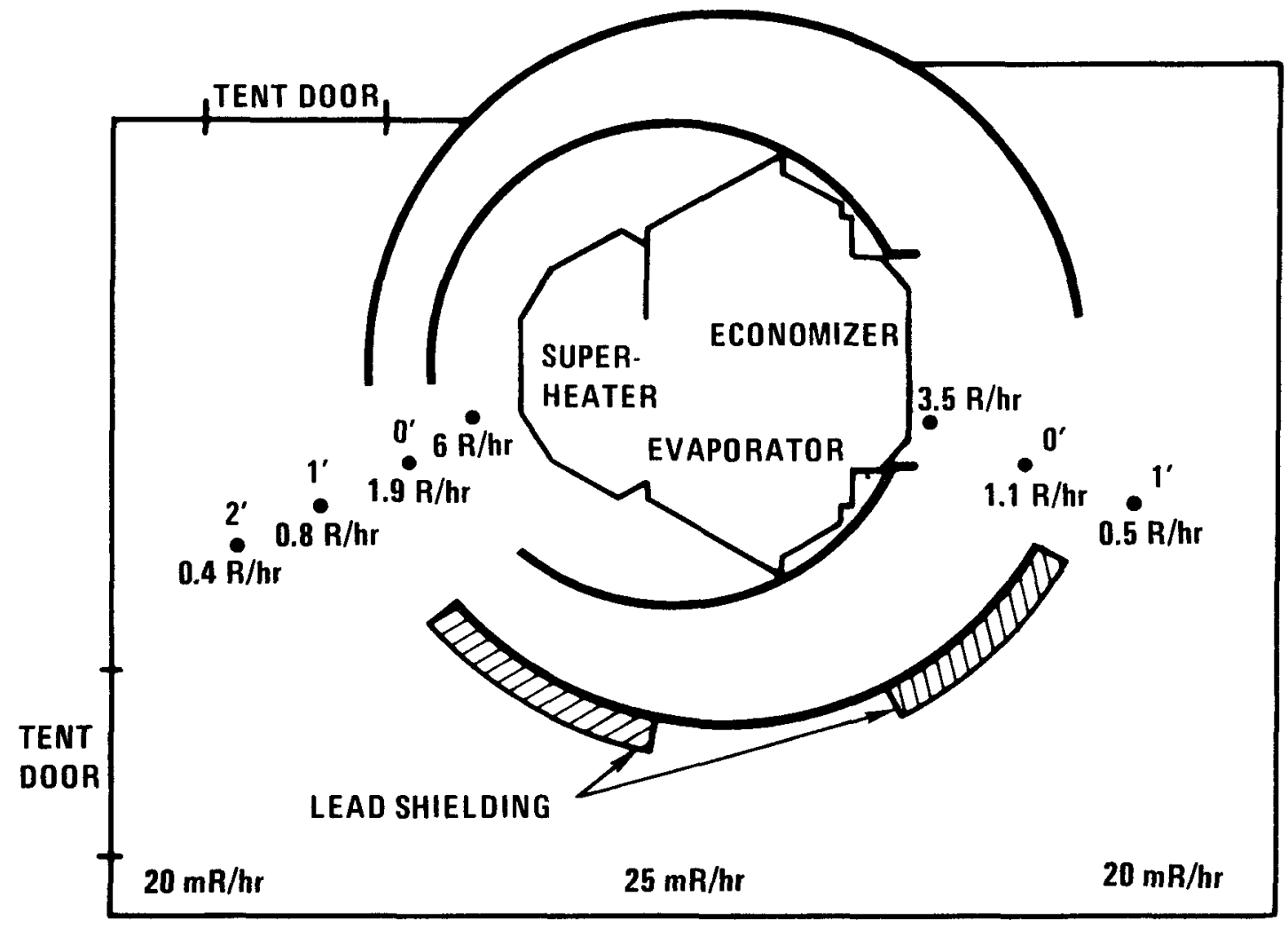

Fig. 4-5. Radiation levels at various locations in the steam generator tent 
External cutting of the economizer tubes also proceeded smoothly. Over 150 tubes were cut in this section to facilitate a tube removal path to the evaporator section (see Fig. 4-1). The evaporator tubes were cut using special internal cutting tools operated from the top of the steam generator, and samples were removed through the access window. Table 4-1 lists all the samples removed and shipped to GA.

After sampling work was completed, the steam generator cavity was decontaminated to levels below the limits required for a decommissioned facility. All openings which had been made in the primary system were seal-welded. The control tents were decontaminated, dismantled, and disposed of as radioactive waste.

In summary, although some difficulties were encountered, component removal was completed successfully, without any significant health physics or safety incidents, and provided the required primary circuit access locations and samples needed for subsequent detailed examinations by GA. 
TABLE 4-1

PEACH BOTTOM HTGR PRIMARY COOLANT SYSTEM SAMPLES SHIPPED TO GENERAL ATOMIC

\begin{tabular}{lr} 
Trepan samples (cold duct) & 27 \\
Trepan samples (concentric duct - outer pipe) & 3 \\
Trepan samples (concentric duct - inner pipe) & 5 \\
Trepan samples (concentric duct SolAMI (a) & 5 \\
Superheater tube samples & 48 \\
Economizer tube samples & 36 \\
Evaporator tube samples & 18 \\
Superheater tube sections through baffle plate & 3 \\
Superheater shroud sample & 1 \\
Economizer shroud tie rod & 1 \\
Superheater steam outlet pipe & 1 \\
\hline
\end{tabular}

(a) Thermal barrier material. 


\section{LABORATORY EXAMINATIONS}

The laboratory examinations of removed components at GA included radiochemical, metallurgical, and tritium permeation tests. Tubing samples were also sent to Harwell, England, for cesium desorption measurements and to the Commissariat a L'Energie Atomique (CEA), France, for fission product blowdown tests. These latter tests are being funded and reported separately.

\subsection{RADIOCHEMICAL EXAMINATIONS}

Radiochemical examinations were performed on all samples removed from the primary circuit and the steam generator to provide absolute calibration of the on-site gamma scan measurements and to provide basic data for fission product design verifications. Specific objectives were:

1. To perform gamma counting of samples and provide backup fission product distribution data for substantiating in-situ gamma scans.

2. To conduct leaching experiments to determine $\mathrm{Sr}-90, \mathrm{Cs}-137$, and I-131 specific activity levels and to evaluate the effectiveness of candidate decontaminating agents.

3. To examine and characterize carbonaceous deposits on the samples.

4. To determine cesium diffusivity and sorptivity in Peach Bottom fuel element materials and compare with large HTGR reference values.

5. To perform fission gas release tests on irradiated and archive fuel components to provide baseline data for fission gas release design verifications. 
The steam generator tubing and ducting trepan samples were first gamma scanned incrementally using the apparatus shown diagrammatically in Fig. 5-1. Details of the apparatus and technique used, together with details of the tests summarized below, are given in Ref. 9 .

After macrophotography and sectioning, samples from various locations were acid leached to remove all surface activity and the leach solutions were analyzed for gamma and beta activity. This provided specific surface activities for all resolvable radionuclides, thus providing absolute calibration of the gamma scanning data and additional mapping of the plateout distribution in the primary circuit. The leach solutions were also submitted for TRIGA neutron activation analysis to determine the levels of iodine plateout.

Selected tube specimens were subjected to microprobe examination to determine the chemical form and possible extent of metallic fission product penetration into the base material. Decontamination studies were directed toward the development and testing of reagents and processes by which deposited fission products could be removed from primary loop components.

Fission gas release measurements were made on archive and irradiated Peach Bottom fuel compacts to provide beginning-of-life and end-of-1ife noble gas release values. The determinations of $\mathrm{Kr}-85 \mathrm{~m} \mathrm{R} / \mathrm{B}$ at $1373 \mathrm{~K}$ were made using an existing TRIGA reactor King furnace facility. The $\mathrm{R} / \mathrm{B}$ data determined were then employed to refine fission gas release predictions and to check calculated particle failure fractions.

Relative cesium sorption determinations were made on archive Peach Bottom sleeve graphite, spine graphite, and matrix material as functions of concentration and temperature. In addition, the diffusivities of $\mathrm{Cs}$ in Peach Bottom fuel element sleeve and spine graphite archive materials were determined at two temperatures. The Cs sorptivities and diffusivities so determined were subsequently employed to refine fuel element and total core metallic release predictions. 


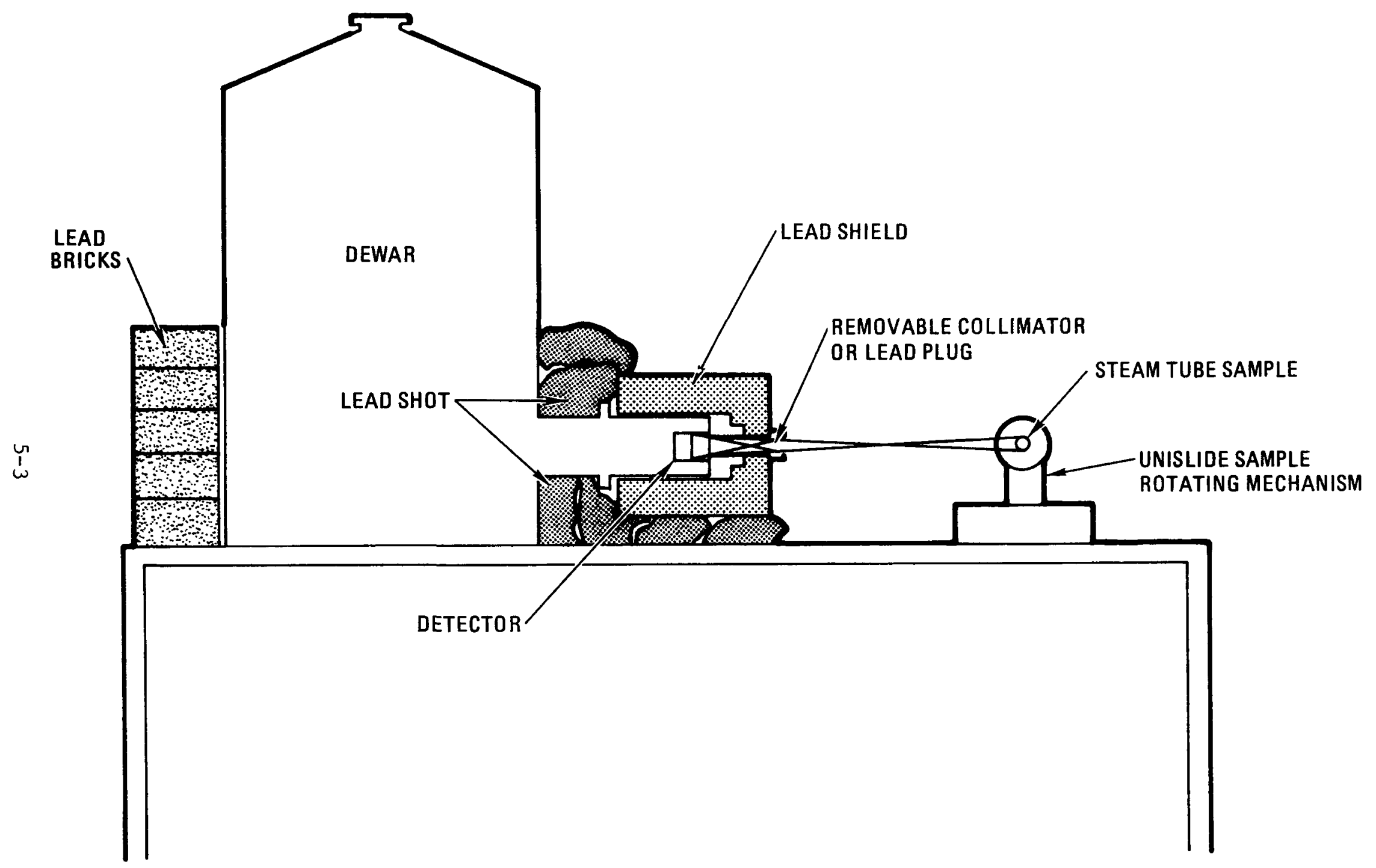

Fig. 5-1. Diagram of equipment and geometry for gamma scanning of tube samples 
The major results and conclusions from the radiochemical studies can be summarized as follows:

1. Specific activities in the primary circuit ranged from $\sim 17$ to $\sim 1 \mu \mathrm{Ci} / \mathrm{cm}^{2}$ for $\mathrm{Cs}-134$ and from $\sim 8$ to $\sim 1 \mu \mathrm{Ci} / \mathrm{cm}^{2}$ for $\mathrm{Cs}-137$. A decrease in Cs activity in the direction of coolant flow was indicated as anticipated (Fig. 5-2), together with an increase in the Cs-137/Cs-134 ratio.

2. Very good agreement was found between specific activities determined radiochemically on ducting samples and those determined during in-situ gamma scanning. The two cesium isotopes were the only gamma emitters detected in significant amounts. Occasionally, trace amounts of Co-60 were detected.

3. Sr-90 specific activity levels obtained from leach solution radiochemistry were in the range of $5 \times 10^{-4}$ to $8 \times 10^{-3} \mu \mathrm{Ci} / \mathrm{cm}^{2}$, several orders of magnitude lower than cesium activities. Activation of leach samples indicated no detectable I-129 $\left(\leq 2 \times 10^{-5}\right.$ $\mathrm{Ci} / \mathrm{cm}^{2}$ ), indicating that the fuel element purge system was effective in controlling iodine release.

4. The carbonaceous deposits on superheater tube samples contained $80 \%$ to $100 \%$ carbon, $2 \%$ to $3 \%$ iron, and traces of chromium and sulfur. Gamma analysis of the flakes showed that approximately $80 \%$ of the total gamma (cesium) activity was associated with the deposit.

5. Compared with H-327 graphite, Peach Bottom fuel element spine graphite was slightly less sorptive and sleeve graphite slightly more sorptive of $\mathrm{Cs}$. Peach Bottom compact matrix material was about 12 times more sorptive than bulk H-327 graphite and about 6 times more sorptive than bulk Peach Bottom sleeve graphite. 


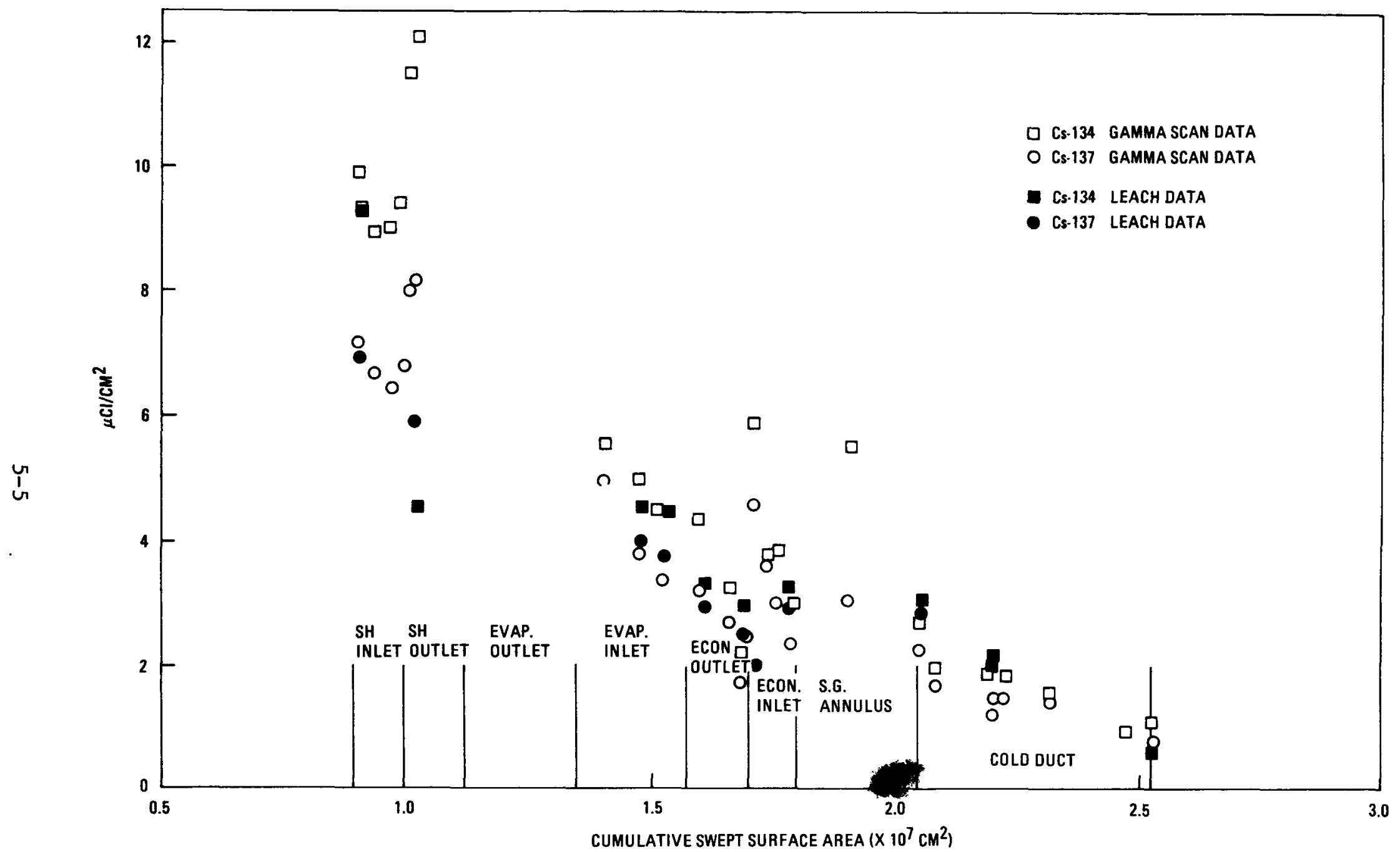

Fig. 5-2. Cesium plateout distribution in Peach Bottom primary circuit derived from gamma scanning and leach data 
6. Peach Bottom fuel element spine graphite was 3 to 4 times more permeable to cesium than H-451 graphite, whereas the sleeve graphite was 10 to 20 times less permeable.

7. An average $\mathrm{Kr}-85 \mathrm{~m} \mathrm{R} / \mathrm{B}$ value of $2.6 \times 10^{-4}$ was established for two archive compacts. The $\mathrm{R} / \mathrm{B}$ data for the irradiated fuel compacts were higher than would have been expected on the basis of the fraction of failed particles (see Table 5-1). The higherthan-expected $R / B$ values were found to be due to fuel hydrolysis that occurred after the fuel was removed from the reactor. This was demonstrated by metallurgical sectioning through the compacts (Fig. 5-3).

TABLE 5-1

DETERMINATION OF FAILED PARTICLE FRACTIONS IN PEACH BOTTOM FUEL COMPACTS

\begin{tabular}{c|c|c}
\hline $\begin{array}{c}\text { Element } \\
\text { No. }\end{array}$ & Compact & $\begin{array}{c}\text { Particle } \\
\text { Failure } \\
(\%)\end{array}$ \\
\hline E01-01 & 14 & $\sim 1.5(\mathrm{a})$ \\
F03-01 & 3 & $5.5(\mathrm{a})$ \\
F03-01 & 12 & $3.3(\mathrm{~b})$ \\
Average & & 3.4 \\
\hline
\end{tabular}

(a) Determined at ORNL by hot chlorine leach.

(b) Determined at GA by metallographic examination.

\subsection{METALLURGICAL EXAMINATIONS}

The metallurgical examinations were performed to evaluate the condition of steam generator, ducting, and thermal barrier materials after approximately 7 years of reactor operation and to determine the suitability of these materials in reactor service. Specific objectives were: 

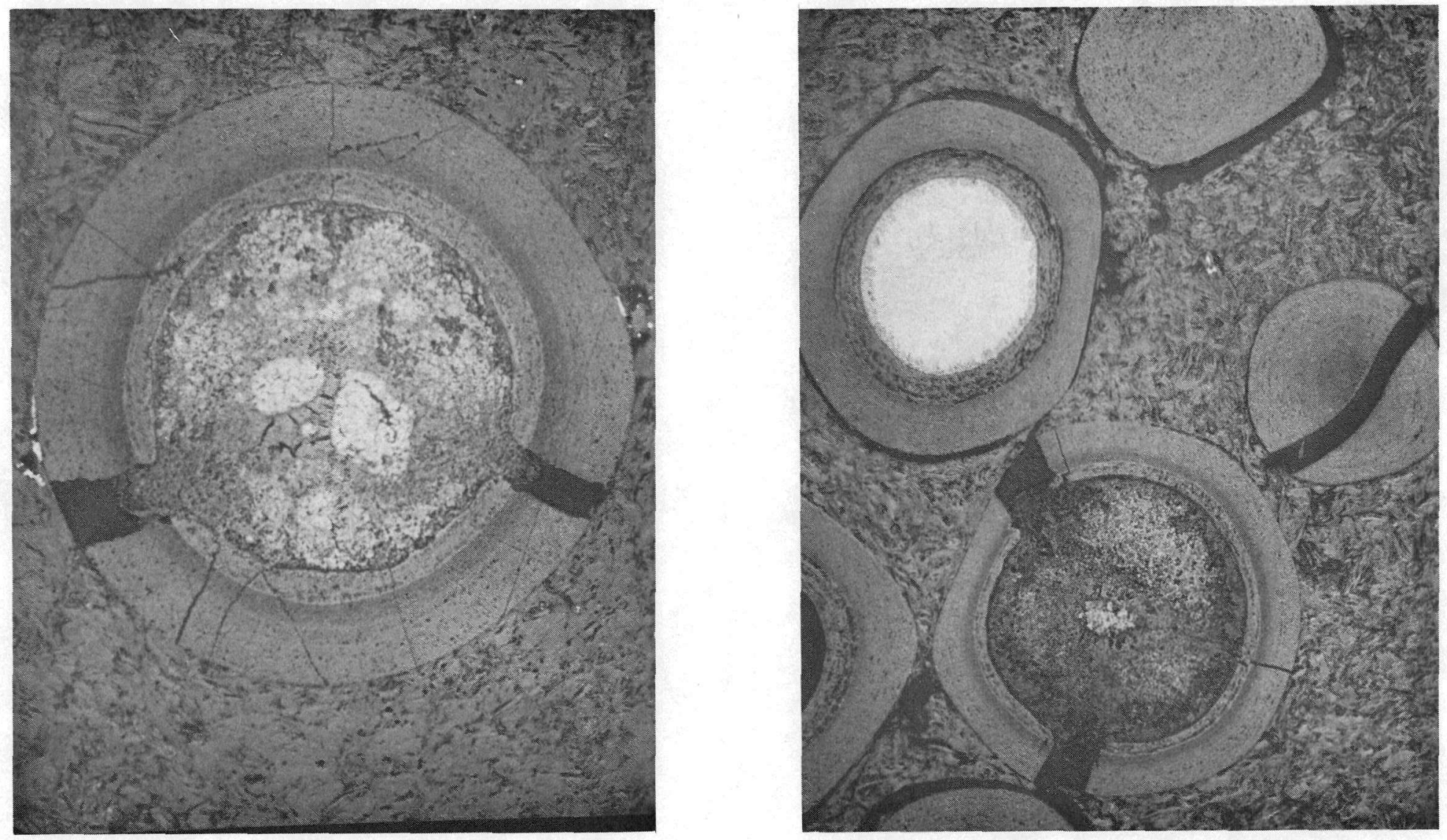

Fig. 5-3. Photomicrographs of compact 12 from F03-01 showing the extent of hydrolysis of failed fuel particles 
1. To examine steam generator and ducting internal surfaces in-situ.

2. To determine the extent and nature of primary coolant and/or secondary coolant interactions with metals.

3. To evaluate significant microstructural changes due to aging.

4. To determine residual mechanical properties of reactor samples and compare with those of archive or similar materials.

5. To evaluate friction and wear damage on rubbing surfaces.

\subsubsection{Macroscopic Examinations In-Situ}

During the component removal phase, access was provided to the ducting and to both the helium and steam sides of the steam generator internals. Macroscopic examinations were performed (1) by inserting borescopes inside the steam generator tubes from the tubesheet and (2) by inspecting the ducting and steam generator internals through the sampling access locations both visually and using a chamberscope developed specially for this purpose. The major results from the steam generator macroscopic examinations were as follows:

1. Borescopic examinations showed no evidence of corrosion, stress corrosion cracking, or pitting on the secondary (water) side of the steam generator tubing. The general appearance of the tube surfaces indicated the presence of thin oxide films and, in general, the tubes were in excellent condition. Examination of the tubesheet surface and tube-to-tubesheet welds revealed no evidence of unusual corrosion, erosion, or cracking. However, some minor erosion/corrosion damage was present in the carbon steel economizer/evaporator inlet ferrules.

2. The helium-exposed surfaces of the ducting and the steam generator were uniformly covered with a thin matt-black coating. 
The steam generator superheater outlet tubes were covered by a comparatively thick black deposit (Fig. 5-4). Detailed examination showed that the scale was multilayered (Fig. 5-5), with up to five distinct layers being visible on some tubes. This deposit probably resulted from the oil ingress into the primary circuit which occurred periodically during reactor operation.

3. Friction and wear damage was generally minor. However, some surface abrasion and fretting were observed in the regions where the steam generator tubes pass through the support plates (Fig 5-6). It was subsequently shown, however, that the depth of fretting damage was $\leq 0.025 \mathrm{~mm}$ ( $\leq 0.001$ in.), well within design margins.

4. The 3-mil stainless steel thermal barrier foils showed excellent ductility (Fig. 5-4), indicating no significant degradation during reactor service.

\subsubsection{Laboratory Examinations of Removed Samples}

The shroud, thermal barrier, ducting, and tubing samples were evaluated in the laboratory using detailed metallography, transmission electron microscopy, chemical analyses, intergranular susceptibility tests, hardness profile determinations, and tensile, stress rupture, and flattening tests. Details of the samples tested, test conditions, and results are given in Ref. 10 .

Typical metallographic cross sections of Incoloy 800 superheater tubing before and after service are shown in Fig. 5-7. The sections illustrate the excellent performance of the alloy after 5 effective years service at $580^{\circ} \mathrm{C}\left(\sim 1070^{\circ} \mathrm{F}\right)$. A fairly thin, generally uniform oxide was present on the steam side. Fairly thick surface films were present on the helium side. However, there was no evidence of the occurrence of any significant interaction from the helium side. Similar results were found 


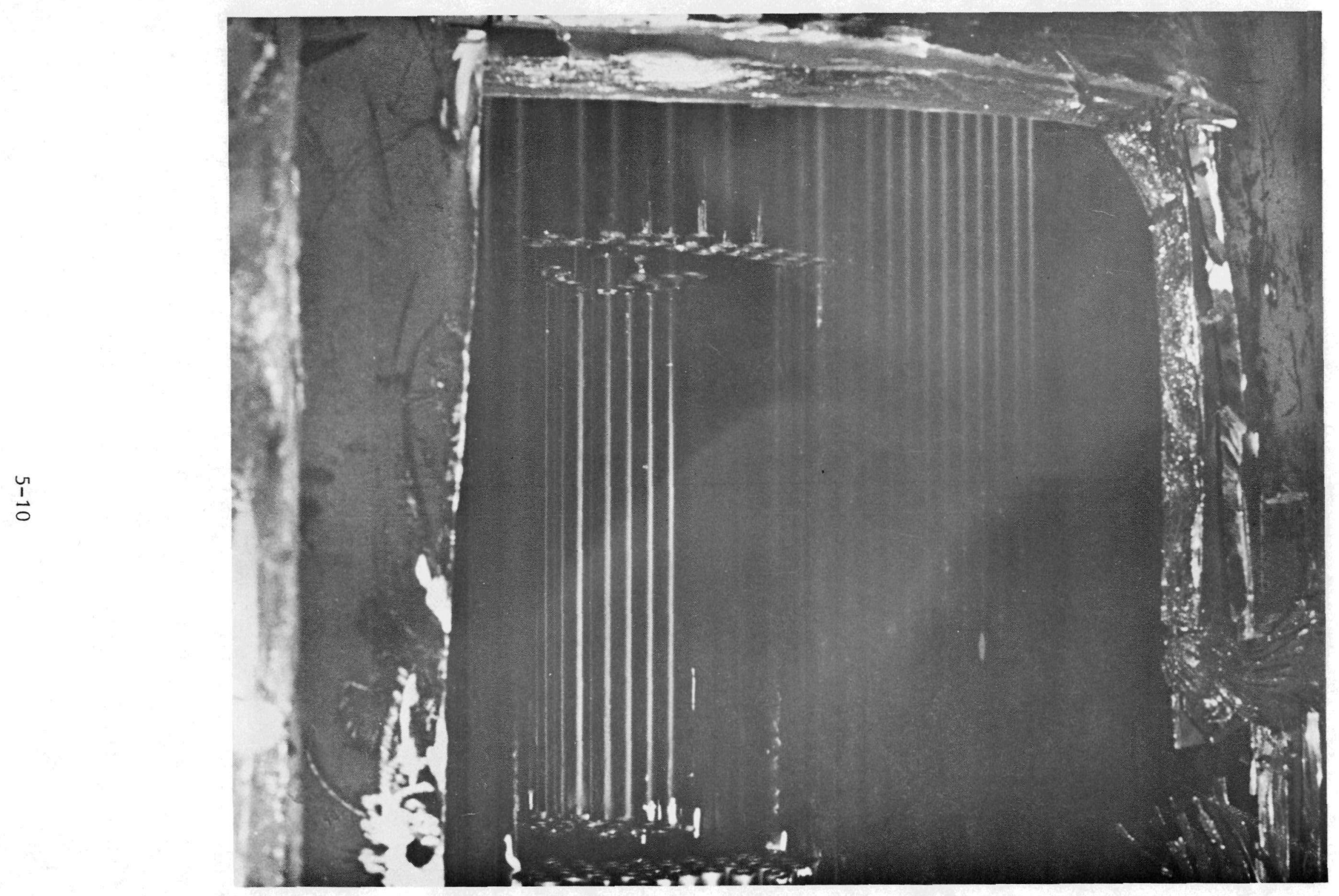

Fig. 5-4. Superheater tubes visible through hole cut through steam generator shell and shroud 

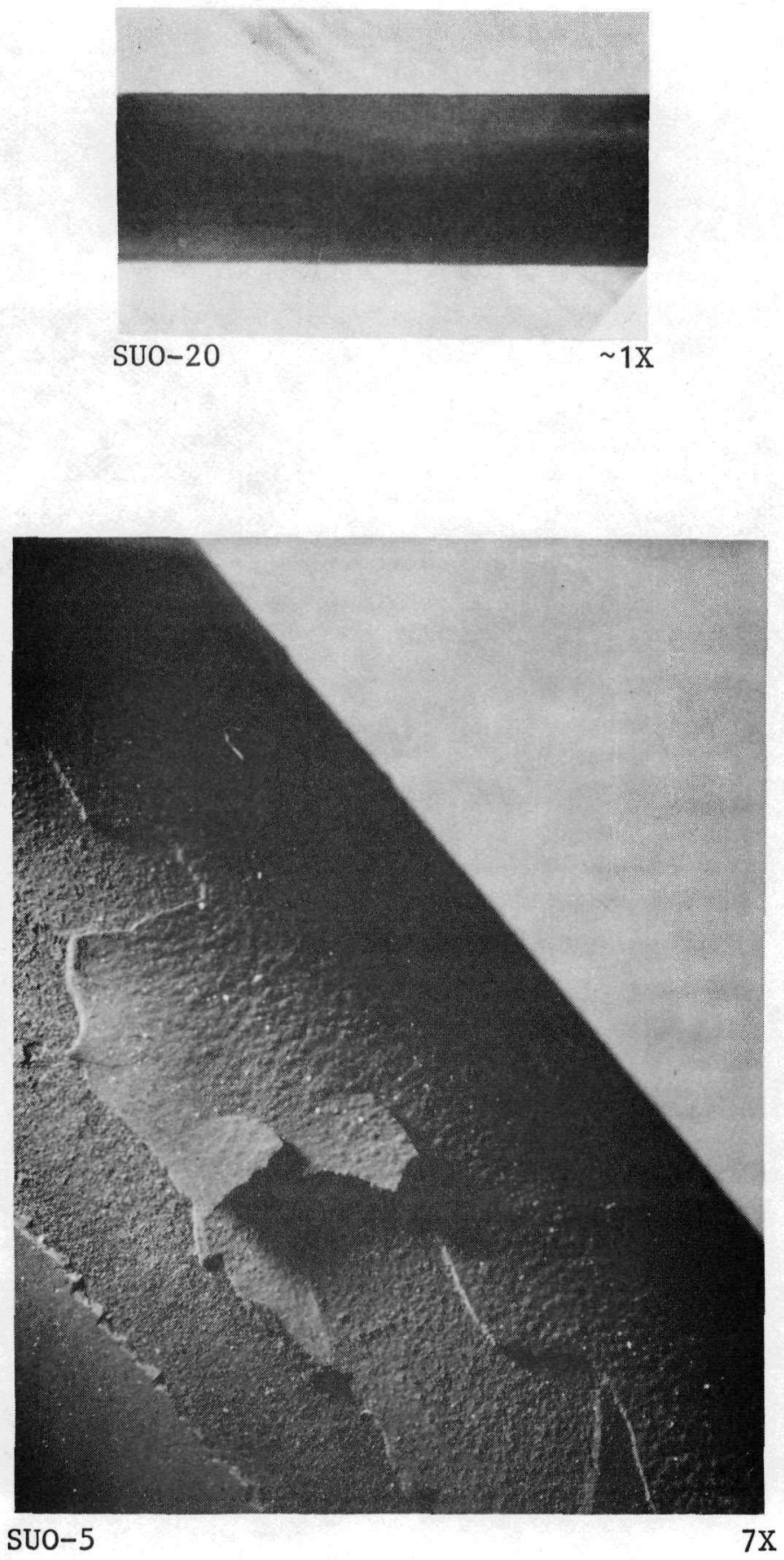

Fig. 5-5. Typical thick multilayered scale present on helium-exposed surfaces of superheater outlet tubes 


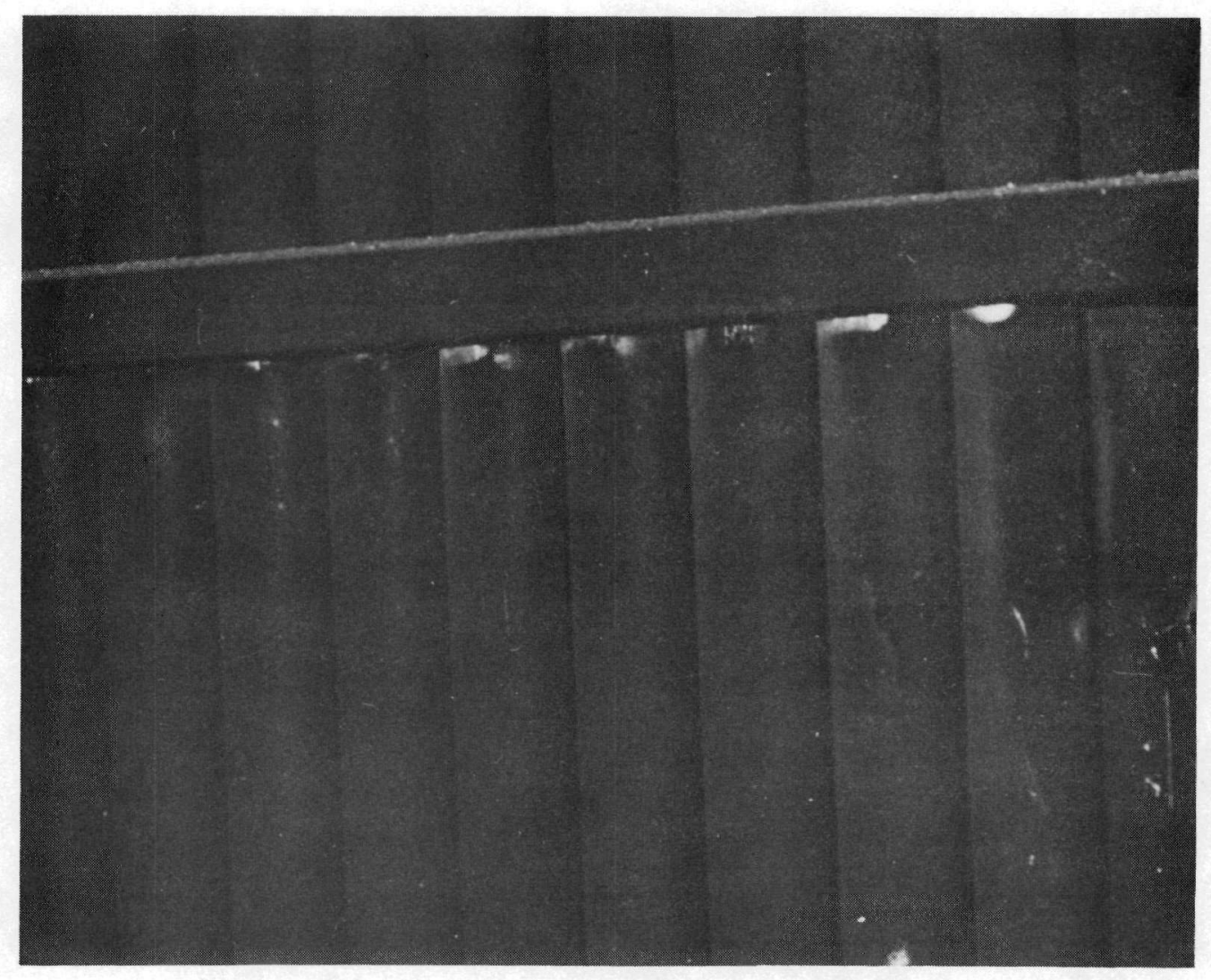

Fig. 5-6. Superheater bundle. Note wear areas where tubes pass through support plate. 


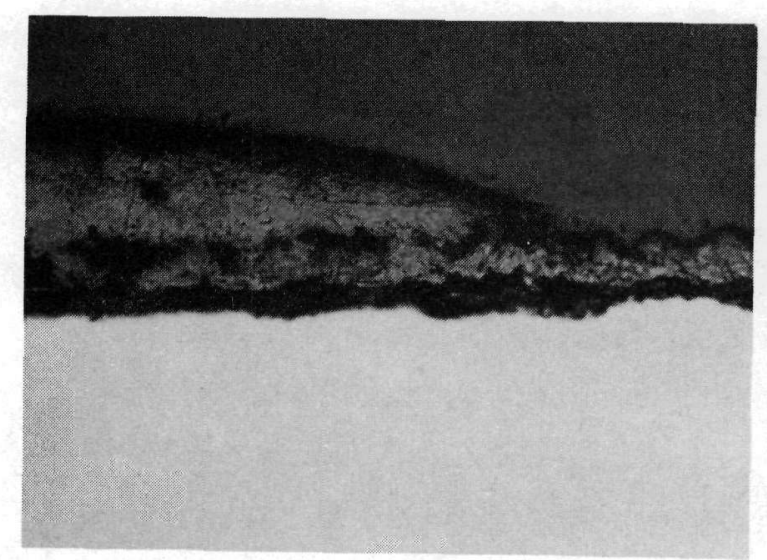

Unetched

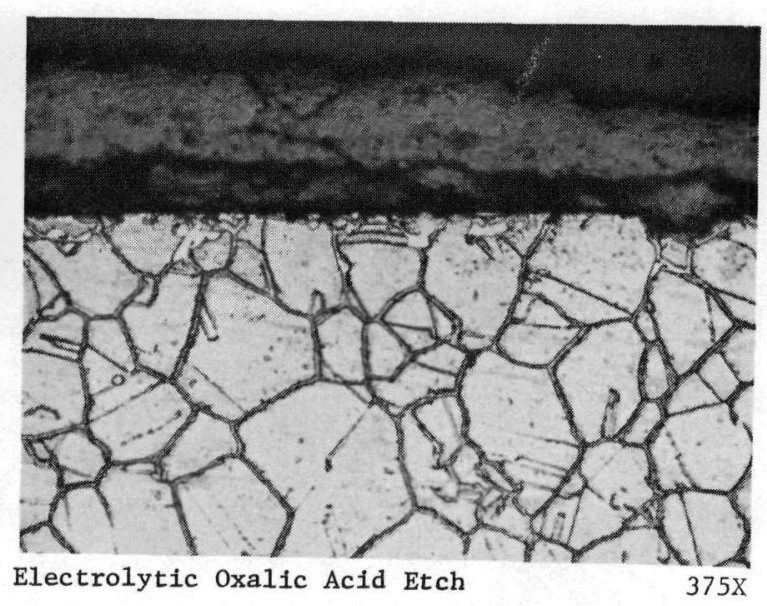

Helium Side
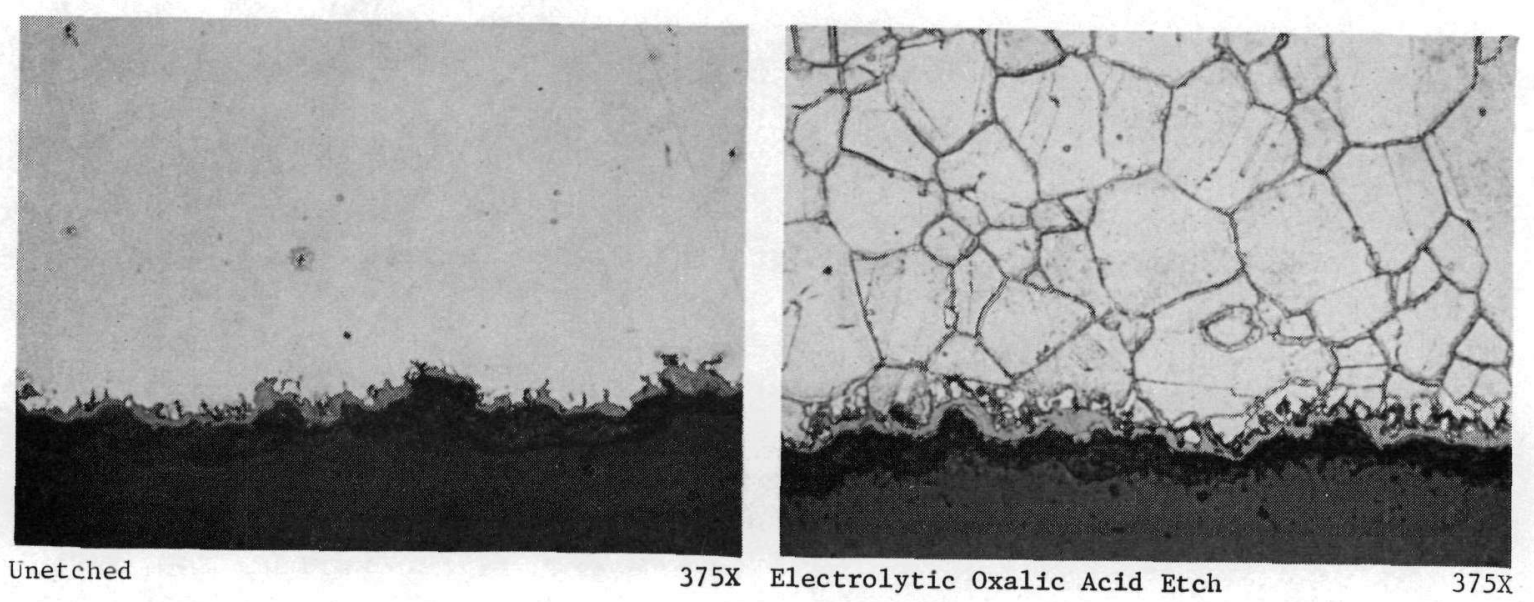

Steam Side

Fig. 5-7. Surface conditions on superheater outlet tube No. 20 (Alloy 800) 
in the economizer and evaporator carbon steel tube samples, and decarburization, although observed on both the helium and water sides, was concluded to have been due to tube fabrication rather than service. No evidence of carburization was detected by hardness measurements or chemical analyses.

Results of tensile tests performed on Incoloy 800 superheater tubes are shown in Figs. 5-8 and 5-9. These figures demonstrate that significant age hardening occurred during service, but that the tubes still retained very good ductility. This was also confirmed in subsequent flattening tests.

Overall, the observations and conclusions from metallurgical investigations can be summarized as follows:

1. The condition and metallurgical integrity of all components examined were generally excellent. There was no evidence to suggest that reactor service had caused, or was beginning to cause, unacceptable degradation of any material.

2. Interactions between primary coolant impurities and materials were generally minimal.

3. Carbon-rich surface films were present on the surfaces of all materials exposed to the helium primary coolant. In some locations (such as the superheater outlet tubing), these films were relatively thick.

4. Interactions between steam generator materials and the secondary coolant (steam/water) were minimal and generally less than predicted.

5. Significant age hardening of the Alloy 800 tubing exposed at superheater outlet temperatures occurred. The degree of 


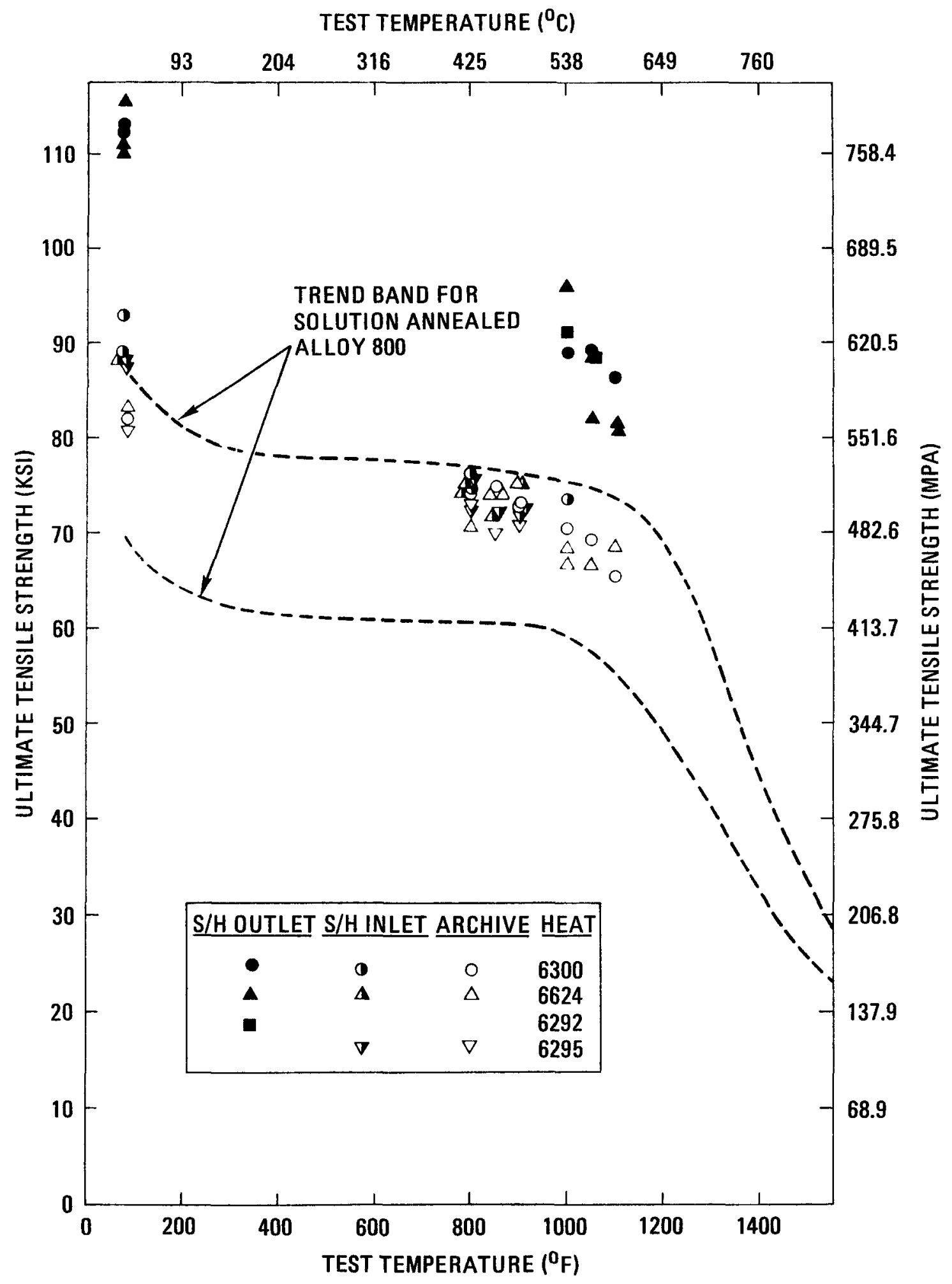

Fig. 5-8. Comparison of tensile strength data from superheater tubing with trend bands for solution-annealed Alloy 800 


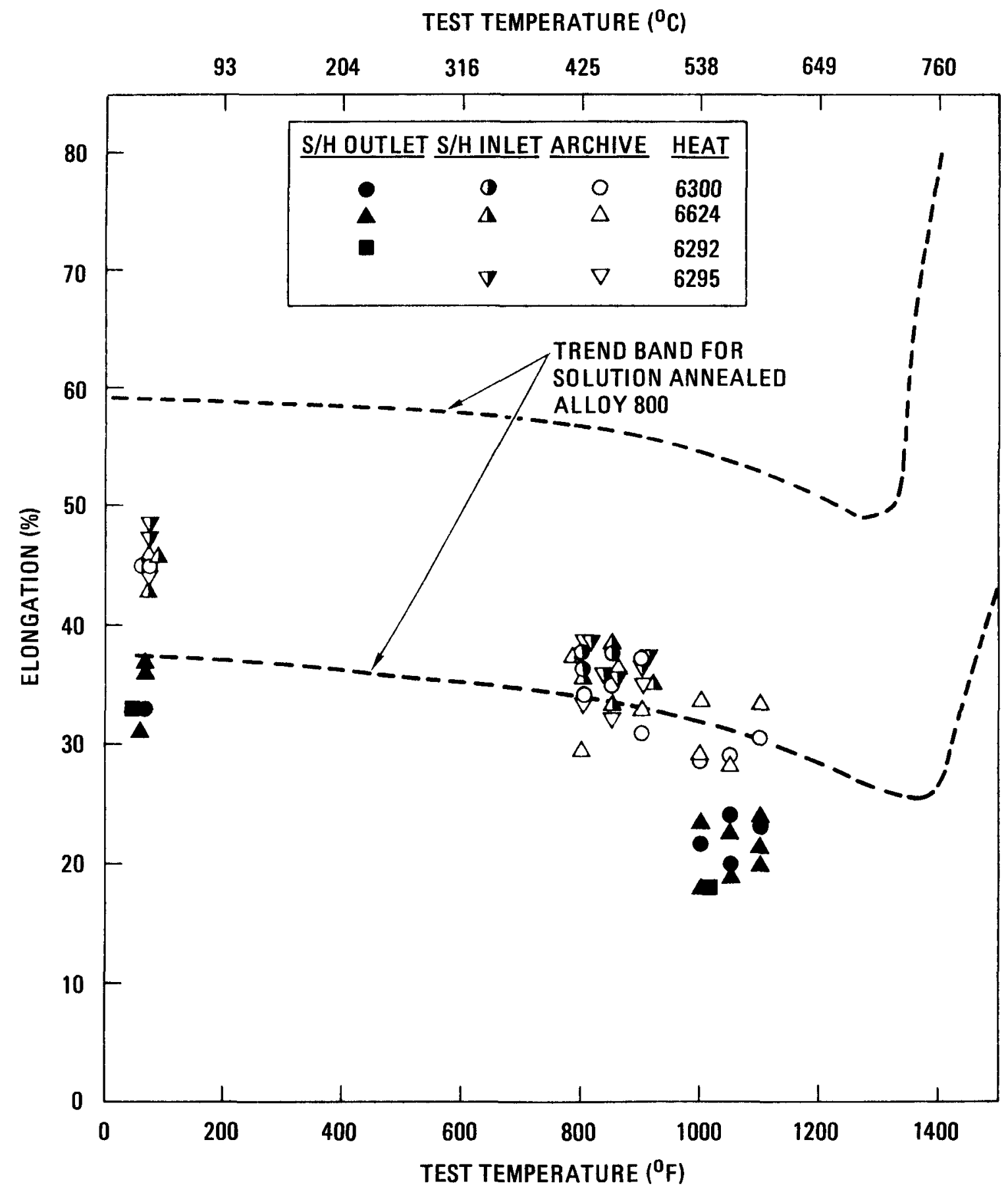

Fig. 5-9. Comparison of tensile elongation of superheater tubing (archive, inlet, and outlet) with trend bands for solution-annealed Alloy 800. [Note: Superheater tube tests were performed on sub-size specimens with a $25.4 \mathrm{~mm}$ (1 in.) gauge length. Solution-annealed Alloy 800 trend band is based on tests performed on standard size tensile specimens with a $50.8 \mathrm{~mm}$ ( 2 in.) gauge length.] 
hardening was consistent with laboratory data predictions, and residual properties were entirely acceptable from an engineering standpoint.

6. Friction and wear damage was generally minimal except for minor impact fretting observed at the superheater inlet tube/baffle plate contact points.

7. The suitability of the materials used in the construction of the Peach Bottom HTGR was confirmed, thereby verifying the materials design methods used.

\subsection{TRITIUM PERMEATION TESTS}

Tritium permeation tests were performed on selected steam generator tubing samples to establish an improved basis for modeling the tritium transport in HTGR steam generators. Specific objectives were:

1. To provide experimental data on tritium permeation through steam generator tubes that had been in service for long periods of time.

2. To assess the effect of surface films formed on either the helium-coolant side or the steam side during reactor operation on tritium permeation rate by measuring the tritium permeation rate before and after these films are removed.

3. To verify that permeation rates measured in differential laboratory experiments could be successfully extrapolated to predict integral releases from operating HTGRs.

4. To improve the accuracy of predicting tritium release in large HTGRs by using the experimental data obtained. 
Samples were obtained from the superheater, evaporator, and economizer sections of the Peach Bottom steam generator. Measurements of the tritium permeation rates were made in the operating temperature ranges of these sections, both in the as-received condition and after the surface films were removed from the helium-coolant side, the steam side, or both. The experimental apparatus employed for the tests is shown diagrammatically in Fig. 5-10. Details of this apparatus and the preparation and testing of the various samples are given in Ref. 11. The tritium source used was a simulated Peach Bottom coolant at $1.013 \times 10^{5} \mathrm{~Pa}$ (1 atm) pressure, which contained tritium and chemical impurities at partial pressures similar to those in the Peach Bottom coolant at its operating pressure $[2.330 \mathrm{x}$ $\left.10^{6} \mathrm{~Pa}(23 \mathrm{~atm})\right]$. For the Incoloy 800 superheater samples, measurements were also carried out with a simulated large HTGR coolant as the tritium source since Incoloy 800 is the reference superheater material for large HTGR steam generators.

Typical results obtained for two tubing samples are shown in Figs. 5-11 and 5-12. These results indicate the effects of surface films and tritium concentration on the tritium permeation rates through economizer and superheater tubing sections. Overall, the experimental results of the tritium permeation tests may be summarized as follows:

1. There is no significant difference between permeation rates of similar as-received samples.

2. The helium-side surface film on economizer tubes has no significant effect on tritium permeation rate (presumably since it is porous).

3. Water-side surface films decrease tritium permeation rates by approximately $10 \mathrm{X}$.

4. Increase in tritium permeation rate with tritium concentration obeys neither a linear nor a square root relationship. 


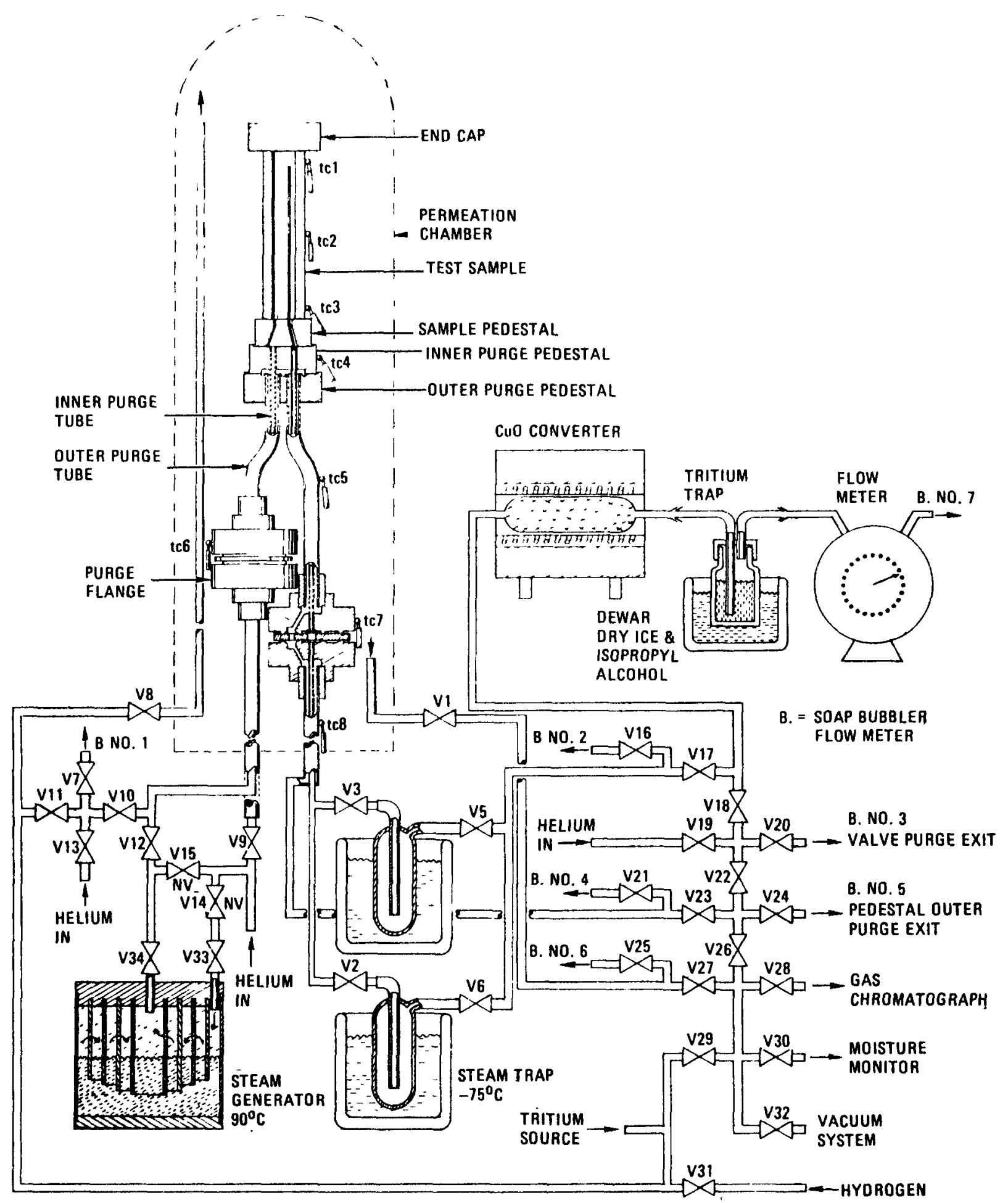

Fig. 5-10. Experimental arrangements for the study of tritium permeation through Peach Bottom steam generator tubes 


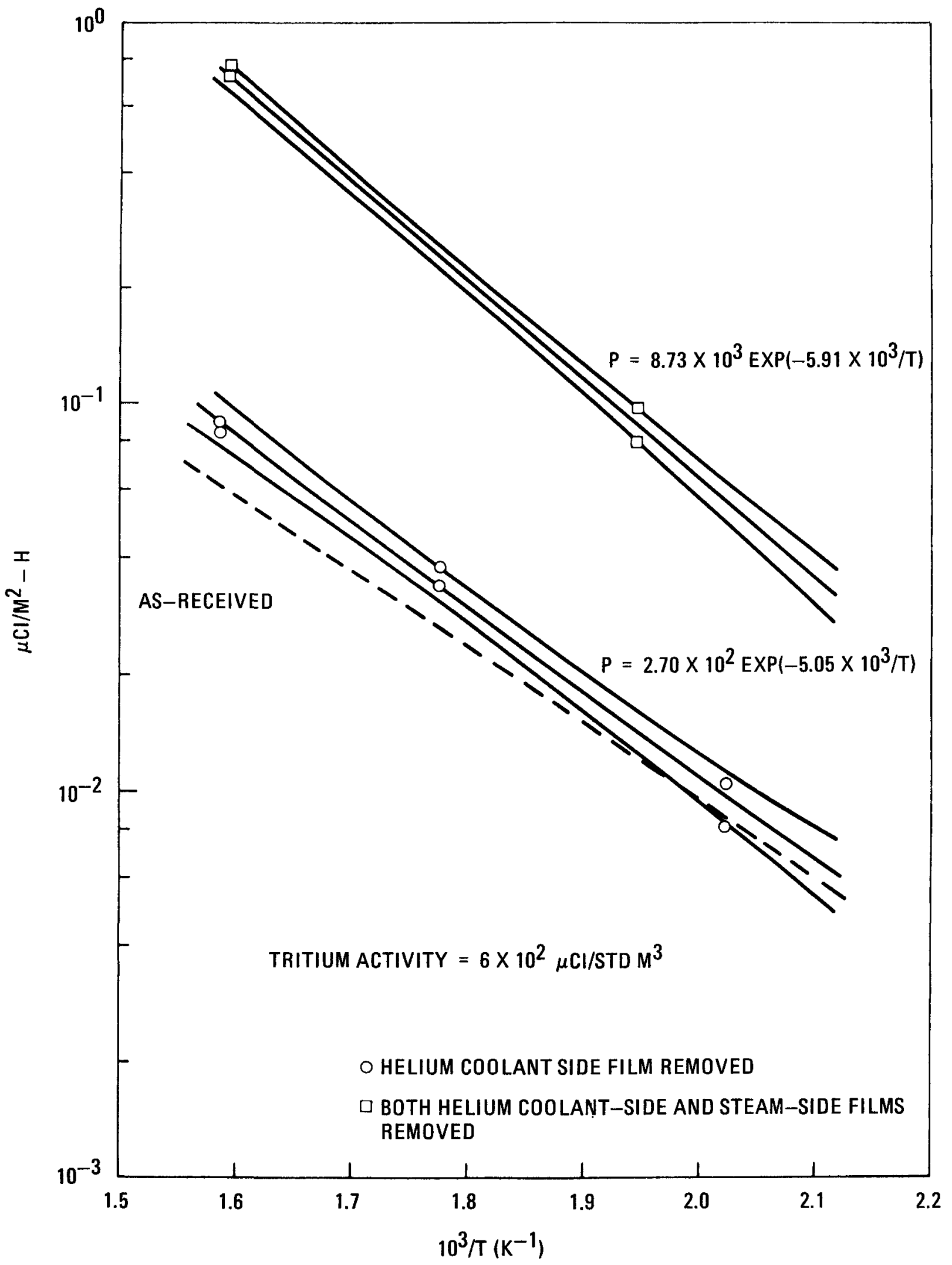

Fig. 5-11. Effect of surface films on tritium permeation rates of Peach Bottom economizer sample EC-0-76 


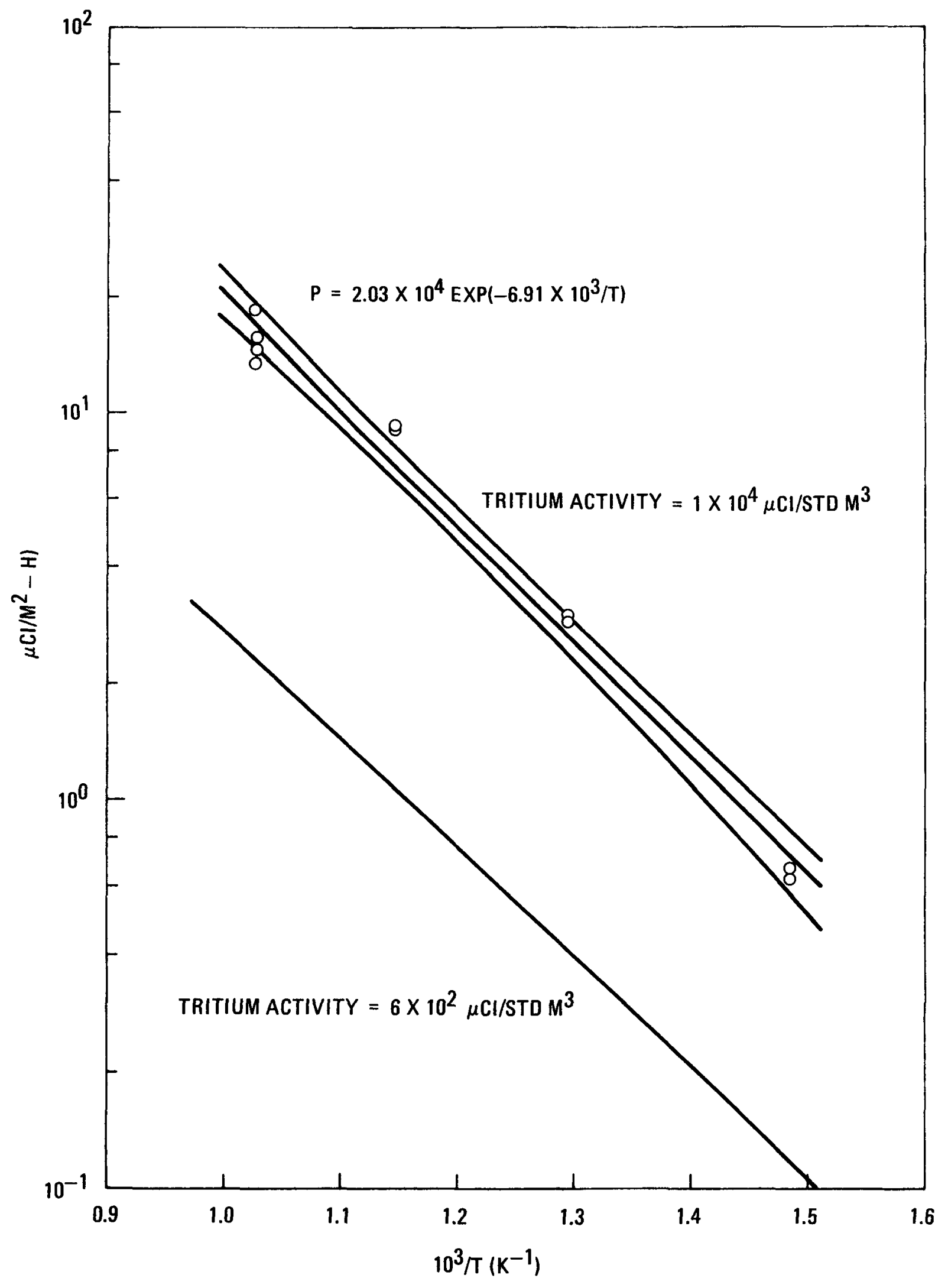

Fig. 5-12. Effect of tritium concentration on tritium permeation rate of as-received Peach Bottom superheater sample SU-0-6 
5. The permeation of tritium through HTGR steam generator tubes samples is strongly affected by the surface condition of the tubes.

By assuming a linear temperature distribution in surface temperature, and the external surface areas and operating temperatures of Ref. 12, the tritium release rate for each section of the steam generator was calculated from the measured tritium permeation rates reported in Ref. 11 by graphical integration. The results are shown in Table 5-2. The calculated total release is $1.28 \mathrm{Ci} / \mathrm{y}$, which is in good agreement with the observed value of about $1 \mathrm{Ci} / \mathrm{y}$ (Ref. 1). It is also notable that a major part of the release is contributed by the superheater section.

TABLE 5-2

CALCULATED PEACH BOTTOM TRITIUM RELEASE RATE

(HELIUM COOLANT-SIDE SURFACE FILMS IN THE AS-RECEIVED CONDITIONS)

\begin{tabular}{l|c|c}
\hline \multicolumn{1}{c|}{ Section } & $\begin{array}{c}\text { Tritium Release } \\
\text { Rate } \\
(\mathrm{Ci} / \mathrm{y})\end{array}$ & $\begin{array}{c}\text { Percent of Total } \\
\text { Release Rate }\end{array}$ \\
\hline Economizer & 0.04. & 3 \\
Evaporator & 0.34 & 27 \\
Superheater & 0.90 & 70 \\
Total & $\mathbf{1 . 2 8}$ & \\
\hline
\end{tabular}




\section{DESIGN METHODS VERIFICATION}

The major areas of HTGR design methods verification (DMV) under the PBEOL Program were nuclear, thermal, fission products, and materials. Nuclear DMV (Section 6.1) has already been addressed briefly in the initial comparisons of fuel gamma scan results with the calculations. Structural material adequacy for intended applications has been discussed and demonstrated in Section 5.2 and is not therefore called out as a separate section here.

\subsection{NUCLEAR AND THERMAL DESIGN METHODS VERIFICATION}

\subsubsection{Nuclear Performance Correlations}

Verification of nuclear physics design methods was performed by comparing measured axial and radial power distributions with design code predictions. Calculations were performed using the GAUGE and BUG R-Z computer codes.

Inventories of short- and long-lived isotopes obtained by gamma scanning were used to establish EOL and time-averaged axial power profiles, respectively. Since Cs-137 has a half-life of 30.1 years, the Cs-137 distribution was representative of the time-averaged axial power profile in elements in which there was no cesium redistribution. The distributions of Zr-95 (half-1ife of 65 days) and La-140 (effective half-1ife of 12.8 days because of $\mathrm{Ba}-140$ precursor) were representative of the EOL axial power profile in elements unperturbed by contro1 rod movements.

The Cs-137, Zr-95, and La-140 concentratons were a1so used to establish radial power distributions. Using the mean activities of these isotopes, time-averaged and EOL radial power profiles were determined for 
Peach Bottom Core 2. In addition, because of no discernible Cs-137 loss from the elements (with measurement accuracy), the total Cs-137 inventory was used to calculate an element average fuel burnup which was directly proportional to the element average power.

The comparison between actual and predicted axial power profiles in Core 2 is shown in Fig. 6-1. A summary of normalized radial distributions for Peach Bottom Core 2 is shown in Fig. 6-2. The conclusions from these figures and the associated investigations were as follows:

1. Power shape and shift in power peak from midplane toward the top of the core with depletion were correctly modeled although the shift in peak was slightly overpredicted.

2. Agreement between measured and predicted time-averaged and EOL axial profiles was found to be within $\pm 7.4 \%(1 \sigma)$, which was well within the $\pm 8 \%$ to $13 \%$ accuracy quoted for other nuclear reactors.

3. Radial power distributions were verified within $\pm 6.8 \%(1 \sigma)$, which is within the predictive accuracy of $\pm 3 \%$ to $8 \%$ reported for other reactor systems.

4. For the core average, agreement between predicted and measured burnup (via Cs-137 inventory) was found to be within $\pm 0.7 \%(1 \sigma)$.

5. The combined uncertainty for radial and axial power predictions for the Peach Bottom HTGR was $\pm 10 \%$ (10) compared to $\pm 8 \%$ to $15 \%$ deduced for other reactor systems. This confirms the validity of the nuclear physics design methods used.

\subsubsection{Thermal Performance Correlations}

Verification of thermal design methods was performed by comparing observed Peach Bottom fuel element temperatures with those calculated using a modifled version of TREVER, a one-dimensional heat transfer code. The 

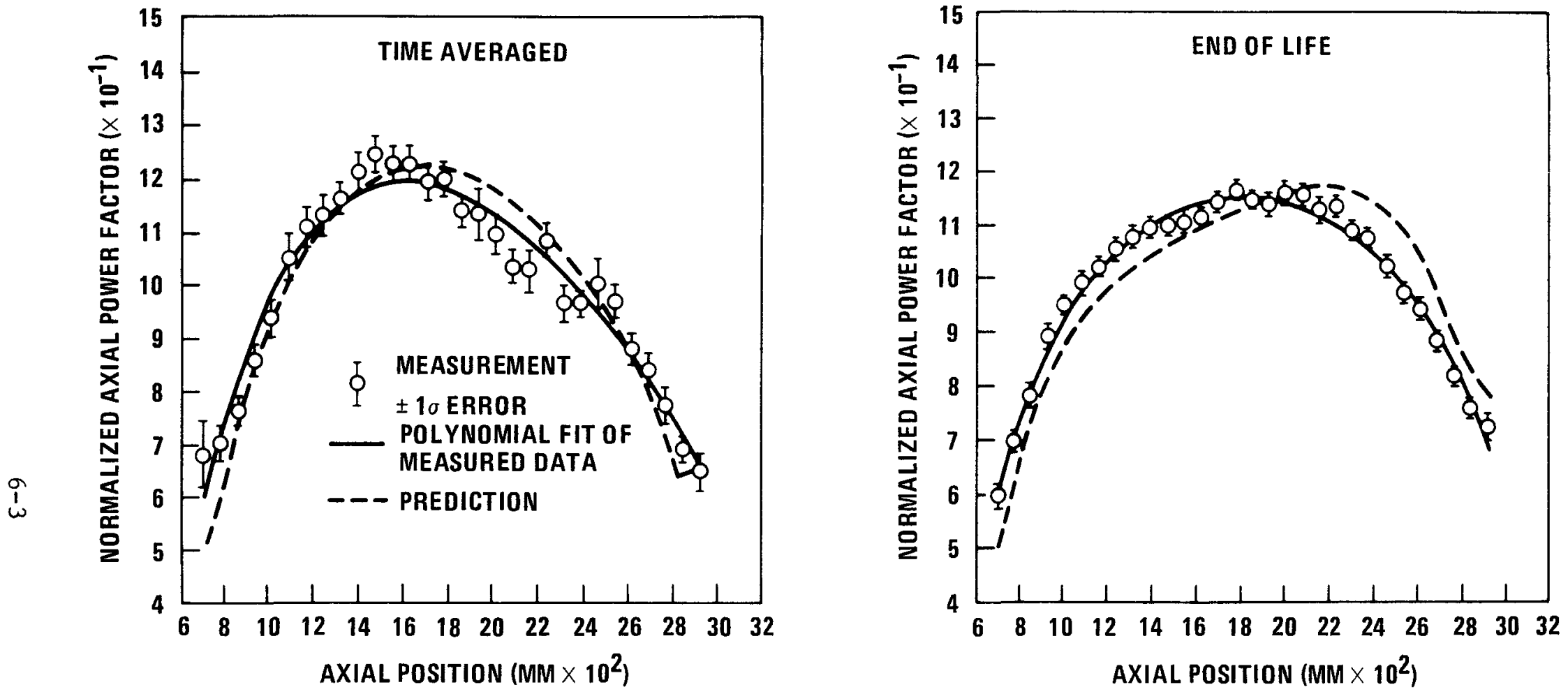

Fig. 6-1. Comparison of measured and predicted unrodded axial power profiles for Peach Bottom Core 2 


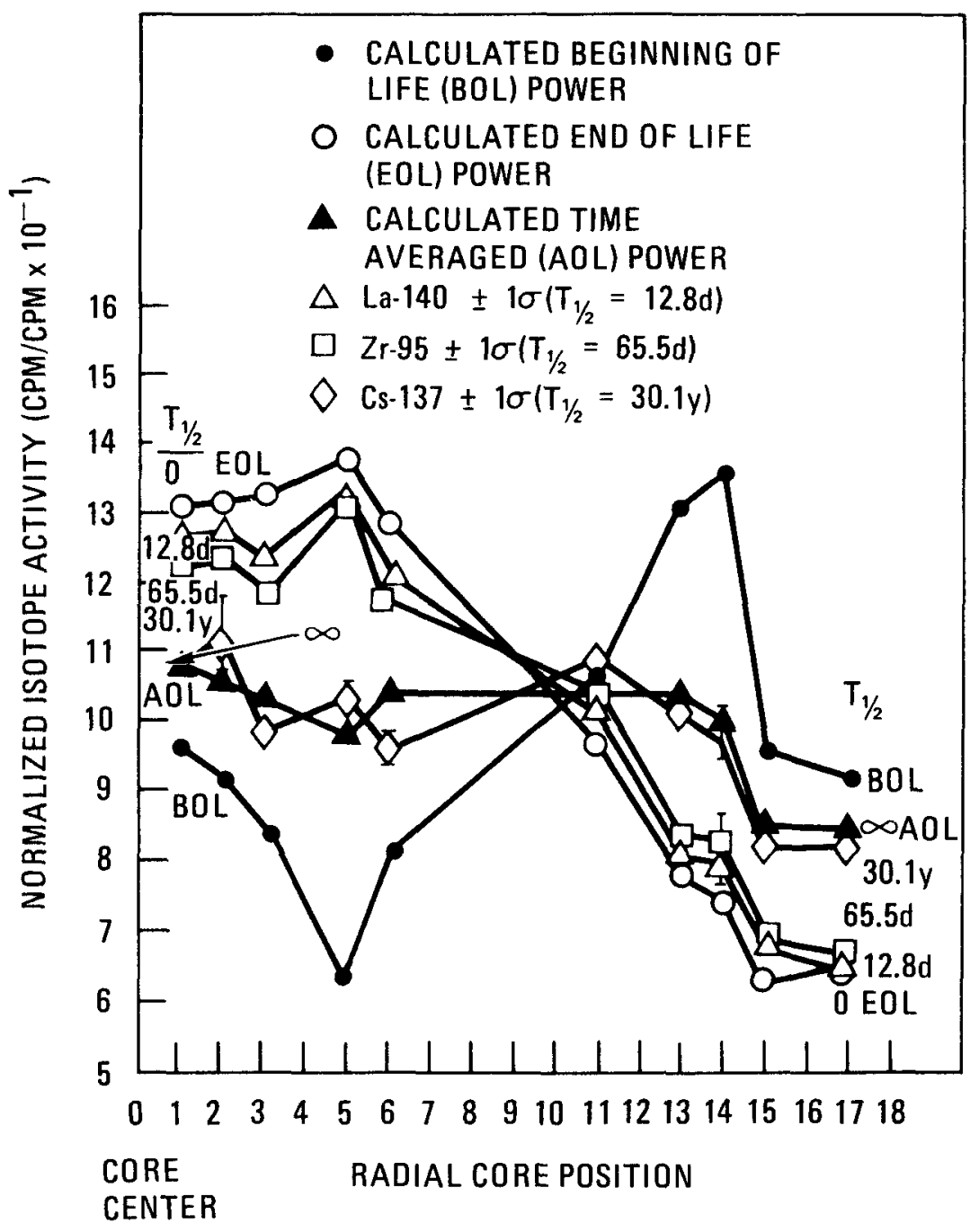

Fig. 6-2. Normalized radial isotope distribution for Peach Bottom Core 2 
code was set up to perform thermal calculations at 30 axial nodes corresponding to the center of each fuel compact in a Peach Bottom fuel element. In the TREVER analysis, the history of Peach Bottom Core 2 was simulated by 23 time points which divided it into 22 intervals of steady-state operation. The core power, flow rate, and inlet helium pressure and temperature for each of the TREVER time intervals were obtained by averaging the hour-by-hour information recorded for Core 2 . The physics data required as input to the thermal analysis included element average power factors, fast neutron fluence, axial power profiles, and flux profiles. Other important data utilized by the TREVER code were the thermal conductivity, irradiation strain, and thermal strain of both the fuel element sleeve and the fuel compact. It was necessary to develop a fuel compact irradiationinduced radial strain correlation based on fuel compact metrology data to provide these latter inputs. Use of this correlation in subsequent thermal calculations permitted reasonable modeling of the radial gap changes between the fuel compact, spine, and sleeve during irradiation.

Measured temperatures were provided by 17 driver fuel elements and 24 fuel test elements which were instrumented with two thermocouples each of the tungsten-rhenium (W/Re) or Chromel-Alumel (C/A) type. Each thermocouple effectively measured maximum fuel compact temperature at the plane of the hot junction, whereas test element thermocouples measured maximum and minimum graphite body temperatures. The average lifetime of these thermocouples was about $50 \%$ of full irradiation exposure, and failure temperatures were observed to be approximately $1200^{\circ} \mathrm{C}$ and $1400^{\circ} \mathrm{C}$ for the C/A and W/Re type, respectively. A W/Re thermocouple decalibration correlation with thermal fluence and fluence gradient, previously determined on six $\mathrm{W} / \mathrm{Re}$ test element thermocouples, was factored into $\mathrm{W} / \mathrm{Re}$ measured temperatures. The maximum measured thermocouple temperature in a driver element was determined to be $1230^{\circ} \mathrm{C}$ although peak temperatures of $1500^{\circ} \mathrm{C}$ were predicted toward the EOL when the majority of thermocouples had already failed. 
A total of 180 comparisons between measured and predicted temperatures in 14 different driver fuel elements were obtained; typical comparisons are shown in Fig. 6-3. The major conclusions were as follows:

1. Agreement between measured and calculated temperatures was found to be within $\pm 87^{\circ} \mathrm{C}(1 \sigma)$ with an apparent bias of $+27^{\circ} \pm 7^{\circ} \mathrm{C}(1 \sigma)$ in the prediction.

2. The likely causes for this general overprediction of temperature are eccentricity of the radial sleeve - fuel compact gap and an underestimation of the fuel thermal conductivity.

3. The observed predictive accuracy of $\pm 87^{\circ} \mathrm{C}$ is consistent with the $\pm 10 \%$ random variation in the local power predictions deduced from the nuclear design verification.

4. The predictive accuracy of the thermal design verification was found to be well within the limits determined for other nuclear reactor systems. This confirms the validity of HTGR design methods for such thermal predictions.

Details of both the nuclear and thermal design verification techniques, methodology, and results appear in Refs. 13 and 14.

\subsection{FISSION PRODUCT DESIGN METHODS VERIFICATION}

\subsubsection{Fission Gas Release Correlations}

Verification of HTGR design methodology for fission gas release was performed by comparing actual Peach Bottom operating data from Core 2 with design code predictions for noble gas release into the purge stream using the PERFOR code. Fission gas release results from as-manufactured, heavy metal contamination and in-service particle failure. The total $\overline{\mathrm{R} / \mathrm{B}}$ (release rate/birth rate) for nuclide $i$ is given by: 

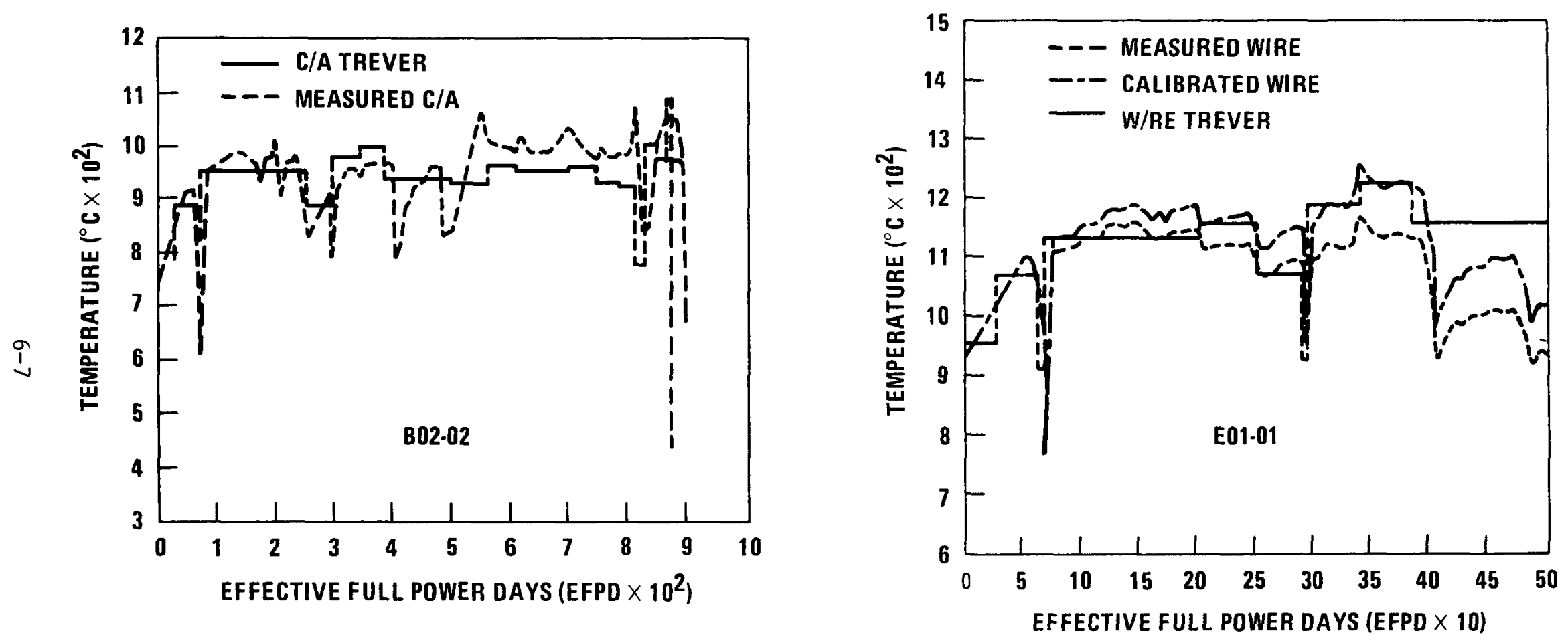

Fig. 6-3. Comparison of calculated and measured temperatures for Peach Bottom driver fuel elements B02-02 and E01-01 


$$
(\overline{R / B})_{i}=(R / B)_{i}^{a m}+F(R / B)_{i}^{f}
$$

where the superscripts am and $f$ refer to as-manufactured and failed, respectively, and $F$ is the fraction of fissions in failed particles. Two archive compacts were activated in TRIGA to measure $(R / B){ }_{i}^{a m} ;(R / B){ }_{i}^{f}$ for failed particles was known from extensive past investigations. Both $(\mathrm{R} / \mathrm{B})_{i}^{\text {am }}$ and $(\mathrm{R} / \mathrm{B})_{i}^{\mathrm{f}}$ are exponentially temperature-dependent and were assumed to vary as the square root of isotope half-life. Analytical models were developed to predict particle failure as functions of time, temperature, and fluence. Three failure mechanisms were considered: manufacturing defects, pressure vesse1, and kerne1 migration. PERFOR code modifications were also performed to account for the single particle fuel, cylindrical fuel element geometry, and a batch-loaded core. The reactor operating history was approximated by 22 constant-power time intervals. Detailed core-survey calculations were performed to predict core-average failure fractions and $\overline{\mathrm{R} / \mathrm{B} S}$ for $\mathrm{Kr}-85 \mathrm{~m}$ and $\mathrm{Xe}-138$; the $\overline{\mathrm{R} / \mathrm{B} S}$ for other isotopes were obtained by extrapolation with the assumed half-life dependence.

The calculated and measured $\mathrm{R} / \mathrm{Bs}$ (release rate into purge divided by birth rate in the fuel) for the reference nuclides $\mathrm{Kr}-85 \mathrm{~m}$ and $\mathrm{Xe}-138$ are compared in Fig. 6-4; the agreement is excellent and well within design margins (by a factor of 25 ). Gaseous release into the primary coolant was a factor of 5000 less than into the purge; the design circulating inventory ( $4225 \mathrm{Ci}$ ) proved highly conservative, as the actual value never exceeded $1 \mathrm{Ci}$ throughout Core 2 operation. To further confirm performance predictions, a series of fuel compacts recovered from spent fuel elements was re-irradiated in the GA TRIGA reactor to determine the release characteristics of individual compacts; despite some scatter, these results were also consistent with calculations.

Overall, the conclusions may be summarized as follows:

1. Core 2 gaseous release was accurately predicted, especially considering the uncertainties in the input data and the limited 


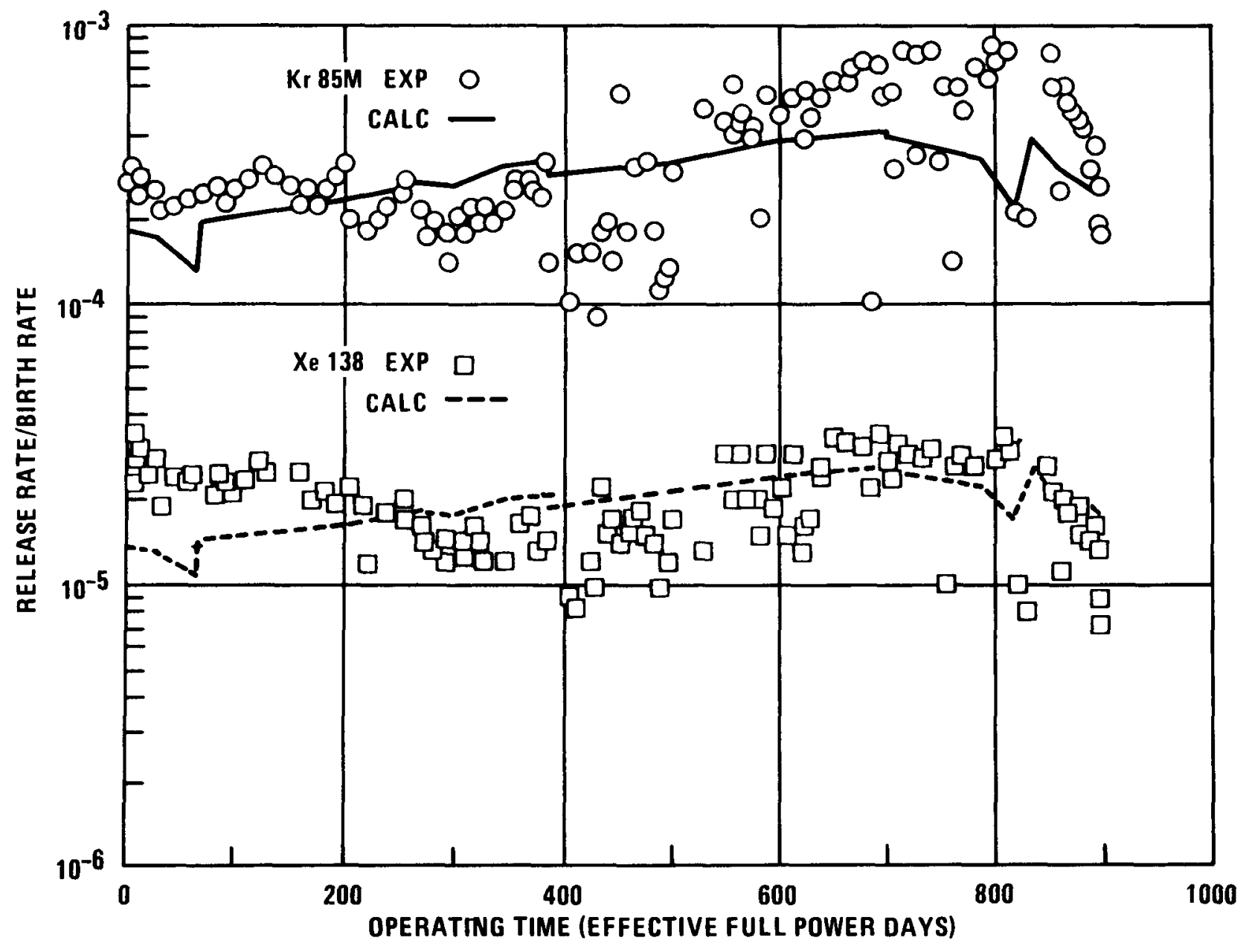

"RELEASE RATE INTO PURGE - RELEASE RATE INTO

PRIMARY COOLANT WAS LOWER BY FACTOR OF $\sim \mathbf{5 0 0 0 .}$

Fig. 6-4. Comparison of measured and calculated fission gas release from Peach Bottom Core 2 
resolution of NaI detectors. The largest deviation for $\mathrm{Kr}-85 \mathrm{~m}$ was a factor of 2.5 underprediction near EOL. (Such predictions for large HTGRs contain a safety factor of five.)

2. The observed dependence of $R / B$ on half-life ( 0.66 power for krypton and 0.60 for xenon) was greater than the expected 0.5 power, but measurement errors were suspected. Even so, the release of all observed isotopes was predicted to well within design margins.

3. Core 2 gaseous release throughout life was predominantly from contamination; even at EOL, with a calculated failure fraction of $0.9 \%$, only $15 \%$ of the predicted release was from failed particles. Levels of contamination in Core 2 fuel were high ( $4.3 \times 10^{-3}$ fraction exposed uranium) relative to the current fuel specification of $\leq 10^{-4}$. (With the fuel element purge system, there was no incentive to impose tight specifications on Peach Bottom fuel.)

4. The calculated average EOL failed particle fraction was $0.9 \%$, proving that the BISO particles performed well to full design burnup. Predicted failure fractions appear accurate within a factor of 2, based on the limited data available.

5. The results verified the fission gas release design methodology current1y applied to large HTGRs.

Further details of the fission gas release design verifications performed appear in Refs. 15 and 16.

\subsubsection{Fission Metal Release and Transport Correlations}

Verification of fission metal release and transport was performed by comparison of fission product distributions and inventories determined 
in fuel element PIEs at ORNL with FIPER code predictions. Measured total core release was also compared with FIPER code predictions.

Major revisions to the large HTGR FIPER $Q$ code were necessary in order to adequately model the Peach Bottom fuel element geometry and materials. The revisions included simulation of the helium purge flow, proper modeling of partition coefficients and diffusive release, and modifications to correct numerical stability problems of nonconvergence. All of these modifications contributed to major delay in operability of the code, precluding a complete analysis and understanding of all available data within the contract budgetary and schedule limitations.

Analyses and comparisons were made for six PIE fuel elements. Comparison areas included axial and radial profiles for cesium and strontium in the element spine, fuel compacts, and sleeve; metallic inventories in these locations; and $C s$ and $S r$ release into the purge stream and primary circuit. Total core release was estimated from the six PIE elements and three additional elements. Sensitivity studies were performed to assess effects of diffusion coefficients, fuel thermal conductivity, operating temperature, and power.

Typical results from the analyses are shown in Figs. 6-5 through 6-7; the conclusions may be summarized as follows:

1. The effect of axial purge flow, including removal of fission products from the hotter locations of the fuel element and subsequent deposition in cooler locations, was adequately modeled with the FIPER code (Fig. 6-5).

2. The rate of migration through graphite was underpredicted (Fig. 6-6). This is thought to be due to use of bulk material diffusion coefficients and a single rather than multiple path transport model. 


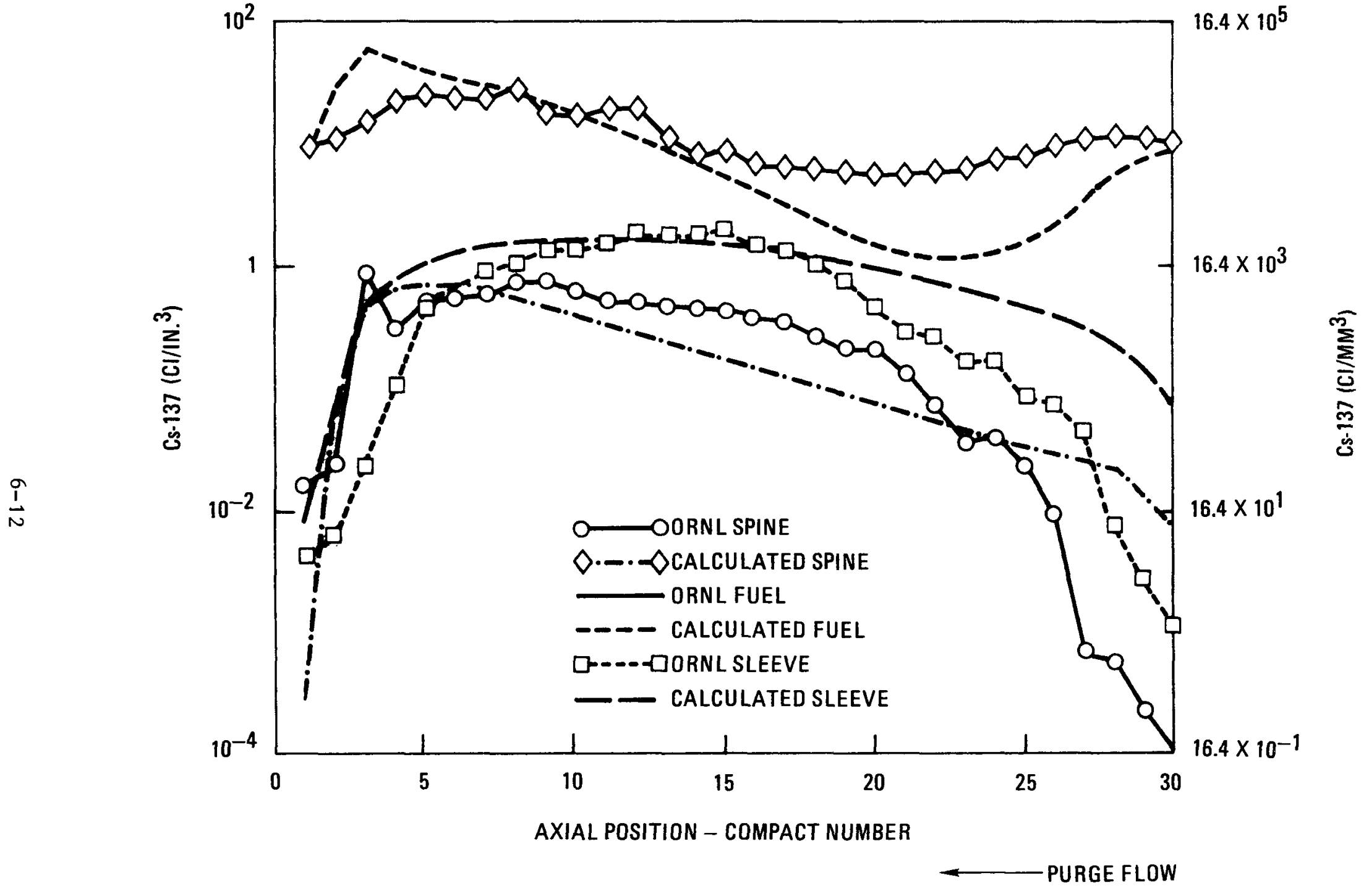

Fig. 6-5. Axial Cs-137 distribution in Peach Bottom E01-01 


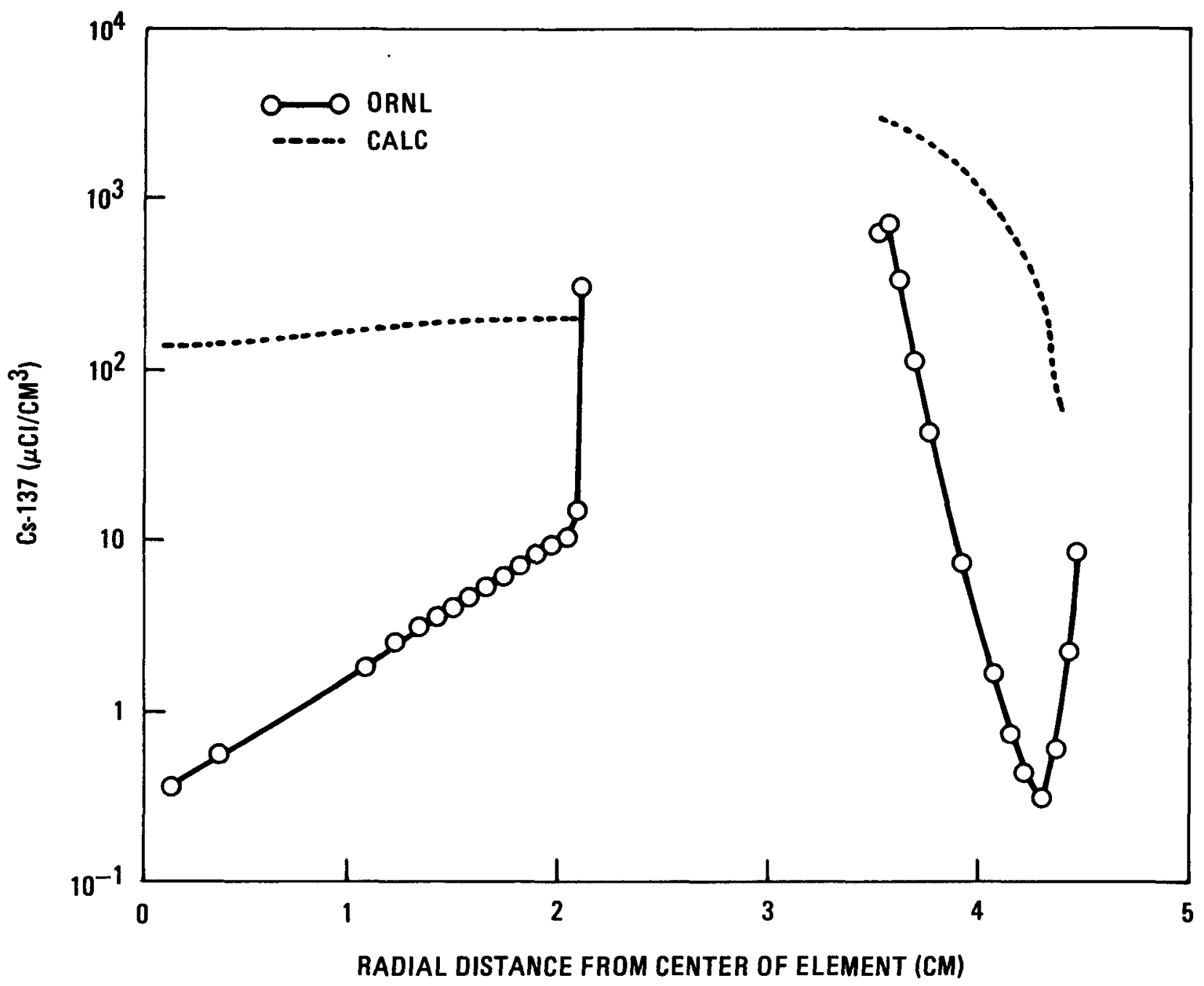

Fig. 6-6. Cs-137 in Peach Bottom compact 28, E01-01 


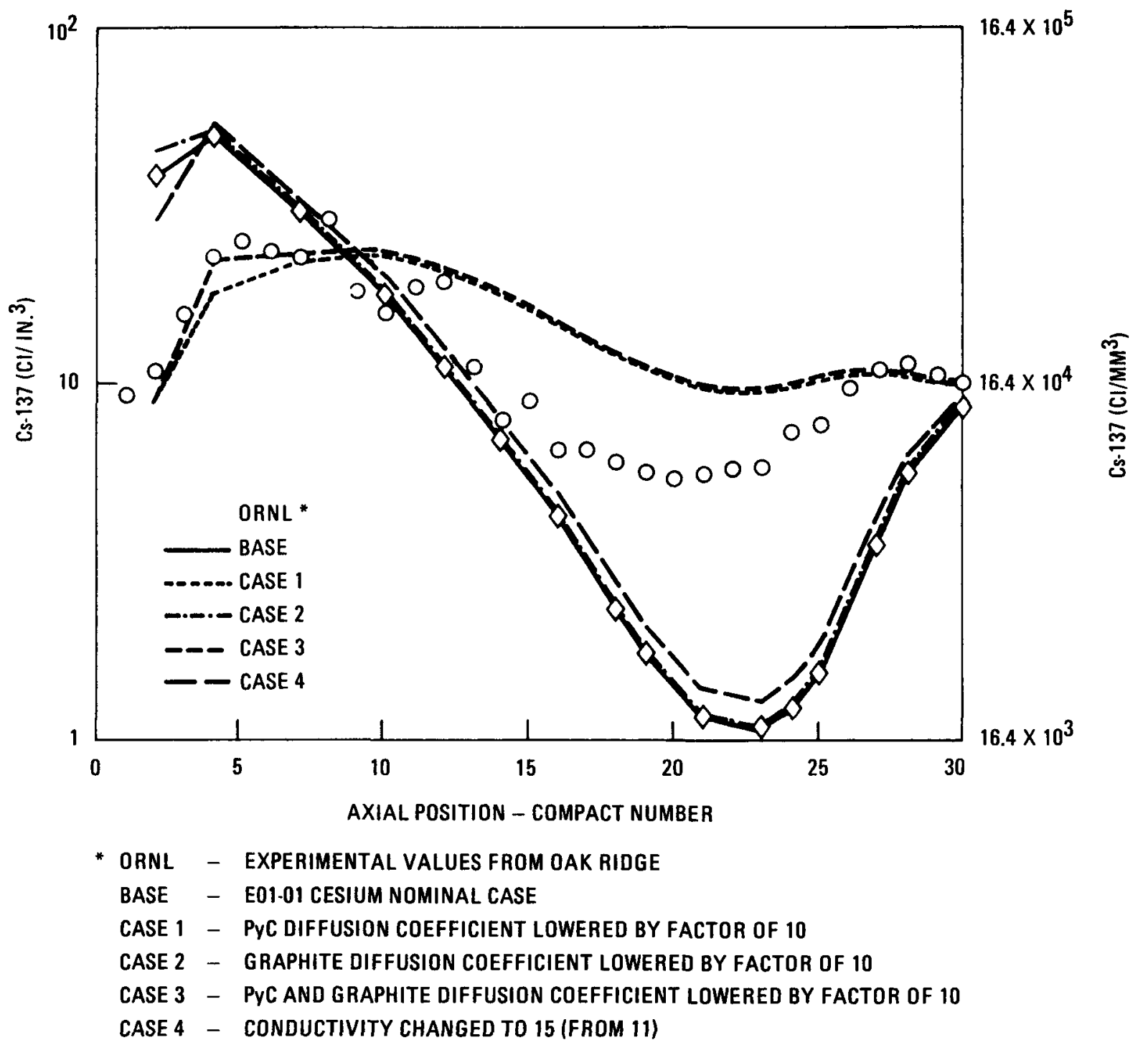

Fig. 6-7. Sensitivity study on cesium in Peach Bottom E01-01 
3. Fission metal concentrations at graphite surfaces were not satisfactorily predicted, probably due to the nonuniform impregnation of the graphite sleeves during manufacture.

4. Fission metal release from the fuel particles was overpredicted; the total core release of $\mathrm{Cs}-137$ was also overpredicted by a factor of approximately 15 using reference material property data taken on large HTGR materials. When the diffusion coefficient measured for actual Peach Bottom graphite was used, the total core Cs release was substantially underpredicted.

5. Sensitivity studies indicated that small changes in diffusion coefficients could markedly change predicted releases. Also lowering temperatures by $50^{\circ} \mathrm{C}$ considerably improved axial fission metal distributions and metallic migration predictions.

6. The overall results indicate the need for better physical modeling of fission metal release and migration as applied to Peach Bottom fuel elements, together with the need for more accurate material properties data.

Detailed discussions of the model changes necessary, the analyses performed, and the results obtained in this design verification study are presented in Ref. 16.

\subsubsection{Fission Product Plateout Distribution Correlations}

Verification of fission product plateout distribution predictions was performed by comparing actual specific activity distributions from circuit gamma scans and subsequent radiochemistry on removed samples with PAD code plateout predictions. Code modeling and data correlation problems had to be solved, however, prior to making the comparisons. These problems included the following: 
1. Construction of an appropriate one-dimensional model of the primary circuit.

2. Accurate representation of the steam generator tube bundles (which contained much of the deposited activity).

3. Calculation of plateout under essentially constant operating conditions ( $95 \%$ power, $105 \%$ flow) and EFPD rather than real time.

4. Collapsing of experimental profiles in the steam generator into one dimension by axial and radial averaging.

The complete experimental and predicted cesium plateout distributions are compared in Fig. 6-8, the format of which is the PAD code representation of the Peach Bottom primary circuit. The figure includes both the collapsed steam generator data and the duct scan data. The specific activity is plotted as a function of fractional cumulative surface area. Two PAD calculations are shown: (1) mass-transfer controlled (i.e., the surfaces are perfect sinks for cesium), and (2) sorptivity controlled (adsorption isotherms are used to describe the sorptive capacity of the surfaces as functions of temperature and partial pressure). In both cases, the time-average core release rate of cesium was adjusted so that the predicted specific activity at the evaporator inlet (shell side) was approximately equal to the measured value $\left(\sim 5 \mu \mathrm{Ci} / \mathrm{cm}^{2}\right)$.

The experimental plateout measurements from the cold ducts are shown in greater detail in Figs. 6-9 and 6-10, along with the predicted profiles (here the perfect sink and sorptivity control cases are identical). The IRT data are shown together with the ORNL end-of-life external scans and the gamma scans of the destructively removed trepan samples. The results of the internal scans compared with the predicted plateout distribution are also shown in Fig. 6-10. 


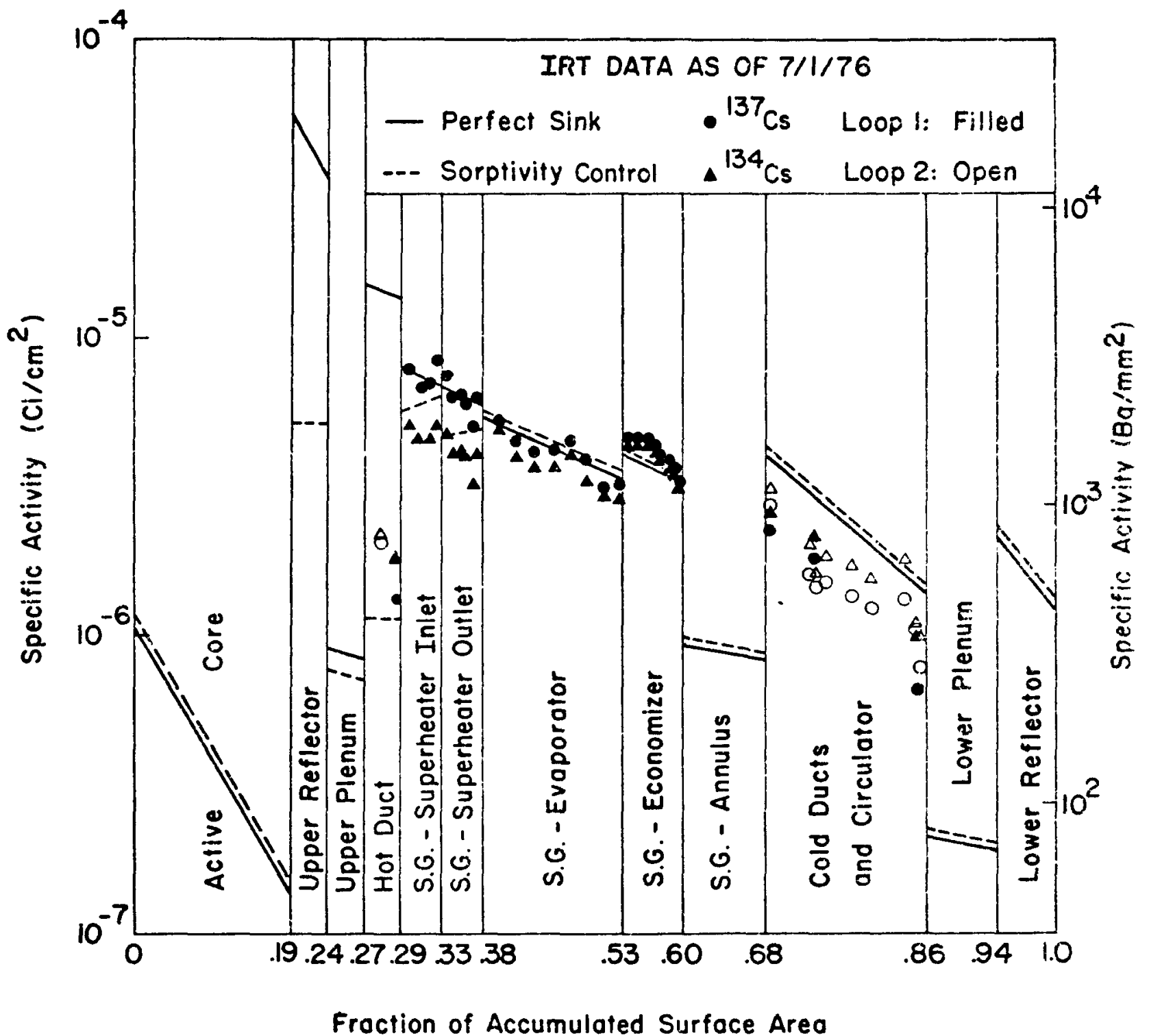

Fig. 6-8. Plateout distribution of $\mathrm{Cs}-137$ and $\mathrm{Cs}-134$ in Peach Bottom HTGR 


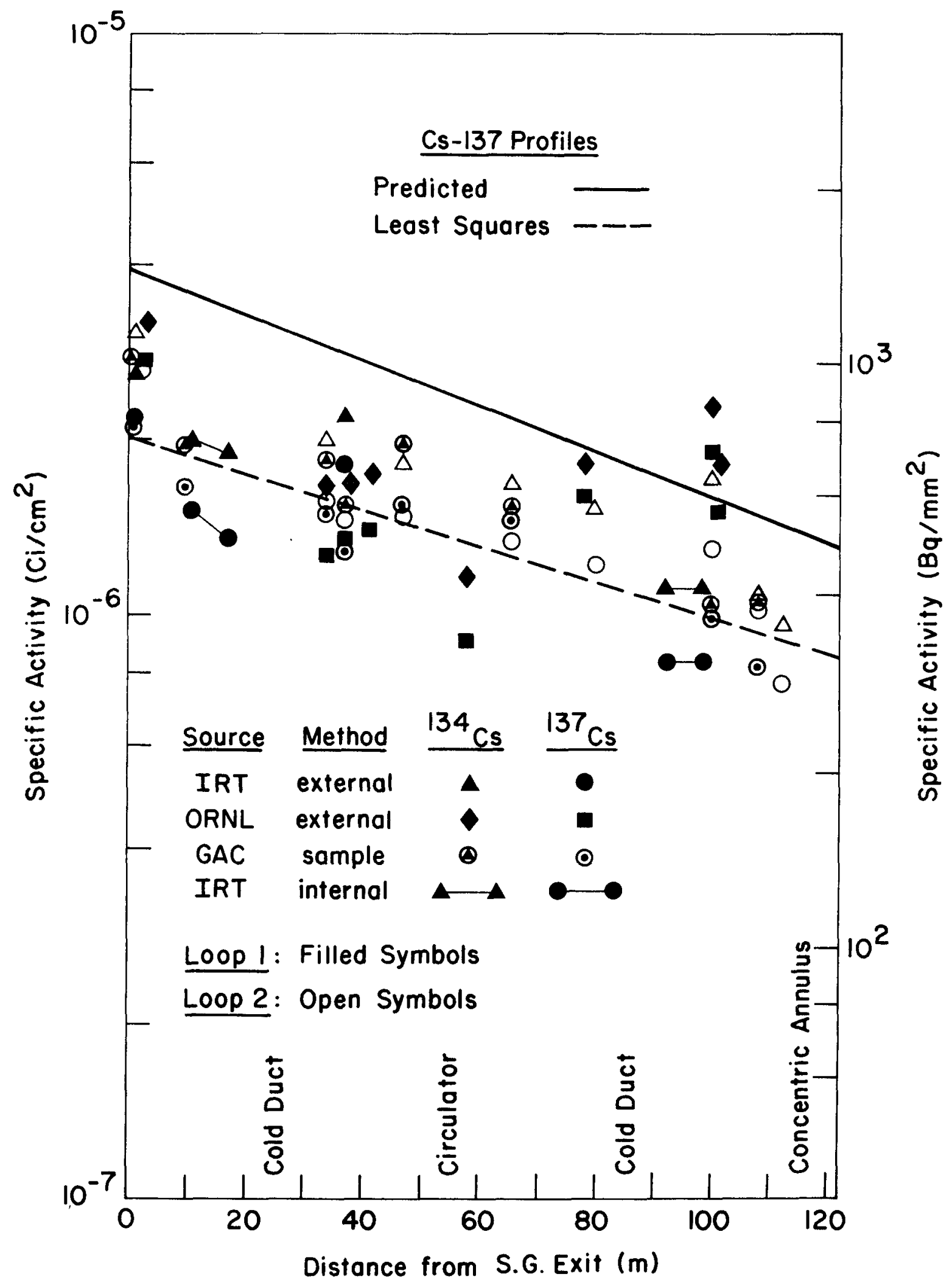

Fig. 6-9. Cesium deposition profiles in cold duct 


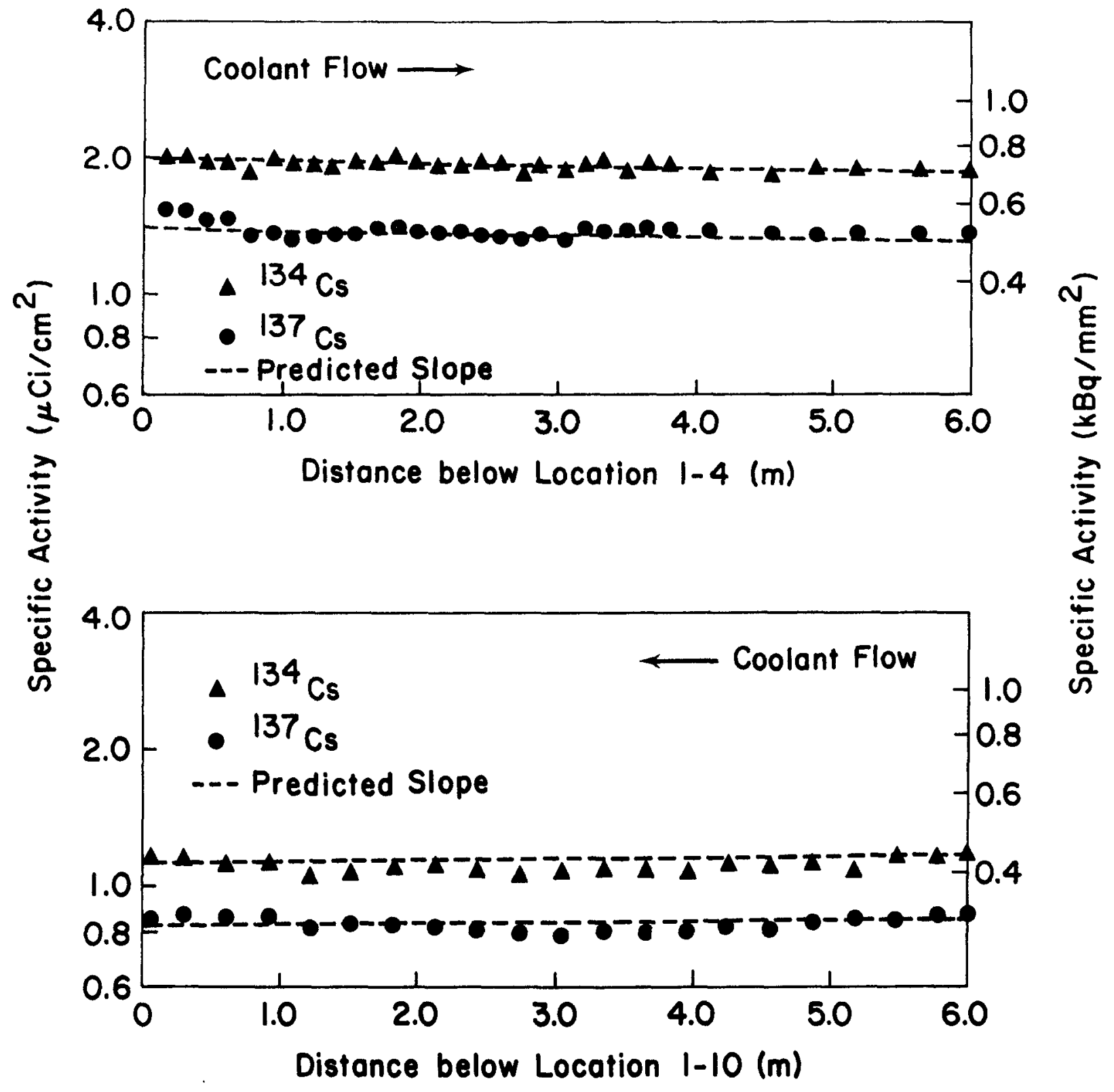

Fig. 6-10. Cesium profiles determined by internal duct scans 
The conclusions from the plateout design verifications may be summarized as follows:

1. Figure 6-8 indicates that the mass transfer control, or perfect sink, case (solid lines) resulted in good agreement everywhere except in the hot duct. It was concluded that the deposition process in the hot duct was limited by the high temperatures. By employing an appropriate sorption isotherm, it was shown that the plateout distribution in the hot duct could also be modeled.

2. The three data sets in Fig. 6-9 appear consistent, and the leastsquares line through the data is in good agreement with the cesium deposition profile predicted by the PAD code.

3. Very good agreement was found between predicted and measured cesium profiles determined by internal duct scans.

4. Since the cesium profiles in the tube bundle and cold duct have slopes consistent with PAD code predictions, most or all of the deposited cesium was transported in molecular form rather than on dust.

5. Overall, the agreement between the PAD code calculations and the in-situ gamma scans is remarkably good, indicating that the PAD code is an adequate empirical tool for predicting plateout distributions provided appropriate sorption isotherms are employed. This confirms the validity of the HTGR reference n.ethodology used to make such predictions.

Details of the code modifications necessary, the correlations performed, and the results obtained in this fission product plateout design verification study are presented in Refs. 15 and 16. 


\section{CONCLUSIONS}

The PBEOL Program provided a unique opportunity to verify HTGR design codes and assumptions in a representative HTGR environment over significant operating times. The program included verification of nuclear, thermal, and fission product design methods and confirmation of structural materials performance adequacy. The verifications employed the data from nondestructive testing at the reactor site, from laboratory examinations of samples removed from the primary circuit, and from a complementary program of driver fuel element PIEs at ORNL. The program was successfully completed in June 1978; the major conclusions are as follows:

1. Nuclear and thermal design methods verifications

a. Good agreement between determined and calculated axia1 and radial core power distributions, thorium absorption rate profiles, and core average burnup values confirmed the validity of HTGR nuclear design methods.

b. The thermal predictive accuracy of $\pm 87^{\circ} \mathrm{C}$ correlated directly with the determined nuclear predictive accuracy of $\pm 10 \%$.

c. Both nuclear and thermal predictive accuracies were well within the limits stated for other nuclear reactor systems.

2. Fission product design methods verifications

a. Core 2 gaseous release was accurately predicted, thereby verifying large HTGR fission gas release design methodology. 
b. Fission metal release and migration were not we11 predicted, indicating the need for better theoretical modeling of Peach Bottom fuel elements and more accurate materials properties data.

c. Very good modeling of observed fission product plateout distributions confirmed the validity of the HTGR reference methodology used for such predictions.

3. Materials performance verifications

a. The condition and metallurgical integrity of all components examined was excellent, with minimal coolant/substrate interaction and entirely acceptable residual mechanical properties.

b. The suitability of the materials used in the construction of the Peach Bottom HTGR was confirmed, thereby verifying the materials design methods used.

In summary, with the exception of fission metal release and transport modeling, where additional work is recommended, very good agreement between predicted and observed behavior in Peach Bottom has been demonstrated. This confirms the validity of the HTGR design methods employed for such nuclear, thermal, fission product, and materials applications. 


\section{REFERENCES}

1. Scheffel, W. J., N. L. Baldwin, and R. W. Tomlin, "Operating History Report for the Peach Bottom HTGR," Vols, I and II, ERDA Report GA-A13907, General Atomic Company, August 31, 1976.

2. Stouky, R. J., and E. J. Kohler, "Planned Decommissioning of the Peach Bottom Unit No. 1 HTGR," ASME Paper 73-WA/NE-7, November 1973.

3. "Decommissioning Peach Bottom Unit No. 1," Catalytic, Inc., Subcontract Final Report to Philadelphia Electric Company, July 1978.

4. Holzgraf, J. F., F. McCord, and C. F. Wallroth, "Gamma Spectroscopic Examination of Peach Bottom HTGR Core Components," DOE Report GA-A13453, Genera1 Atomic Company, Apri1 1978.

5. Hanson, D. L., N. L. Baldwin, and W. E. Selph, "Gamma Scanning the Primary Circuit of the Peach Bottom HTGR," General Atomic Report GA-A14161, October 31, 1976 (also ANS Transactions, November 1976).

6. Intelcom Rad Tech Corporation, "Measurement of Fission Product Activity in the Peach Bottom Reactor Primary Coolant Loop," ERDA Report GA-A14059, Genera1 Atomic Company, August 1976.

7. Catalytic, Incorporated, "Removal of Primary Circuit Components from the Peach Bottom HTGR," ERDA Report GA-A14369, General Atomic Company, April 1977.

8. Kohler, E. J., K. P. Steward, and J. V. Iacono, "Peach Bottom Decommissioning and Component Removal," General Atomic Report GA-A14297, August 1977.

9. Baldwin, N. L., B. L. Norman, and W. E. Be11, "Radi.schemica1 Examination of Peach Bottom HTGR Component Samples," DOE Report GA-A14495, General Atomic Company, to be published.

10. "Metallurgical Examination of Primary Circuit Components from the Peach Bottom HTGR," DOE Report GA-A14506, General Atomic Company, February 1978. 
11. Yang, L., W. A. Baugh, and N. L. Baldwin, "Study of Tritium Permeation Tests on Peach Bottom Steam Generator Tubes," ERDA Report GA-A14376, General Atomic Company, June 1977.

12. "Design Report for Peach Bottom Steam Generator," C. F. Braun \& Company, September 1961, Section A, p. 2.

13. Saurwein, J. J., and C. F. Wallroth, "HTGR Nuclear and Thermal Design Verification for the Peach Bottom HTGR," DOE Report GA-A14726, General Atomic Company, July 1978.

14. Wallroth, C. F., and J. J. Saurwein, "HTGR Nuclear and Thermal Design Verification in Peach Bottom" General Atomic Report GA-A14725, April 1978 (a1so ANS Transactions, June 1978).

15. Hanson, D. L., and N. L. Baldwin, "Fission Gas Release from Core 2 of the Peach Bottom HTGR," ANS Transactions, June 1978.

16. Hanson, D. L., D. E. Strong, and N. L. Baldwin, "Fission Product Design Verification in the Peach Bottom HTGR," DOE Report GA-A15022, General Atomic Company, to be published. 


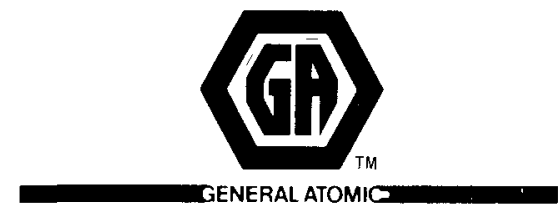

GENERAL ATOMIC COMPANY P. O. BOX 81608

SAN DIEGO, CALIFORNIA 92138 